SÉRGIO RAFAEL DEL GIOVANNINO JÚNIOR

\title{
INFLUÊNCIA DA SUBCORRENTE NORTE DO BRASIL, DO VENTO E DO APORTE FLUVIAL NA CIRCULAÇÃO EM TORNO DOS CÂNIONS DE JAPARATUBA E SÃO FRANCISCO
}

Dissertação apresentada ao Instituto Oceanográfico da Universidade de São Paulo, como parte dos requisitos para obtenção do título de Mestre em Ciências, Programa de Oceanografia, área de Oceanografia Física

Orientador:

Prof. Dr. Marcelo Dottori 


\title{
UNIVERSIDADE DE SÃO PAULO \\ INSTITUTO OCEANOGRÁFICO
}

\begin{abstract}
Influência da Subcorrente Norte do Brasil, do vento e do aporte fluvial na circulação em torno dos cânions de Japaratuba e São Francisco
\end{abstract}

Sérgio Rafael Del Giovannino Júnior

Dissertação apresentada ao Instituto Oceanográfico da Universidade de São Paulo, como parte dos requisitos para obtenção do título de Mestre em Ciências, Programa de Oceanografia, área de Oceanografia Física.

Julgada em

VERSÃO CORRIGIDA

\begin{tabular}{l}
\hline Prof. Dr. \\
\hline Prof. Dr. \\
\hline Prof. Dr.
\end{tabular}

\begin{tabular}{c}
\hline Conceito \\
\hline Conceito \\
\hline Conceito
\end{tabular}




\section{Resumo}

O presente trabalho visa descrever a circulação nos arredores dos cânions de Japaratuba e São Francisco, na plataforma continental da bacia de Sergipe e Alagoas, para compreender melhor os processos envolvendo o fluxo entre plataforma continental e oceano aberto. Para determinar e descrever essa circulação, foi implementado um modelo numérico hidrodinâmico, através do qual foi avaliada a influência dos cânions na circulação local e no fluxo de volume perpendicular à costa. Foi utilizado o campo médio mensal de temperatura e salinidade para março, julho e setembro de 2014 para gerar a subcorrente Norte do Brasil, em diferentes cenários de ventos constantes ou variáveis no tempo e ação do aporte fluvial característico da região.

O transporte perpendicular à costa no cânion de Japaratuba é predominantemente no sentido do cânion em direção ao oceano aberto, enquanto no cânion do São Francisco é predominantemente na direção oposta. Os ventos constantes de Nordeste e de Leste intensificaram os fluxos nessas direções, enquanto que ventos de Sudeste e Sul amenizaram os fluxos, e em determinadas situações causaram a inversão no sentido. A ação do aporte fluvial praticamente não causou alterações na circulação e no transporte na região.

Nas simulações com ventos variáveis no tempo e espaço, ventos entre Leste e Sudeste causaram transporte mais intenso nos cânion, vento de Sudeste causou transporte mais ameno no cânion de Japaratuba, e vento de Leste causou transporte mais ameno no cânion do São Francisco, em ambos os casos podendo inverter o sentido do fluxo.

Palavras chave: cânion de Japaratuba, cânion de São Francisco, circulação, vento, aporte fluvial, modelagem numérica. 


\section{Abstract}

This study aims to describe the circulation around Japaratuba and Sao Francisco submarine canyons on the continental shelf of the basin of Sergipe and Alagoas, to better understand the processes involving the flow between continental shelf and deep ocean. A numerical hydrodynamic model was implemented to determine and describe this circulation and evaluate canyons influence in local circulation and in the volume flow through the coast. The average monthly temperature and salinity field was used for march, july and september of 2014 to generate the Northern Brazilian Undercurrent, in different scenarios of constant and variable winds in time and river discharge contribution characteristic of the region.

The cross-shore transportation in Japaratuba canyon is predominantly in the direction of the canyon toward the open ocean, whereas in the San Francisco canyon it is predominantly in the opposite direction. The Northeast and East constant winds intensified flows in these directions, while the Southeast and South winds softened the flows, and in certain situations caused the reversal in direction. The river discharge contribution practically did not cause changes in the circulation and the transport in the region.

In the simulations with variable winds in time and space, winds between East and Southeast increased transport in the canyon, while Southeast wind decreased transport in the Japaratuba canyon, and East wind decreased transport in São Francisco canyon, both reversing the flow direction in some cases.

Keywords: Japaratuba submarine canyon, Sao Francisco submarine canyon, circulation, wind, river input, numerical modeling. 


\section{AGRADECIMENTOS}

O presente trabalho foi realizado com apoio da Coordenação de Aperfeiçoamento de Pessoal de Nível Superior - Brasil (CAPES) - Código de Financiamento 001.

Gostaria de agradecer a todos que contribuiram direta ou indiretamente para que esse trabalho fosse realizado e concluído.

Ao meu orientador Marcelo Dottori, que há tantos anos me orienta no laboratório, por sua paciência, ensinamento e ajuda.

Aos meus colegas de laboratório e aos outros colegas de mestrado e de graduação, que me auxiliaram ao longo desses anos, não só na Dissertação, mas também nas disciplinas, no trabalho de graduação, na realização de listas de exercícios, nas conversas durante o almoço. Agradecimento especial à Carine que me auxiliou muito com o modelo, e na adição das condições de contorno. Agradecimento especial também ao Thiago, cujo trabalho de mestrado dei continuação e me ajudou muito na época do trabalho de graduação.

Ao pessoal da secretaria de pós-graduação, por toda ajuda que me deram, pela colaboração, paciência e calma.

E por fim, não posso deixar de agradecer minha família por todo apoio, amor, paciência e parceria. Aos meus pais, minha irmã, meu irmão, e minhas duas sobrinhas, não tenho palavras para agradecer tudo que fizeram e fazem por mim. 


\section{LISTA DE FIGURAS}

Figura 1 - Área de estudo da Plataforma Continental Sergipe/Alagoas com as isóbatas de 50, 1000 e 2000 m, e as localizações dos cânions de Japaratuba e São Francisco. Figura extraída de Parente (2016).

Figura 2 - Distribuição da velocidade geostrófica para $10^{\circ} 30^{\prime}$ S. Valores positivos são para o Norte. Retângulo sombreado indica região de velocidade nula estimada. Figura extraída de Silveira et al. (1994).

Figura 3 - Localização da bacia do Rio São Francisco. Figura extraída de Silva \& Clarke (2004)

Figura 4 - Fluxo "along-slope" negativo (sup. esq.) e fluxo "along-slope" positivo (sup. dir.) para o Hemisfério Norte. Fluxo "along-slope" positivo (inf. dir.) e fluxo "along-slope" negativo (inf. esq.) para o Hemisfério Sul. Fluxo "along-slope" negativo privilegia ressurgência, enquanto fluxo "along-slope" positivo privilegia subsidência. Figura adaptada de Allen \& Madron (2009).

Figura 5 - Pontos de grade e batimetria utilizados no modelo

Figura 6 - Pontos de aporte fluvial, os rios São Francisco, Vaza Barris e Sergipe, e localização da plataforma PCM-9 e dos cânion de Japaratuba e do Sâo Francisco. Figura adaptada de Parente (2016).

Figura 7 - Rosa-dos-ventos da série temporal de 09/03/12 até 31/12/14, na plataforma de petróleo PCM-9.

Figura 8 - Cortes de seções verticais próximas aos cânions de Japaratuba e São Francisco: duas paralelas à costa, e três perpendiculares a costa, uma a Sul do cânion de Japaratuba, uma entre os cânions e a uma a Norte do cânion do São Francisco. 16

Figura 9 - Diagrama TS para os meses de março, julho e setembro, e respectivas massas d'água

Figura 10 - Diagrama TS do cruzeiro NEIII. Indica a presença de Água Tropical (TW), Água Central do Atlântico Sul (SACW) e Água Intermediária Antártica (AAIW). Retirado de Silveira et. al (1994).

Figura 11 - Circulação na área de estudo para março, sem vento, a 100, 200, 300 e 400 m.

Figura 12 - Circulação na área de estudo para julho, sem vento, a 100, 200, 300 e 400 m. .21 Figura 13 - Circulação na área de estudo para setembro, sem vento, nas profundidades 100, 200,300 e $400 \mathrm{~m}$. 
Figura 14 - Correntes nos meses de março, julho e setembro, sem vento, nas seções Sul, Central e Norte.

Figura 15 - Correntes nas seções do cânion de Japaratuba em março, julho e setembro, sem vento

Figura 16 - Correntes nas seções do cânion do São Francisco em março, julho e setembro, sem vento

Figura 17 - Transporte em função da profundidade nas seções dos cânions de Japaratuba e do São Francisco para os meses de março, julho e setembro, sem vento 25 Figura 18 - Batimetria da região em torno dos cânions, e direção dos fluxos predominantes, sendo positivos para o cânion de Japaratuba (esq.) e negativos para o cânion do São Francisco (dir.)

Figura 19 - Salinidade e temperatura nas seções dos cânions de Japaratuba e do São Francisco em março.

Figura 20 - Circulação na área de estudo para março e vento de Nordeste, a 100, 200, 300 e $400 \mathrm{~m}$.

Figura 21 - Circulação na área de estudo para março e ventos de Leste, a 100, 200, 300 e $400 \mathrm{~m}$.

Figura 22 - Circulação na área de estudo para março e ventos de Sudeste, a 100, 200, 300 e $400 \mathrm{~m}$.

Figura 23 - Circulação na área de estudo para março e vento de Sul, a 100, 200, 300 e 400 $m$.

Figura 24 - Energia cinética em função do tempo para o mês de março, nas condições sem vento, e com ventos de NE, E, SE e S.

Figura 25 - Corrente no mês de março para ventos de Nordeste, nas seções Sul, Central e Norte.

Figura 26 - Corrente no mês de março para ventos de Leste, nas seções Sul, Central e Norte.

Figura 27 - Corrente no mês de março para ventos de Sudeste, nas seções Sul, Central e Norte.

Figura 28 - Corrente no mês de março para ventos de Sul, nas seções Sul, Central e Norte.

Figura 29 - Correntes nas seções dos cânions de Japaratuba em março, nas condições sem vento $(A)$, vento de Nordeste $(B)$ e vento de Leste $(C)$.

Figura 30 - Correntes nas seções dos cânions de Japaratuba em março, nas condições sem vento $(A)$, vento de Sudeste $(B)$ e vetnto de Sul $(C)$. 
Figura 31 - Correntes nas seções do cânion do São Francisco em março, nos cenários sem vento $(A)$, vento de Nordeste $(B)$ e vento de Leste $(C)$.

Figura 32 - Correntes nas seções dos cânions do São Francisco em março, nos cenários sem vento $(A)$, vento de Sudeste $(B)$ e vento de Sul $(C)$.

Figura 33 - Transporte em função da profundidade nas seções dos cânions de Japaratuba e São Francisco para o mês de março para as condições de vento de Nordeste, Leste,

Sudeste e Sul.

Figura 34 - Salinidade e temperatura nas seções dos cânions de Japaratuba e do São Francisco em julho.

Figura 35 - Circulação na área de estudo para julho e vento de Nordeste, a 100, 200, 300 e $400 \mathrm{~m}$.

Figura 36 - Circulação na área de estudo para julho e vento de Leste, a 100, 200, 300 e 400 $\mathrm{m}$.

Figura 37 - Circulação na área de estudo para julho e vento de Sudeste, a 100, 200, 300 e $400 \mathrm{~m}$.

Figura 38 - Circulação na área de estudo para julho e vento de Sul, a 100, 200, 300 e 400 m.

Figura 39 - Energia cinética em função do tempo para o mês de julho, nas condições sem vento,e com ventos de NE, E, SE e S.

Figura 40 - Corrente no mês de julho para ventos de Nordeste, nas seções Sul, Central e Norte.

Figura 41 - Corrente no mês de julho para ventos de Leste nas seções Sul, Central e Norte.

Figura 42 - Corrente no mês de julho para ventos de Sudeste, nas seções Sul, Central e Norte.

Figura 43 - Corrente no mês de julho para ventos de Sul nas seções Sul, Central e Norte. .42 Figura 44 - Correntes nas seções do cânion de Japaratuba em julho, nos cenários sem vento $(A)$, vento de Nordeste $(B)$ e vento de Leste $(C)$.

Figura 45 - Correntes nas seções do cânion de Japaratuba em julho, nos cenários sem vento $(A)$, vento de Sudeste $(B)$ e vento de Leste $(C)$.

Figura 46 - Correntes na seção do cânion do São Francisco em julho, nos cenários sem vento $(A)$, vento de Nordeste $(B)$ e vento de Leste $(C)$.

Figura 47 - Correntes nas seção do cânion do São Francisco em julho, nos cenários sem vento $(A)$, vento de Sudeste $(B)$ e vento de Sul (C). 
Figura 48 - Transporte em função da profundidade nas seções dos cânions de Japaratuba e São Francisco para o mês de julho para as condições de vento de Nordeste, Leste, Sudeste, Sul e sem vento.

Figura 49 - Salinidade e temperatura nas seções dos cânions de Japaratuba e do São Francisco para o mês de setembro.

Figura 50 - Circulação na área de estudo para setembro e vento de Nordeste, a 100, 200, 300 e $400 \mathrm{~m}$.

Figura 51 - Circulação na área de estudo para setembro e vento de Leste, a 100, 200, 300 e $400 \mathrm{~m}$.

Figura 52 - Circulação na área de estudo para setembro e vento de Sudeste, a 100, 200, 300 e $400 \mathrm{~m}$. .50

Figura 53 - Circulação na área de estudo para setembro e vento de Sul, a 100, 200, 300 e $400 \mathrm{~m}$.

Figura 54 - Energia cinética em função do tempo para o mês de setembro, nas condições sem vento, com ventos de NE, E, SE e S.

Figura 55 - Corrente no mês de setembro para ventos de Nordeste, nas seções Sul, Central e Norte.

Figura 56 - Corrente no mês de setembro para ventos de Leste, nas seções Sul, Central e Norte.

Figura 57 - Corrente no mês de setembro para ventos de Sudeste, nas seções Sul, Central e Norte.

Figura 58 - Corrente no mês de setembro para ventos de Sul, nas seções Sul, Central e Norte.

Figura 59 - Correntes nas seções do cânion de Japaratuba em setembro, nos cenários sem vento $(A)$, vento de Nordeste $(B)$ e vento de Leste $(C)$.

Figura 60 - Correntes nas seções do cânion de Japaratuba em setembro,nos cenários sem vento $(A)$, vento de Sudeste $(B)$ e vento de Sul (C).

Figura 61 - Correntes nas seções do cânion do São Francisco em setembro, nos cenários sem vento $(A)$, vento de Nordeste $(B)$ e vento de Leste $(C)$.

Figura 62 - Correntes nas seções do cânion do São Francisco em setembro, nos cenários sem vento $(A)$, vento de Sudeste $(B)$ e vento de Sul $(C)$.

Figura 63 - Transporte em função da profundidade nas seções dos cânions de Japaratuba e São Francisco para o mês de setembro para as condições de vento de Nordeste, Leste, Sudeste, Sul e sem vento.

Figura 64 - Salinidade e temperatura nas seções dos cânions de Japaratuba e do São Francisco para o mês de março com aporte fluvial e sem vento. 
Figura 65 - Salinidade e temperatura nas seções dos cânions de Japaratuba e do São

Francisco para o mês de março sem aporte fluvial e sem vento.

Figura 66 - Energia cinética em função do tempo para o mês de março, com e sem aporte fluvial e sem vento

Figura 67 - Corrente no mês de março com e sem aporte fluvial e sem vento, nas seções

Sul, Central e Norte.

Figura 68 - Correntes nas seções dos cânions de Japaratuba e do São Francisco para o mês de março com e sem aporte fluvial e sem vento.

Figura 69 - Transporte em função da profundidade nas seções dos cânions de Japaratuba e

São Francisco para o mês de março para as condições com e sem aporte fluvial.

Figura 70 - Salinidade e temperatura nas seções dos cânions de Japaratuba e do São

Francisco para o mês de julho com aporte fluvial e sem vento.

Figura 71 - Salinidade e temperatura nas seções dos cânions de Japaratuba e do São

Francisco para o mês de julho sem aporte fluvial e sem vento.

Figura 72 - Corrente no mês de Julho com e sem aporte fluvial e sem vento, nas seções Sul, Central e Norte.

Figura 73 - Correntes nas seções dos cânions de Japaratuba e do São Francisco para o mês de julho com e sem aporte fluvial e sem vento.

Figura 74 - Transporte em função da profundidade nas seções dos cânions de Japaratuba e São Francisco para o mês julho para as condições com e sem aporte fluvial.

Figura 75 - Salinidade e temperatura nas seções dos cânions de Japaratuba e do São

Francisco para o mês de setembro com aporte fluvial e sem vento.

Figura 76 - Salinidade e temperatura nas seções dos cânions de Japaratuba e do São

Francisco para o mês de setembro sem aporte fluvial e sem vento.

Figura 77 - Corrente no mês de setembro com e sem aporte fluvial e sem vento, nas seções

Sul, Central e Norte.

Figura 78 - Correntes nas seções dos cânions de Japaratuba e do São Francisco para o mês de setembro com e sem aporte fluvial e sem vento.

Figura 79 - Transporte em função da profundidade nas seções dos cânions de Japaratuba e São Francisco para o mês de setembro para as condições com e sem aporte fluvial. .70 Figura 80 - Ângulo de incidência e intensidade do vento médio, e transporte na seção dos cânions de Japaratuba e São Francisco para o mês de março. As linhas pontilhadas indicam a média no período.

Figura 81 - Ângulo de incidência e intensidade do vento médio, e transporte na seção dos cânions de Japaratuba e São Francisco para o mês de julho. As linhas pontilhadas indicam a média no período. 
Figura 82 - Ângulo de incidência e intensidade do vento médio, e transporte na seção dos cânions de Japaratuba e São Francisco para o mês de setembro. As linhas pontilhadas indicam a média no período.

Figura 83 - Condições de vento entre Leste e Sudeste, relacionados com transportes máximo e mínimos para os cânions de Japaratuba (JAP) e do São Francisco (SFR), sendo positivo (+) para o cânion de Japaratuba, e negativo (-) para o cânion do São Francisco. ...84 Figura 84 - Diferentes cenários para a SNB e correntes na PC e seus respectivos efeitos nos cânions de Japaratuba e do São Francisco 86

\section{LISTA DE TABELAS}

Tabela 1 - Vazão fluvial considerada no modelo para os rios São Francisco, Vaza Barris e Sergipe. Dados do INMET para julho de 2014.

Tabela 2 - Condições de vento, aporte fluvial e campo de T e S utilizadas em cada simulação. Modo diagnóstico indica T e S constantes no tempo, enquanto o modo prognóstico permite variação de T e S.

Tabela 3 - Fluxo de volume $\left(\times 10^{6} \mathrm{~m}^{3} / \mathrm{s}\right)$ através da seção dos cânions em diferentes cenários de vento e aporte fluvial. Valores positivos indicam fluxo dos cânions em direção ao oceano aberto, e valores negativos indicam fluxo do oceano aberto em direção aos cânions. ID é a identificação de cada uma das simulações. 


\section{LISTA DE SIGLAS E ABREVIATURAS}

\begin{tabular}{|c|c|}
\hline ACAS & - Água Central do Atlântico Sul \\
\hline AIA & - Água Intermediária Antártica \\
\hline AT & - Água Tropical \\
\hline CB & - Corrente do Brasil \\
\hline CNB & - Corrente Norte do Brasil \\
\hline CSE & - Corrente Sul Equatorial \\
\hline $\mathrm{cm}$ & - Centímetro \\
\hline DHN & - Diretoria de Hidrografia e Navegação \\
\hline dir. & - Direita \\
\hline ECOM & - Estuarine and Coastal Ocean Hydrodynamic Model \\
\hline esq. & - Esquerda \\
\hline inf. esq., inf. dir. & - inferior esquerda, inferior direita \\
\hline int. & - Intensidade \\
\hline 10 & - Instituto Oceanográfico \\
\hline IOUSP & - Instituto Oceanográfico da Universidade de São Paulo \\
\hline $\mathrm{km}$ & - Quilômetros \\
\hline LHiCo & - Laboratório de Hidrodinâmica Costeira \\
\hline $\mathrm{m}$ & - Metros \\
\hline NCEP & - National Centers for Environmental Prediction \\
\hline$N, S, E, W$ & - Norte, Sul, Leste, Oeste \\
\hline NE, NW, SE, SW & - Nordeste, Noroeste, Sudeste, Sudoeste \\
\hline PCR-SEAL & - Projeto de Caracterização Regional da bacia Sergipe-Alagoas \\
\hline PC & - Plataforma continental \\
\hline PCSEAL & - Plataforma continental de Sergipe e Alagoas \\
\hline POM & - Princeton Ocean Model \\
\hline prof. & - Profundidade \\
\hline Q & - Transporte de volume $\left(\mathrm{m}^{3} / \mathrm{s}\right)$ \\
\hline$S$ & - Salinidade \\
\hline s & - Segundo \\
\hline SNB & - Subcorrente Norte do Brasil \\
\hline sup. esq., sup. dir. & - superior esquerda, superior direita \\
\hline Sv & - Sverdrup \\
\hline$T$ & - Temperatura \\
\hline $\mathrm{v}$ & - Velocidade horizontal \\
\hline w & - Velocidade vertical \\
\hline
\end{tabular}




\section{Sumário}

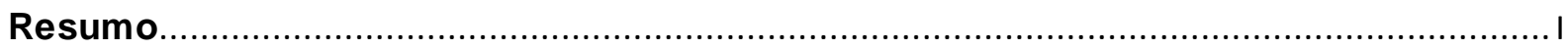

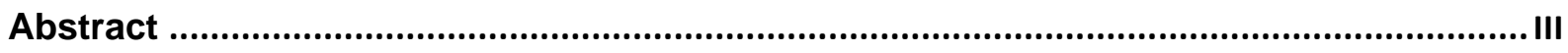

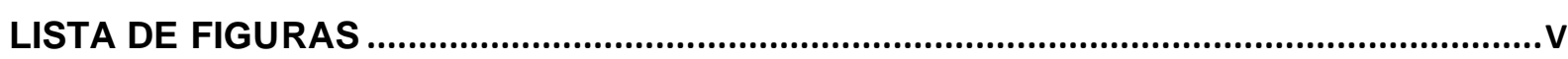

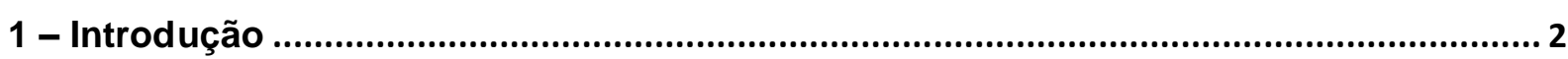

1.1 - Área de estudo e circulação oceânica ................................................................ 2

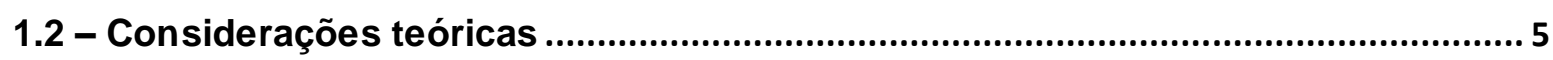

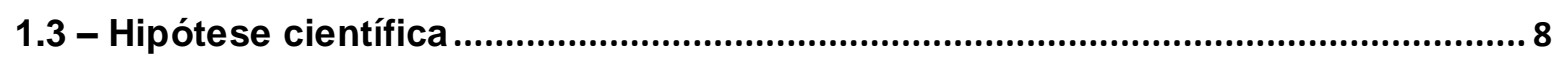

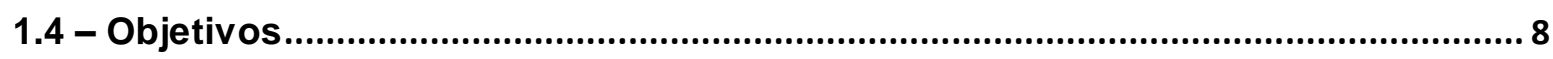

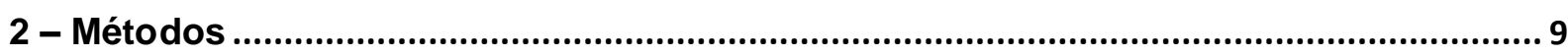

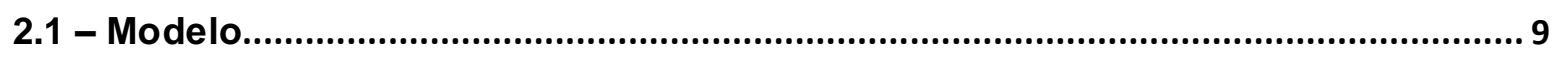

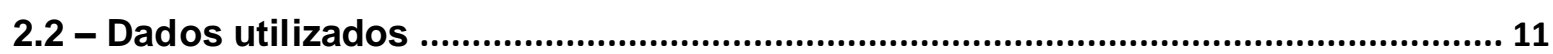

2.3 - Tratamento dos dados e cenários utilizados no modelo.................................... 13

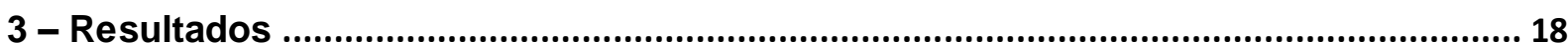

3.1 - Forçantes: Campo de $T$ e $S$ (SNB) e vento (sem aporte fluvial)......................... 18

3.1.1 - Cenários sem vento $(A)$............................................................................... 19

3.1.2 - Março: Cenários com ventos de Nordeste, Leste, Sudeste e Sul (B) .......... 26

3.1.3 - Julho: Cenários com ventos de Nordeste, Leste, Sudeste e Sul (B) ............ 37

3.1.4 - Setembro: Cenários com ventos de Nordeste, Leste, Sudeste e Sul (B) .... 48

3.2 - Forçantes: Campo de Te Se Aporte fluvial (C e D), sem vento.......................... 59

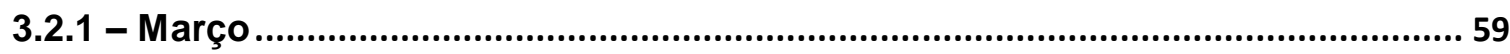

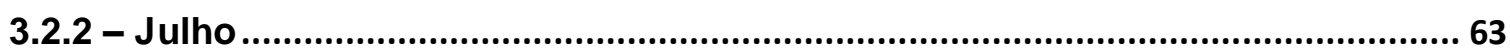

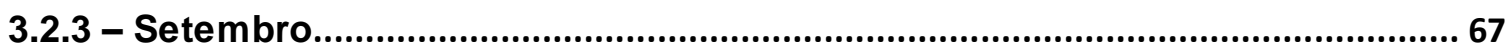

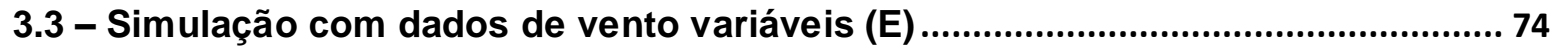

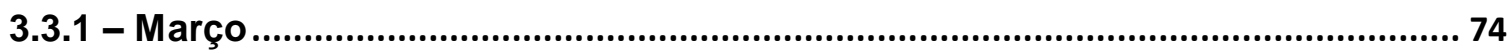

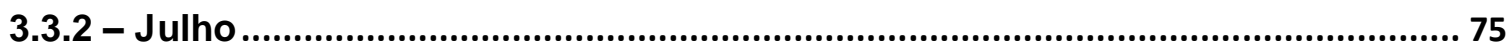

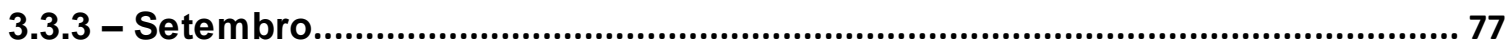

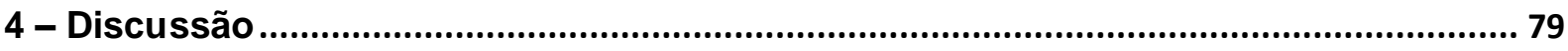

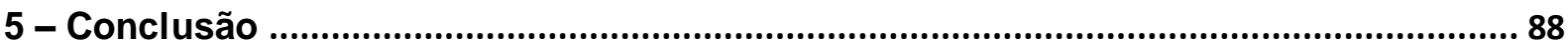




\section{1 - Introdução}

\section{1 - Área de estudo e circulação oceânica}

A plataforma continental de Sergipe e Alagoas (PCSEAL) se estende por cerca de $370 \mathrm{~km}$, com uma orientação de aproximadamente $40^{\circ}$ no sentido horário em relação ao Norte geográfico, entre as latitudes $9^{\circ} \mathrm{S}$ e $11^{\circ} 30^{\prime} \mathrm{S}$, na margem continental do nordeste do Brasil (Figura 1). É considerada uma plataforma estreita, com largura variando de $42 \mathrm{~km}$, em frente à Maceió, à $18 \mathrm{~km}$ na região sul. A plataforma praticamente não ultrapassa os $50 \mathrm{~m}$ de profundidade, havendo um destaque pela presença dos cânions do São Francisco e o de Japaratuba, cortando a plataforma e o talude na região. O cânion do São Francisco apresenta $11 \mathrm{~km}$ de largura e $700 \mathrm{~m}$ de profundidade, enquanto que o cânion de Japaratuba apresenta $21 \mathrm{~km}$ de largura e atinge $1400 \mathrm{~m}$ de profundidade (Coutinho, 1976; Summerhayes et al., 1976).

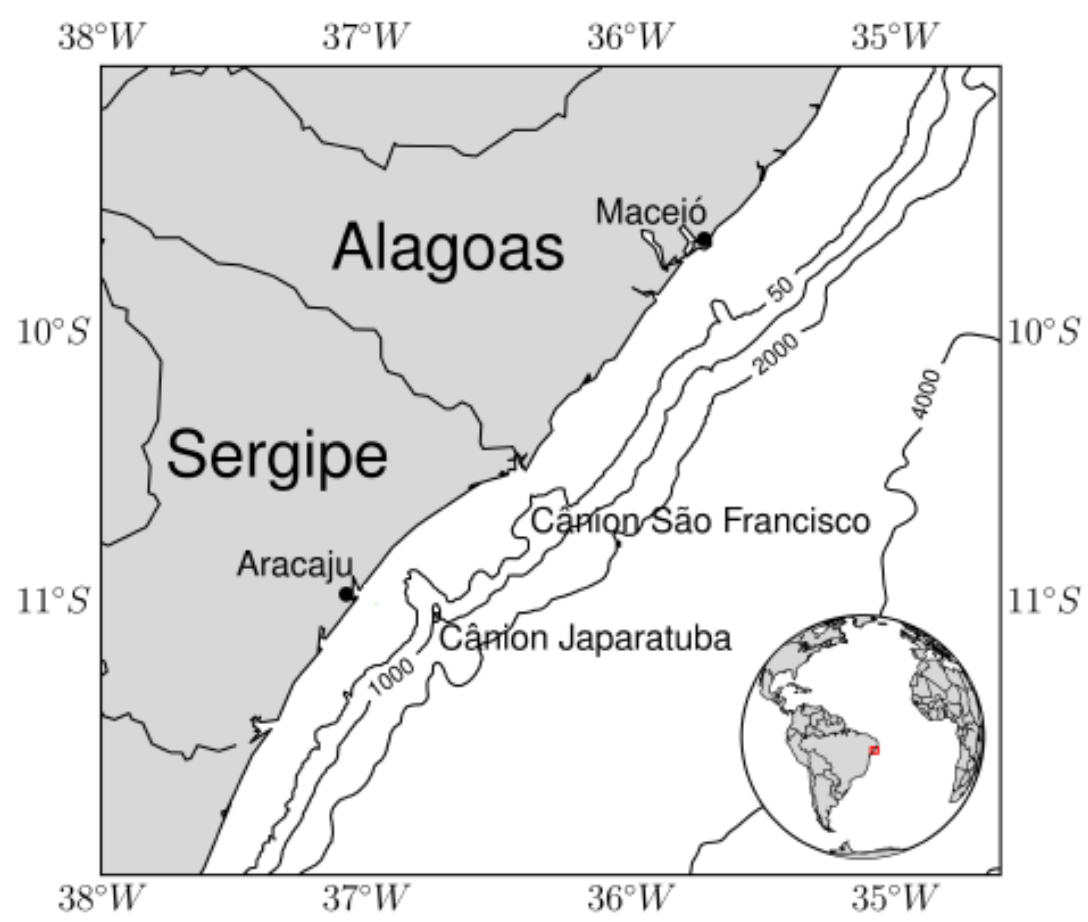

Figura 1 - Área de estudo da Plataforma Continental Sergipe/Alagoas com as isóbatas de 50, 1000 e $2000 \mathrm{~m}$, e as localizações dos cânions de Japaratuba e São Francisco. Figura extraída de Parente (2016). 
Na região da bacia de Sergipe e Alagoas há poucos trabalhos descrevendo aspectos dinâmicos da sua plataforma continental. Mais comum, entretanto, são descrições mais detalhadas da região do talude e do oceano aberto como, por exemplo, os trabalhos de Silveira et al. (1994), Goes et al. (2005) e Soutelino (2005).

A Corrente Sul Equatorial (CSE) flui na direção oeste e ao se aproximar da costa brasileira, ao longo do talude da bacia de Sergipe e Alagoas, bifurca em torno de $15^{\circ} \mathrm{S}$, alimentando a Corrente Norte do Brasil (CNB), que flui na direção Norte, e a Corrente do Brasil (CB), que flui na direção Sul (Stramma, 1991).

A CSE é dividida em 3 componentes, chamadas de ramo Norte, ramo Central e ramo Sul. O limite entre os ramos central e sul da CSE se dá entre as latitudes $7^{\circ}$ S e 9oS (Molinari, 1982; Peterson \& Stramma, 1991; Stramma, 1991).

Silveira et al. (1994) analisaram dados hidrográficos entre as latitudes $4^{\circ} \mathrm{S}$ e $10^{\circ} 30^{\prime} S$ na costa Nordeste do Brasil, sendo o primeiro trabalho a observar a Subcorrente Norte do Brasil (SNB). Nos transectos perpendiculares à costa foram observados núcleos de velocidade da SNB entre 100 e 200 metros de profundidade (Figura 2).

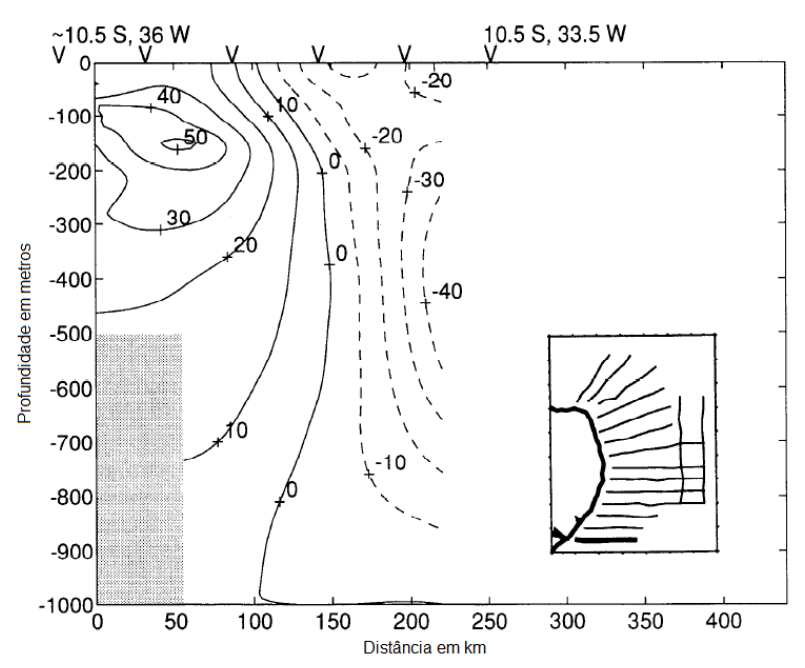

Figura 2 - Distribuição da velocidade geostrófica para 10³0'S. Valores positivos são para o Norte. Retângulo sombreado indica região de velocidade nula estimada. Figura extraída de Silveira et al. (1994).

Em um dos transectos analisados por Silveira et al. (1994), à $10^{\circ} 30^{\prime} \mathrm{S}$, é observada a SNB como uma corrente forte para Norte transportando $23,7 \mathrm{~Sv}$, com núcleo em sub-superfície de $50 \mathrm{~cm} \cdot \mathrm{s}^{-1}$, a cerca de 150 metros de profundidade (Figura 2). Também há um forte fluxo para Sul transportando $22,5 \mathrm{~Sv}$, à leste da SNB. Esse fluxo para Sul foi observado apenas em dois transectos (Figura 2), em 
$10^{\circ} 30^{\prime}$ 'S e $10^{\circ} \mathrm{S}$, e é parte do meandramento do ramo Sul da CSE. Entre as latitudes $10^{\circ} 30^{\prime} \mathrm{S}$ e $7^{\circ} \mathrm{S}$, a SNB apresentou um transporte médio de $20 \mathrm{~Sv}$, sendo $18 \mathrm{~Sv}$ confinados entre a superfície e 500 metros de profundidade.

Stramma et al. (1995) encontraram velocidades maiores, de $80 \mathrm{~cm} \cdot \mathrm{s}^{-1}$ no núcleo em 5030'S, o que pode indicar que nesta latitude o ramo central da CSE já se encontra unida à SNB formando a CNB.

Além deste complexo sistema de correntes na região, há a presença de dois cânions, conforme já antecipado. Desta forma, a presença dos cânions de Japaratuba e o de São Francisco podem provocar alterações na dinâmica local e incrementar o fluxo de volume entre a plataforma continental e o oceano aberto.

Por exemplo, Hamilton el al. (2015) concluíram, através de simulação numérica, que no cânion De Soto, no Golfo do México, há um transporte de massa cruzando as isóbatas nos dois sentidos, com exportação de regiões mais profundas para o cânion maior que a importação.

Ahumada-Sempoal et al. (2015) estudaram o transporte de água e partículas no cânion de Balnes (Mar Mediterrâneo), através de simulação climatológica, e concluíram que a exportação da plataforma para o talude é 3 vezes maior que a importação, e o transporte ao longo das isóbatas é de uma ordem de grandeza maior na região do cânion do que em regiões adjacentes.

Skliris et al. (2002) realizaram simulações para o cânion de Calvi, na região de Córsega (Mar Mediterrâneo), para diversos regimes de estratificação e padrões de vento. Estes autores concluíram que o transporte ao longo do cânion é reduzido em condições de maior estratificação e que o vento influencia fortemente nesse transporte perpendicular à costa.

Rennie et al. (2009) mostraram, através de simulações numéricas no cânion de Perth (Austrália), que há formação recorrente de vórtices ciclônicos e anticiclônicos dentro do cânion e que a ressurgência dentro do cânion foi mais intensa do que em qualquer outro local da plataforma continental.

A presente região de estudo também apresenta como destaque a presença do Rio São Francisco, que possui extensão de $2.700 \mathrm{~km}$ e cuja bacia possui uma área de $645.000 \mathrm{~km}^{2}$ (Figura 3). A foz do Rio São Francisco ocorre no Oceano Atlântico, entre os estados de Sergipe e Alagoas (Silva \& Clarke, 2004), estando a aproximadamente 66 km de distância da cabeceira do cânion de Japaratuba. 


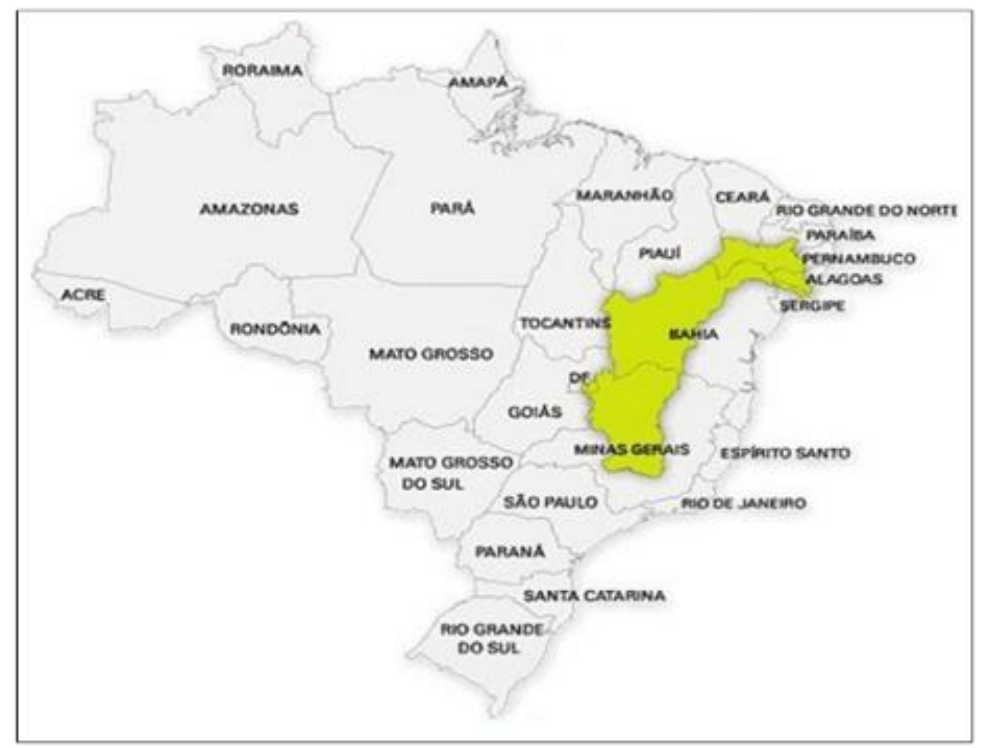

Figura 3- Localização da bacia do Rio São Francisco. Figura extraída de Silva \& Clarke (2004).

\section{2 - Considerações teóricas}

Em regiões de plataforma continental, as correntes são predominantemente paralelas à costa. Por apresentarem equilíbrio geostrófico (balanço entre força do gradiente de pressão e força de Coriolis), elas tendem a seguir isóbatas, sendo capazes de acompanhar variações suaves de batimetria. Isto impede que haja grandes fluxos perpendiculares à costa, entre a plataforma continental e o oceano profundo (Freeland \& Denman, 1982; Sobarzo et al., 2001; Skliris et al., 2002; Song \& Chao, 2004).

Quando as correntes se aproximam de cânions estreitos (com largura menor que o raio interno de Rossby), o fluxo cruza isóbatas e a coluna se estica, alterando a vorticidade. Nesta situação, a superfície livre do oceano se inclina e produz um gradiente de pressão no cânion, o que induz fluxo de água ao longo de seu eixo. Dessa forma, o gradiente de pressão no cânion não é balanceado pela força de Coriolis e a circulação não é mais geostrófica (Freeland \& Denman, 1982; Klinck 1988, 1996; Allen, 1996; She \& Klinck, 2000).

Ao deixar de ser geostrófica, a circulação apresenta aceleração, que só pode ser balanceada pelo atrito e causará fluxos perpendiculares à costa ao longo do eixo do cânion, através de subsidência ou ressurgência (Freeland \& Denman, 1982; Allen et al., 2001). Assim, a topografia dos cânions submarinos os torna vias preferenciais de transporte entre plataforma continental e oceano profundo. Cânions também 
afetam a circulação e as condições de hidrodinâmica local, além de serem regiões que podem aumentar a produtividade (Madron, 1994; Bosley et al., 2004; Skliris et al., 2004; Rennie et al., 2009).

Dados in situ, experimentos em laboratórios e resultados de modelos numéricos sugerem que o sentido das correntes paralelas à costa influencia se o cânion privilegia condições de ressurgência ou subsidência (Freedland \& Denman, 1982; Hickey et al., 1986; Klinck, 1988, 1996; She \& Klinck, 2000; Skliris et al., 2002; Bosley et al., 2004; Jordi 2005; Palanques, et al., 2005; Rennie et al., 2009). Uma vez que as direções dos ventos podem afetar a direção das correntes, ventos fortes podem aumentar condições de trocas na direção perpendicular à costa.

Seguindo a convenção de Allen \& Madron (2009), fluxos na direção ao longo da plataforma/talude, que sejam na mesma direção de propagação das ondas de Kelvin, serão chamados de fluxos "along-slope" positivos (Figura 4 sup. dir. e Figura 4 inf. dir.), e fluxos na direção oposta serão chamadas de fluxos "along-slope" negativos (Figura 4 sup. esq. e Figura 4 inf. esq.).

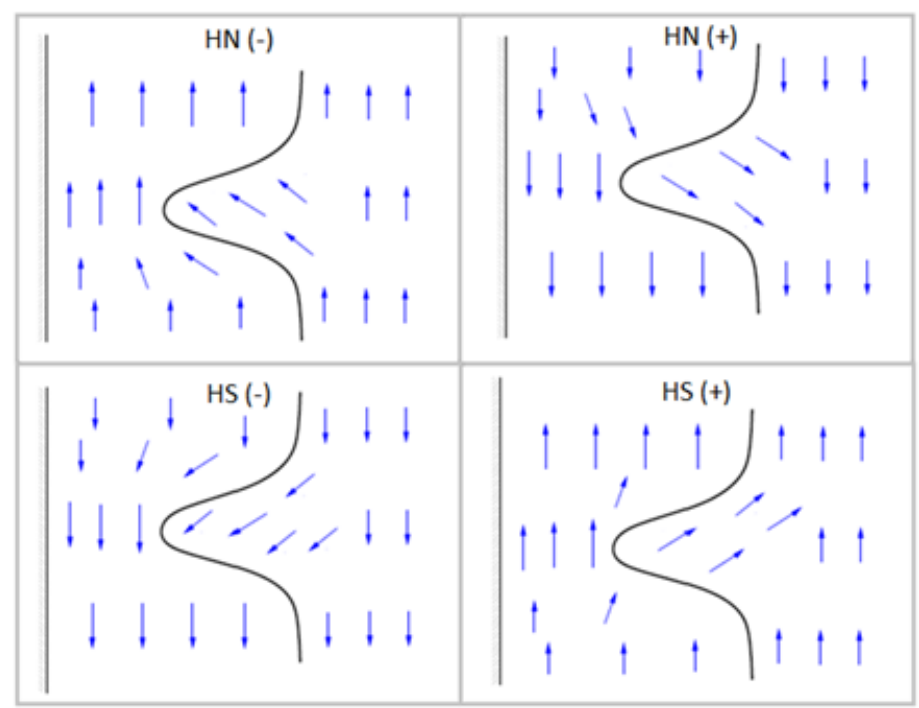

Figura 4 - Fluxo "along-slope" negativo (sup. esq.) e fluxo "along-slope" positivo (sup. dir.) para o Hemisfério Norte. Fluxo "along-slope" positivo (inf. dir.) e fluxo "along-slope" negativo (inf. esq.) para o Hemisfério Sul. Fluxo "along-slope" negativo privilegia ressurgência, enquanto fluxo "along-slope" positivo privilegia subsidência. Figura adaptada de Allen \& Madron (2009). 
Geralmente fluxos "along-slope" negativos são associados com ressurgência (fluxo ascendente e em direção à costa), enquanto fluxos "along-slope" positivos são associados com subsidência (fluxo descendente e em direção ao oceano) (Klinck, 1996; Hickey, 1997; Ardhuin et al., 1999; She \& Klinck, 2000; Allen et al., 2001; Allen \& Madron, 2009).

Diversos estudos coincidem com esse padrão, como os realizados nos cânions de Grand-Rhône (França) (Madron, 1994), Blanes (Espanha) (Granata et al., 1999), Barkley (EUA) (Allen, 2001), Biobío (Chile) (Sobarzo et al., 2001), Calvi (França) (Skliris et al., 2002), Astoria (EUA) (Bosley, 2004) e Palamós (Espanha) (Jordi et al., 2005), e nos cânions simulados de Astoria (EUA) (Hickey, 1997; She \& Klinck, 2000), Blanes (Espanha) (Ardhuin et al., 1999; Allen et al., 2001), Calvi (França) (Skliris et al., 2004) e Perth (Austrália) (Rennie et al., 2009).

Dessa forma, podemos dizer que, para o Hemisfério Sul, fluxos com a costa à sua esquerda (fluxos "along-slope" positivos) favorecem subsidência, enquanto fluxos com a costa à sua direita (fluxos "along-slope" negativos) privilegiam ressurgência. 


\section{3 - Hipótese científica}

A hipótese científica deste trabalho é que a topografia (especificamente a presença dos Cânions de Japaratuba e do São Francisco) afeta a circulação da região e também o fluxo de volume entre o oceano aberto e a plataforma continental.

\section{4 - Objetivos}

Para responder a hipótese científica, o presente trabalho tem como objetivo principal:

- Descrever a circulação na região de estudo e nos cânions de Japaratuba e do São Francisco em diferentes condições de ventos e aporte fluvial e avaliar a influência da Subcorrente Norte do Brasil.

Como objetivos específicos, este trabalho pretende:

- Estimar o fluxo de volume nos cânions em diferentes condições de ventos.

- Estimar o fluxo de volume nos cânions na presença de descargas fluviais.

- Determinar quais configurações favorecem ressurgência ou subsidência nos cânions de Japaratuba e do São Francisco. 


\section{2 - Métodos}

\section{1 - Modelo}

O modelo hidrodinâmico de equações primitivas ECOM (Estuarine and Coastal Ocean Hydrodynamic Model) foi utilizado neste trabalho, no módulo ECOMSED de águas rasas, sendo uma variante do Princeton Ocean Model (POM) (Blumberg \& Mellor, 1987; Blumberg et al., 1999). Este é um modelo numérico 3D de superfície livre, que utiliza uma grade $\mathrm{C}$ de Arakawa e coordenadas verticais sigma (Manual do usuário sECOM, 2010) para discretizar o sistema de equações primitivas. O conjunto de equações que o modelo resolve envolve conservação de momento, massa, calor e sal, em função dos termos de velocidade $U i=(\mathrm{U}, \mathrm{V}, \mathrm{W})$, temperatura $(T)$ e salinidade $(U)$, dado respectivamente por:

$$
\frac{\partial U_{i}}{\partial x_{i}}=0
$$

$$
\begin{gathered}
\frac{\partial}{\partial t}(U, V)+\frac{\partial}{\partial x_{i}}\left[U_{i}(U, V)\right]+f(-V, U)=-\frac{1}{\rho_{0}}\left(\frac{\partial P}{\partial x}, \frac{\partial P}{\partial y}\right)+\frac{\partial}{\partial z}\left[K_{M} \frac{\partial}{\partial z}(U, V)\right]+\left(F_{U}, F_{V}\right) \\
\frac{\partial T}{\partial t}+\frac{\partial}{\partial x_{i}}\left(U_{i} T\right)=\frac{\partial}{\partial z}\left(K_{H} \frac{\partial T}{\partial z}\right)+F_{T} \\
\frac{\partial S}{\partial t}+\frac{\partial}{\partial x_{i}}\left(U_{i} S\right)=\frac{\partial}{\partial z}\left(K_{H} \frac{\partial S}{\partial z}\right)+F_{S}
\end{gathered}
$$


Sendo $P$ a pressão, $f$ o parâmetro de Coriolis, $\mathrm{Km}$ e Kh são coeficientes de mistura. Também é considerado pelo modelo o balanço hidrostático dado por:

$$
\begin{gathered}
\frac{P}{\rho_{0}}=g(\eta-z)+\int_{z}^{\eta} g \frac{\rho^{\prime}-\rho_{0}}{\rho_{0}} d z^{\prime} . \\
\rho=\rho_{0}+\rho^{\prime}
\end{gathered}
$$

Onde $\eta(x, y, t)$ é o nível do mar, $\rho$ é a densidade local e $\rho_{0}$ é a densidade de referência, sendo a densidade local função de T e $S$.

Com relação aos dados inseridos no modelo, a malha utilizada (Figura 5) foi de 50 (perpendicular à costa) por 150 (paralelo à costa) pontos, com 53 níveis sigma irregularmente espaçados, variando de 0,01 (até o nível 19) a 0,025 (nos níveis mais profundos). A resolução horizontal utilizada é de cerca de $2 \mathrm{~km}$, sendo de 2,1 km na direção perpendicular à costa, e de 2,7 km na direção paralela à costa, entre as latitudes $9^{\circ} \mathrm{S}$ e $12,2^{\circ} \mathrm{S}$, e entre as longitudes $34,6^{\circ} \mathrm{W}$ e $37,5^{\circ} \mathrm{W}$.

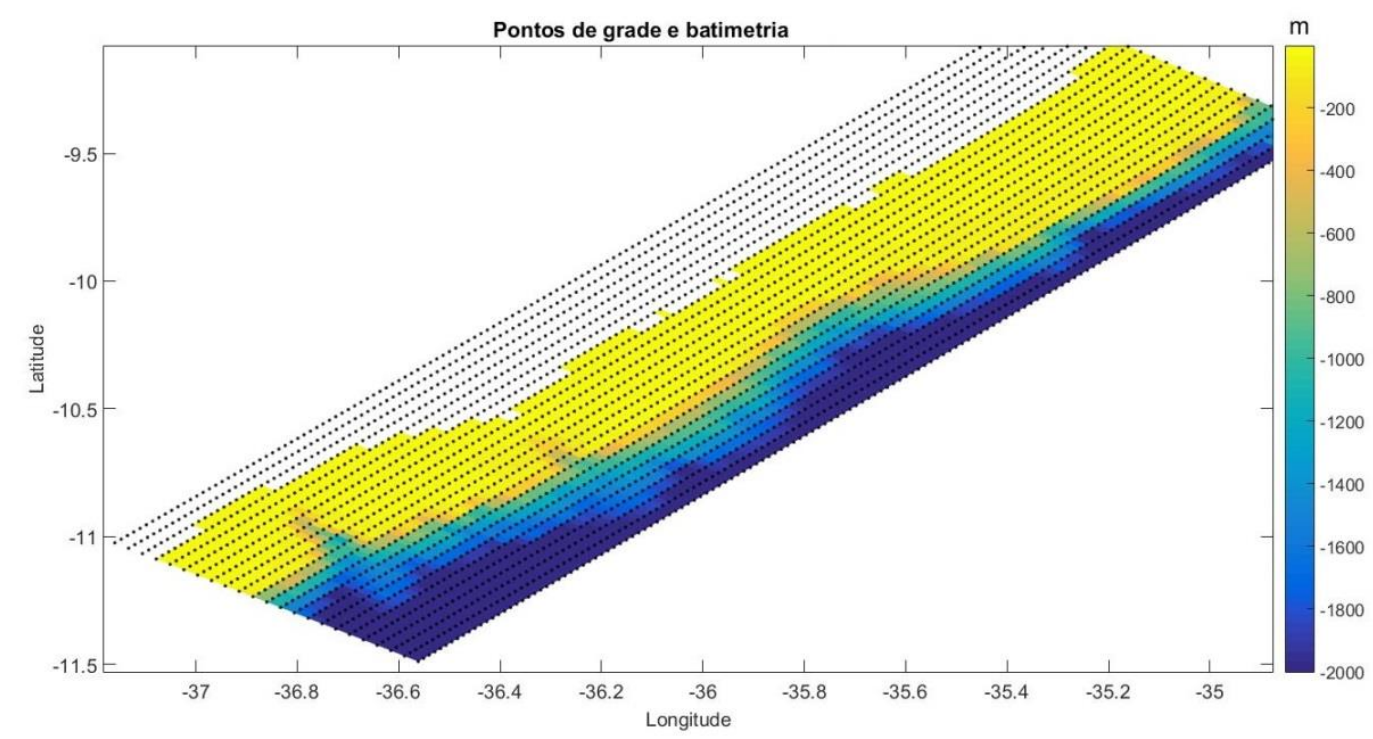

Figura 5 - Pontos de grade e batimetria utilizados no modelo 
O passo de tempo utilizado foi de 60 segundos, e um período de processamento de 30 dias para cada cenário. O pré-processamento foi feito utilizando 15 dias de aquecimento, sendo 5 desses dias de ramp (aumento gradual linear das forçantes para evitar instabilidade). Os dados de pré-processamento não foram analisados, e são suficientes para estabilizar o modelo, como será mostrado mais a frente.

O presente trabalho analisará situações em que dados de vento, aporte fluvial e campos de temperatura e salinidade foram adicionados ao modelo como forçantes, sendo que os campos de temperatura e salinidade são responsáveis por gerar a SNB. Nos contornos, foram adicionados dados de temperatura, salinidade, elevação do nível do mar e velocidade das correntes. Já no domínio foram adicionados dados de temperatura e salinidade. A validação das correntes obtidas pela ação de vento e aporte fluvial inseridos no modelo foi realizada por Parente (2016). Todos os dados utilizados de temperatura, salinidade, elevação do nível do mar e velocidade são provenientes do Mercator Ocean (Lellouche et al., 2016), enquanto que os dados de vento são provenientes do NCEP (NCEP/NCAR Global Reanalysis Products, 1994), com resolução temporal de 6 horas.

Para todas as simulações que o aporte fluvial é considerado, foi utilizado o modo prognóstico do modelo, em que os valores de temperatura e salinidade variam com o tempo dentro da grade, uma vez que é inserida água com salinidade 0 , diferente do seu entorno, permitindo avaliar a ação desta forçante. Já para as outras simulações em que não é considerado o aporte fluvial, foi utilizado o modo diagnóstico do modelo, em que os valores de temperatura e salinidade são mantidos constantes no tempo, uma vez que apresentaram resultados mais próximos das características médias que representam o fluxo da SNB.

\section{2 - Dados utilizados}

Com o objetivo de avaliar quais as condições de vento características da região, foi analisado inicialmente um conjunto de dados de ventos obtidos in situ na plataforma continental PCM-9 (Figura 6, 1059'12"S e 3656'53'W), dentro do Projeto de Caracterização Regional da bacia Sergipe-Alagoas (PCR-SEAL) 
financiado pela PETROBRÁS, entre 09 de março de 2012 e 31 de dezembro de 2014, representado na rosa-dos-ventos da Figura 7.

A batimetria da região foi obtida através de cartas náuticas digitalizadas fornecidas pela Diretoria de Hidrografia e Navegação (DHN) da Marinha do Brasil.

Os dados de aporte fluvial foram fornecidos pelo Instituto Nacional de Meteorologia (INMET, http://www.inmet.gov.br), e foram considerados três pontos de vazão: em frente ao rio São Francisco, ao rio Vaza Barris e ao rio Sergipe (Figura 6). Foi adicionada água com salinidade 0 e temperatura $27^{\circ} \mathrm{C}$ (temperatura média da plataforma continental) nesses pontos. As vazões estão apresentadas na Tabela 1, e foram consideradas constantes em todas as simulações. Foram utilizados dados de julho de 2014 pois foi o mês com maior aporte fluvial daquele ano.

Tabela 1 - Vazão fluvial considerada no modelo para os rios São Francisco, Vaza Barris e Sergipe. Dados do INMET para julho de 2014.

\begin{tabular}{|c|c|}
\hline & Vazão $\left(\mathrm{m}^{3} / \mathrm{s}\right)$ \\
\hline Rio São Francisco & 1217,2 \\
\hline Rio Vaza Barris & 16,2 \\
\hline Rio Sergipe & 2,8 \\
\hline
\end{tabular}

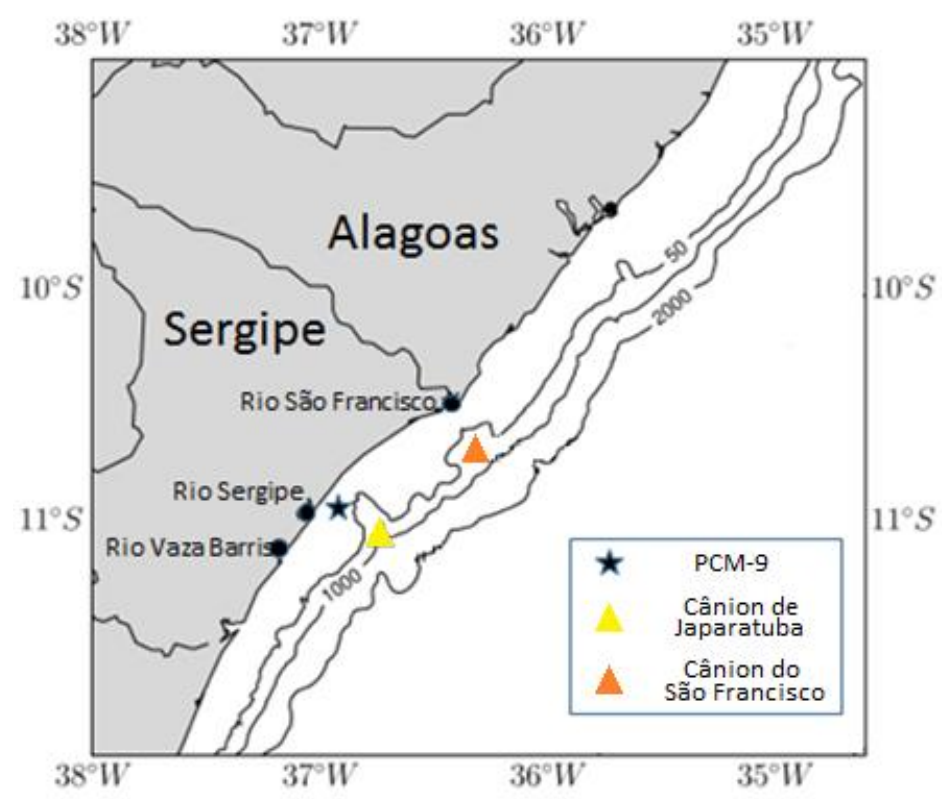

Figura 6 - Pontos de aporte fluvial, os rios São Francisco, Vaza Barris e Sergipe, e localização da plataforma PCM-9 e dos cânion de Japaratuba e do Sâo Francisco. Figura adaptada de Parente (2016). 
Os dados de temperatura, salinidade, elevação do nível do mar e correntes foram obtidos do modelo Mercator Ocean (Lellouche et al., 2016) para os meses de março, julho e setembro de 2014, tanto nos contornos quanto para as condições iniciais, sendo que nos contornos são mantidos constantes temporalmente (exceto nas simulações com aporte fluvial). Tais dados provenientes do Mercator são médias mensais referentes à cada mês simulado, e a resolução espacial é de 1/12 .

\section{3 - Tratamento dos dados e cenários utilizados no modelo}

Para descrever a circulação na região de estudo e nas proximidades dos cânions, e estimar os diferentes fluxos de volume nas seções dos cânions, foram realizadas simulações em diferentes condições de vento, temperatura, salinidade, e de aporte fluvial. O objetivo dessas simulações é avaliar a influência de cada forçante separadamente e em conjunto. Para simular a ação da SNB, foram adicionados dados de temperatura e salinidade característicos da região.

Inicialmente, foi avaliado o histórico de dados de vento da região, obtidos na plataforma PCM-9 (Figura 6), entre 09 de março de 2012 e 31 de dezembro de 2014 (representado na rosa-dos-ventos da Figura 7), para inferir quais direções preferenciais de vento ocorrem e utilizá-las nas simulações. Foi observado que as condições preferenciais de vento no período foram para ventos de Nordeste, de Leste, de Sudeste e de Sul. Desta forma, foram realizadas simulações sem vento, e com ventos de Nordeste, Leste, Sudeste e Sul, com intensidade de $6,5 \mathrm{~m} . \mathrm{s}^{-1}$ (valor médio no período), constantes no tempo e espaço, com o campo de temperatura e salinidade referente aos meses de março, julho e setembro de 2014. 


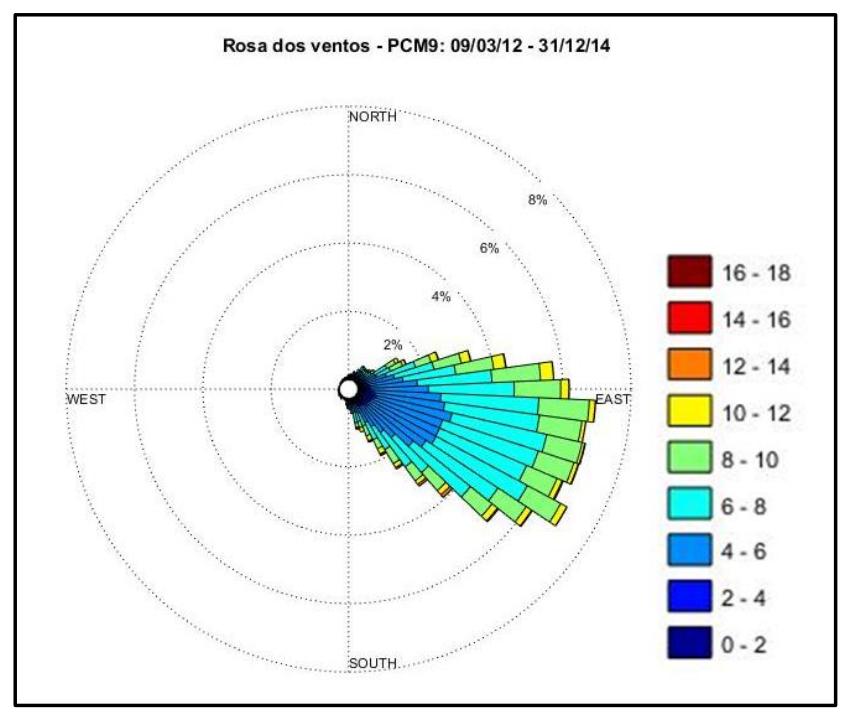

Figura 7-Rosa-dos-ventos da série temporal de 09/03/12 até 31/12/14, na plataforma de petróleo PCM-9. Dados fornecidos pela Petrobrás.

Posteriormente, foi inserido o aporte fluvial, sem considerar a ação do vento, para o campo de temperatura e salinidade nos meses de março, julho e setembro de 2014, para avaliar sua influência em diferentes condições.

Para finalizar, foram realizadas simulações com dados de vento variáveis do NCEP (NCEP/NCAR Global Reanalysis Products, 1994), para os meses de Março, Julho e Setembro de 2014, com o campo de temperatura e salinidade referente a esses meses. Foi realizada interpolação espacial para cobrir a região de estudo ao longo do período simulado.

Desta forma, foram realizadas simulações nas condições de vento, temperatura, salinidade e aporte fluvial representadas na Tabela 2. Os pontos de introdução de aporte fluvial estão representados na Figura 6 e as vazões, na Tabela 1, e são considerados constantes no tempo.

A fim de facilitar a identificação de cada simulação, está apresentada na Tabela 2 um código de identificação (ID) utilizando uma letra para cada tipo de simulação, sendo A indicando condição sem vento e sem aporte fluvial, no modo diagnóstico, B identifica as simulações com ventos constantes nas direções de NE, E, SE e S; C e D são as simulações em modo prognóstico e sem vento, na ausência e na presença de aporte fluvial, respectivamente. E por fim, E indica as simulações com vento variando com o tempo, sem aporte fluvial. Todas elas utilizando temperatura e salinidade nos meses de março, julho e setembro, simulando a dinâmica da SNB. 
Tabela 2 - Condições de vento, aporte fluvial e campo de T e S utilizadas em cada simulação. Modo diagnóstico indica $T$ e $S$ constantes no tempo, enquanto o modo prognóstico permite variação de $T$ e $S$.

\begin{tabular}{|c|c|c|c|c|}
\hline Direção do vento & Aporte fluvial & Campo TS & Modo & ID \\
\hline Vento ausente & Ausente & Março, julho e setembro & Diagnóstico & A \\
\hline $45^{\circ}$ (Nordeste) & Ause & Março, julho & tico & \\
\hline $90^{\circ}$ (Leste) & e & Março, julho e setembro & Diag & \\
\hline $135^{\circ}$ (Sudeste) & Ausente & Março, julho e setembro & Diagnóstico & \\
\hline $180^{\circ}$ (Sul) & Ausente & Março, julho e setembro & Diagnóstico & \\
\hline Vento ausente & Presente & Março, julho e setembro & Prognóstico & $\mathrm{C}$ \\
\hline Vento ausente & Ausente & Março, julho e setembro & Prognóstico & $\bar{D}$ \\
\hline (NCEP) & Ausente & Março, julho e setembro & Diagnóstico & $\mathrm{E}$ \\
\hline
\end{tabular}

Para cada um dos cenários da Tabela 2, será descrita a circulação na área de estudo e próximo aos cânions de Japaratuba e do São Francisco, além de se calcular o fluxo de volume nas seções verticais dos cânions (Figura 8), paralelas à costa, afim de compará-los. Para os 3 cenários $E$, os dados de vento e de fluxo de volume serão relacionados.

Serão comparados os cenários A (sem vento) e B (com vento), para avaliar a influência de cada direção do vento na circulação e no transporte, uma vez que o campo de temperatura e salinidade são mantidos constantes. Também serão comparados o cenários $C$ (sem vento e com aporte fluvial) e $D$ (sem vento e sem aporte fluvial), para avaliar a influência da ação do aporte fluvial, uma vez que não haverá influência do vento. A diferença entre os cenários A e D é que o primeiro é realizado com $T$ e $S$ constantes dentro da grade do modelo, enquanto que 0 segundo é realizado com $T$ e $S$ variando. Em ambos os casos, $T$ e $S$ são constantes no contorno. Por fim, serão comparados o transporte nas seções dos cânions com a ação do vento em diferentes meses para os cenários $\mathrm{E}$, uma vez que os campo de $T$ e $S$ são mantidos constantes.

A Figura 8 apresenta 5 cortes onde foram feitas seções verticais para permitir a análise dos resultados. Os dois primeiros cortes são paralelos à costa e representam as seções dos cânions de Japaratuba e do São Francisco onde foram feitos os cálculos do fluxo de volume de água trocada entre o cânion e o oceano profundo. Os outros três cortes são perpendiculares à costa, um ao Sul do cânion de 
Japaratuba (Seção Sul), outro entre os dois cânions (Seção Central), e outro a Norte do cânion do São Francisco (seção Norte), e foram feitos para descrever melhor a circulação em torno dos cânions.

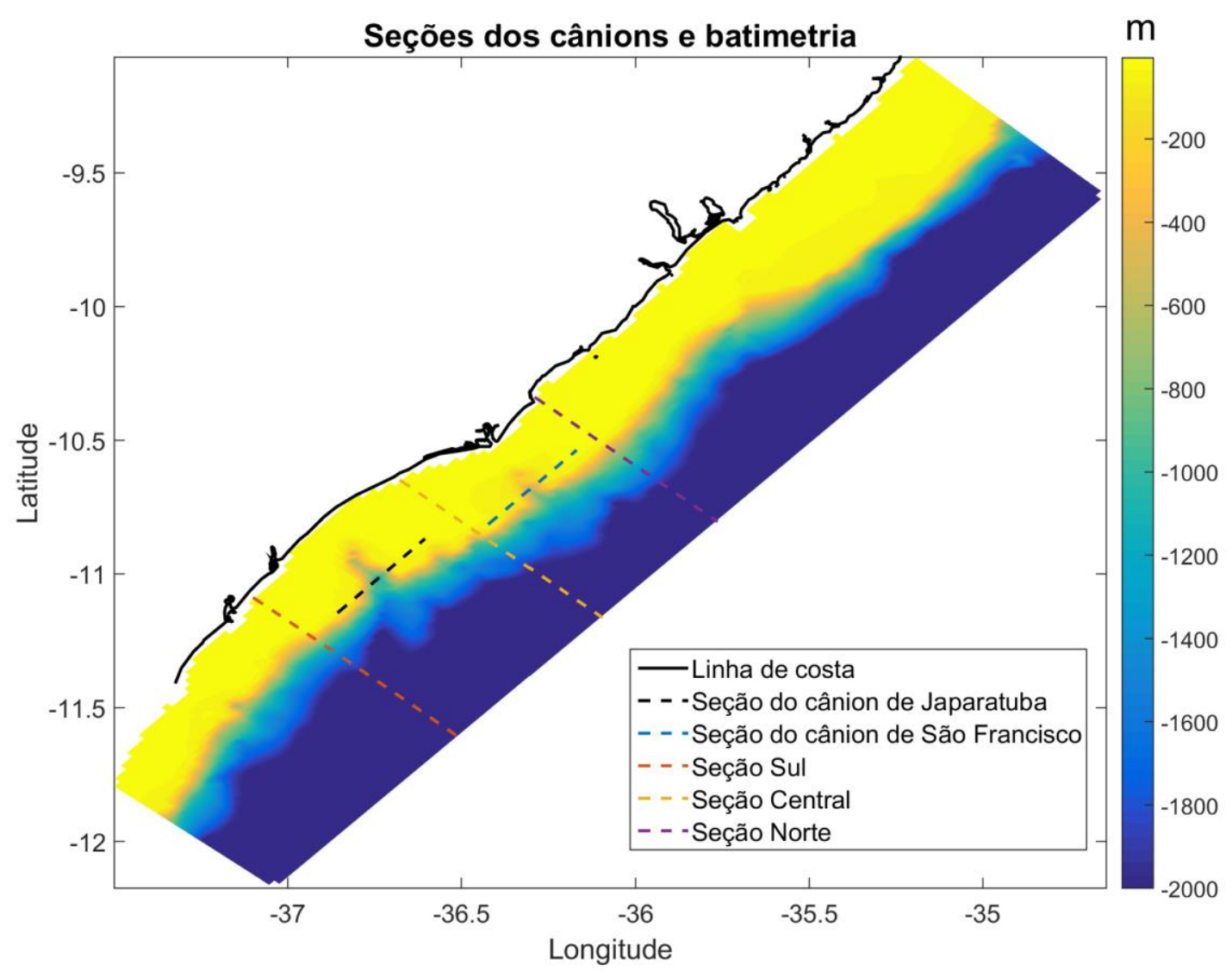

Figura 8 - Cortes de seções verticais próximas aos cânions de Japaratuba e São Francisco: duas paralelas à costa, e três perpendiculares a costa, uma a Sul do cânion de Japaratuba, uma entre os cânions e a uma a Norte do cânion do São Francisco.

O cálculo do fluxo de volume $(Q)$ na seção paralela à costa, cortando os cânions verticalmente (cortes ilustrados na Figura 8), foi realizado através da integral da velocidade perpendicular $\left(v_{\perp}\right)$ à seção pela área (Equação 7$)$.

$$
Q=\iint v_{\perp} \cdot d A
$$

Para diminuir a influência das correntes na plataforma continental no fluxo de volume, serão considerados no cálculo profundidades maiores que $50 \mathrm{~m}$. Valores 
negativos de velocidade perpendicular e de fluxo de volume significam movimentos de águas de regiões mais profundas em direção ao cânion, enquanto valores positivos indicam fluxo do cânion em direção ao oceano aberto.

Para todas as simulações sem vento e com ventos constantes para os meses de março, julho e setembro, foi utilizado o modo diagnóstico do modelo, ou seja, os valores de temperatura e salidade são mantidos constantes com o tempo, e simulam a ação do fluxo médio mensal da SNB. Serão comparados os cenários tipo A (sem vento) com os cenários $B$ (com vento), para avaliar a influência da ação dos ventos em cada direção. Toda a análise é feita para o tempo final da simulação, ou seja, após 45 dias ( 15 de aquecimento além dos 30 dias de simulação). Em todas as simulações, os campos de $T$ e $S$ são médias referentes à cada mês simulado, com os resultados apresentados no tempo final de simulação. 


\section{3 - Resultados}

\section{1 - Forçantes: Campo de $T$ e $S$ (SNB) e vento (sem aporte fluvial)}

A Figura 9 apresenta o diagrama TS para os 3 meses simulados, e as respectivas massas d'água presentes. Podemos observar que os meses de julho e setembro apresentam campos de TS praticamente idênticos. O mês de março apresenta águas mais quentes e menos salinas na região da Água Tropical (AT) que nos outros meses, águas mais frias e mais salinas para a região da Água Central do Atlântico Sul (ACAS) que nos outros meses, e mais salina na região da Água Intermediária Antártica (AIA). Em março, a temperatura varia de 3,3 a $29,5^{\circ} \mathrm{C}$, e a salinidade varia de 34,4 a 37,3 . Os meses de julho e setembro apresentam temperaturas entre 3,2 e $26,6^{\circ} \mathrm{C}$, e salinidade entre 34,3 e 37,5 .

Comparando os diagramas TS utilizados em nosso modelo com o diagrama obtido por Silveira et. al (1994) nos cruzeiros realizados entre maio e julho de 1986 (Figura 10), para a mesma região de estudo, em ambos são observadas as presenças das massas d'água AT, ACAS e AIA. As temperaturas obtidas nos cruzeiros variam de 4 a $28^{\circ} \mathrm{C}$, e a salinidade varia de 34,2 a 37,2 .
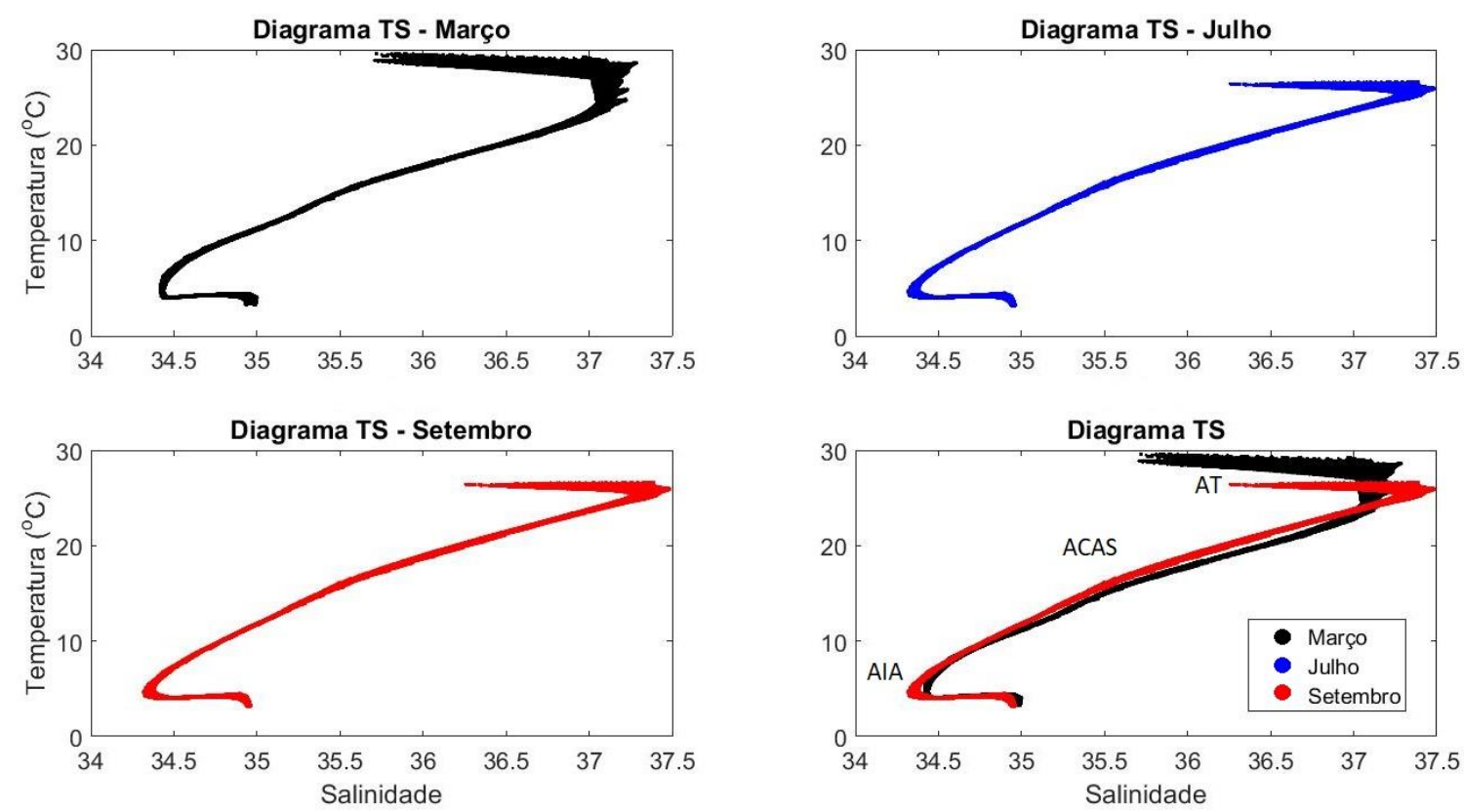

Figura 9 - Diagrama TS para os meses de março, julho e setembro, e respectivas massas d'água 


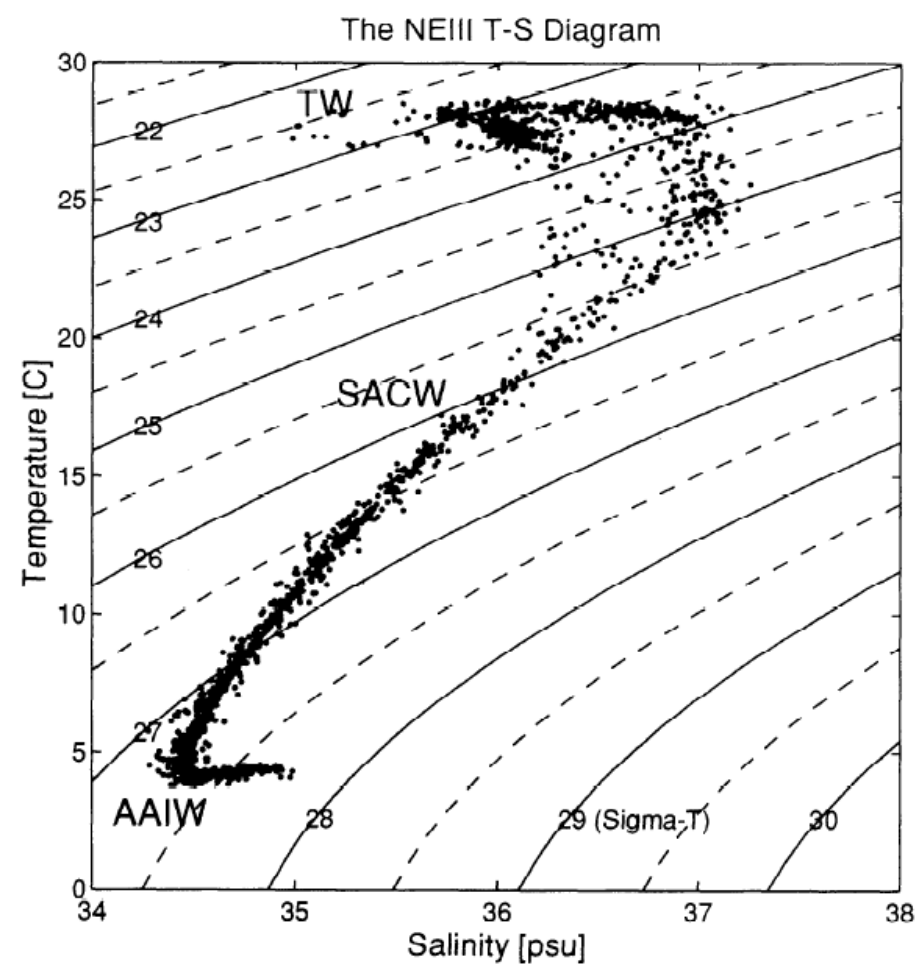

Figura 10 - Diagrama TS do cruzeiro NEIII. Indica a presença de Água Tropical (TW), Água Central do Atlântico Sul (SACW) e Água Intermediária Antártica (AAIW). Retirado de Silveira et. al (1994)

\subsection{1 - Cenários sem vento (A)}

As correntes a 100, 200, 300 e $400 \mathrm{~m}$ de profundidade, para o tempo final de simulação são apresentadas nas Figuras 11, 12 e 13, para os meses de março, julho e setembro, respectivamente. $\mathrm{O}$ mês de setembro apresenta as correntes mais intensas entre os 3 meses, o que pode ser observado na Figura 13 em 4 profundidades diferentes, e na Figura 14, nas 3 seções perpendiculares à costa. Ele é seguido pelo mês de março (Figura 11), e julho é o mês com as correntes menos intensas (Figura 12). Nas 3 seções perpendiculares à costa (Figura 14) é possível verificar que o mês de julho apresenta as correntes menos intensas na seção Norte, enquanto que nas outras duas seções é o mês de março que apresenta as correntes menos intensas.

$\mathrm{Na}$ (Figura 14) podemos observar que o núcleo da SNB ocorre em diferentes profundidades dependendo da seção e do mês simulado. Em março, nas seções Sul e Central, o núcleo fica em torno de $300 \mathrm{~m}$ de profundidade, enquanto que na seção Norte está entre 150 e 200 m. No mês de julho, o núcleo está em torno de 200 m de 
profundidade em todas as seções. Em setembro, o núcleo está a $500 \mathrm{~m}$ na seção Sul, e entre 100 e $300 \mathrm{~m}$ nas outras duas seções. Também podemos observar um fluxo negativo próximo à região da plataforma continental $(\mathrm{PC})$, que varia de profundidade máxima de atuação, confirmados pelos gráficos de circulação a $100 \mathrm{~m}$ nas Figuras 11, 12 e 13.

Em março, a profundidade de correntes negativas chega a $300 \mathrm{~m}$ na seção Norte, passa de $600 \mathrm{~m}$ na seção Central, e fica restrita à PC na seção Sul. No mês de julho, velocidades negativas chegam a $600 \mathrm{~m}$ na seção Norte, passa de $600 \mathrm{~m}$ na seção Central, e fica restrita à PC na seção Sul. Já para o mês de setembro, as correntes negativas ficam restritas à PC nas seções Sul e Norte, e chegam a $500 \mathrm{~m}$ de profundidade na seção Central. Como esse fluxo negativo se dá no sentido indo para Sudeste, ele flui com a costa à sua direita, ou seja, fluxos "along-slope" negativo segundo a convenção de Allen e Madron (2009). Já a SNB vai para Nordeste, ou seja, flui com a costa à sua esquerda e, portanto, fluxo "along-slope" positivo. Nos 3 meses simulados, a profundidade que as correntes negativas atingem aumentam da seção Norte para a seção Central (limites do cânion do São Francisco), e diminui da seção Central para a seção Sul (limites do cânion de Japaratuba). Assim, ao passar pelo cânion do São Francisco, a corrente próxima à PC, indo para Sudeste, aumenta a profundidade, enquanto que ao passar pelo cânion de Japaratuba ela está diminuindo a profundidade.

A área apresentando correntes positivas na seção do cânion de Japaratuba em março é maior que nos outros meses (Figura 15). Pela Figura 17 é possível verificar que entre 100 e $350 \mathrm{~m}$ de profundidade, o mês de março apresenta transporte maior que os outros meses no cânion de Japaratuba. $O$ mês de julho apresenta transporte negativo entre 100 e $250 \mathrm{~m}$, sendo o mês com menor transporte total. Já para o cânion do São Francisco, verificamos pela Figura 17 que o mês de março apresenta o transporte mais negativo entre 50 e $400 \mathrm{~m}$ de profundidade, o que pode ser observado na Figura 16, onde é notável que o transporte é mais negativo entre a superfície e $50 \mathrm{~m}$ de profundidade para os meses de julho e setembro, e entre 50 e $300 \mathrm{~m}$ de profundidade para o mês de março. Ao integrar verticalmente o transporte nos cânions de Japaratuba e do São Francisco, são obtidos valores positivos para o primeiro, e negativos para o segundo, em todos os meses simulados, ou seja, o fluxo no cânion de Japaratuba é predominantemente 
indo do cânion em direção a regiões mais profundas, enquanto que no cânion do São Francisco o predomínio é de fluxo indo de regiões mais profundas em direção ao cânion (Figura 18).
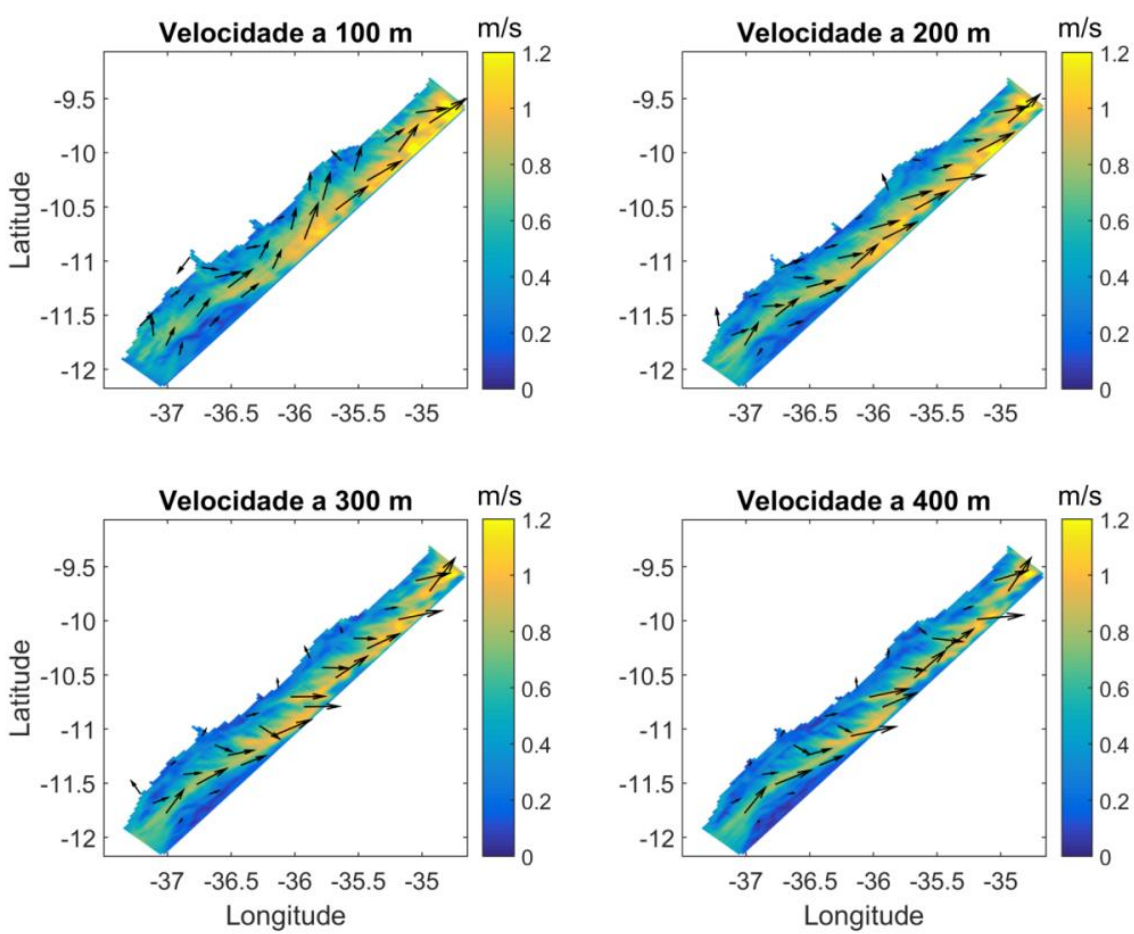

Figura 11 - Circulação na área de estudo para março, sem vento, a 100, 200, 300 e 400 m.
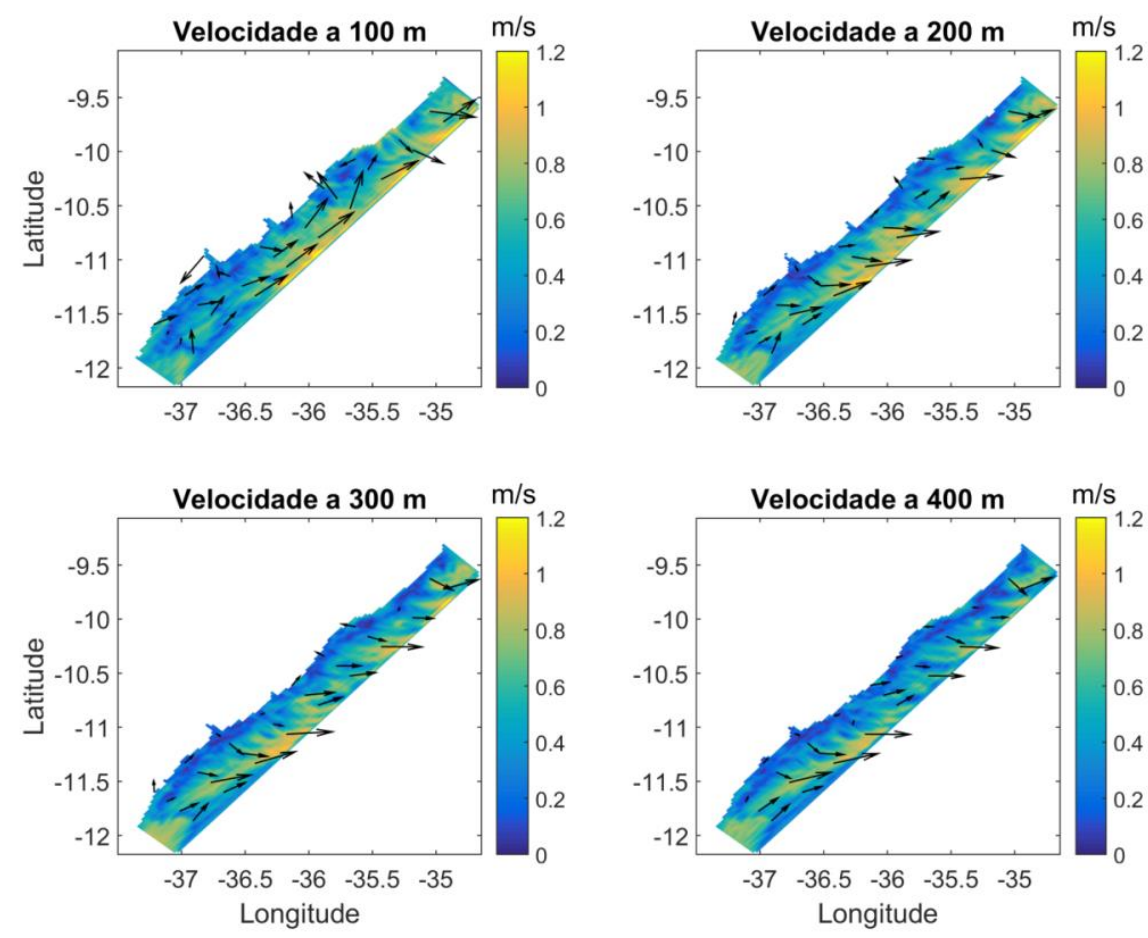

Figura 12 - Circulação na área de estudo para julho, sem vento, a 100, 200, 300 e 400 m. 

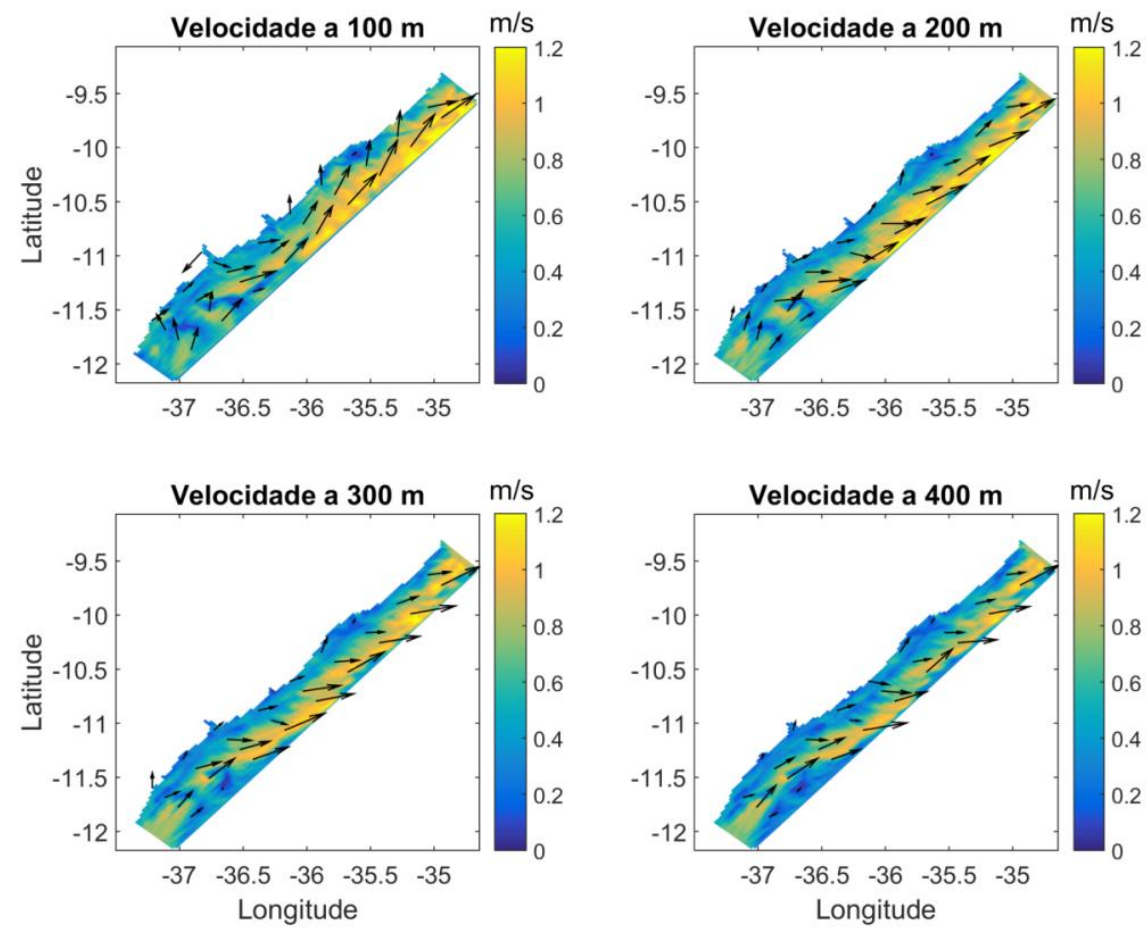

Figura 13 - Circulação na área de estudo para setembro, sem vento, nas profundidades 100, 200, 300 e $400 \mathrm{~m}$. 


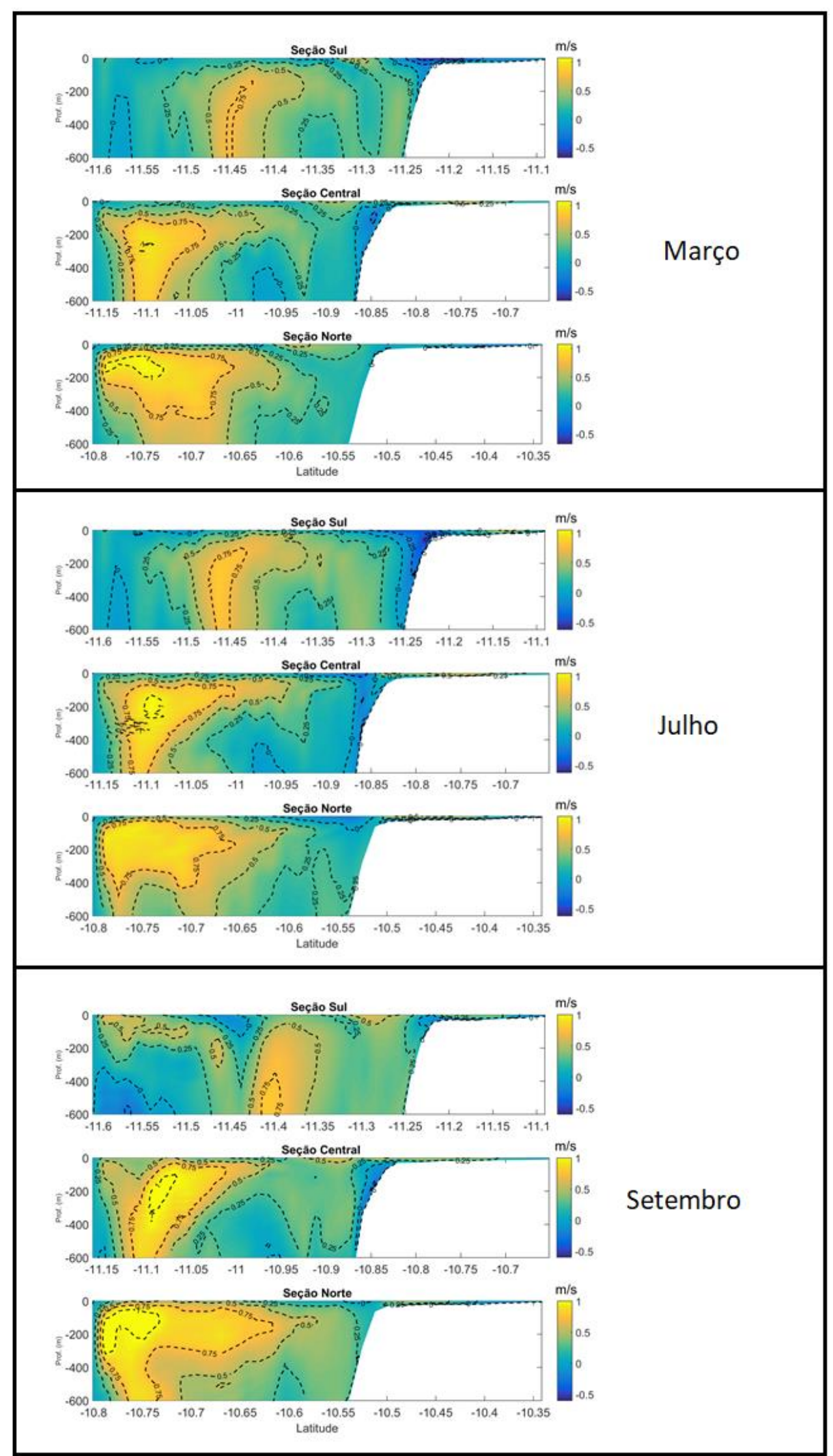

Figura 14 - Correntes nos meses de março, julho e setembro, sem vento, nas seções Sul, Central e Norte. 

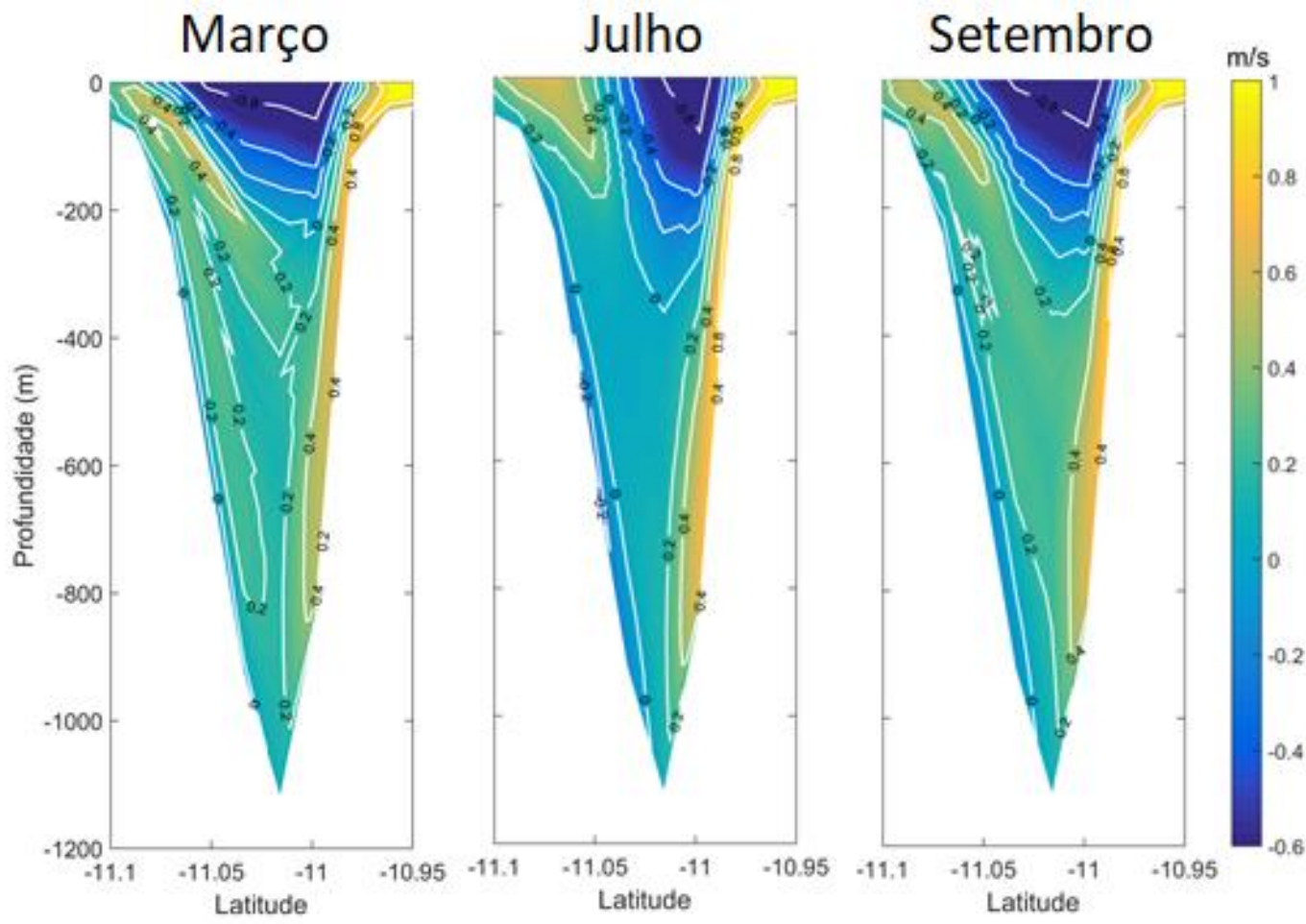

Figura 15 - Correntes nas seções do cânion de Japaratuba em março, julho e setembro, sem vento
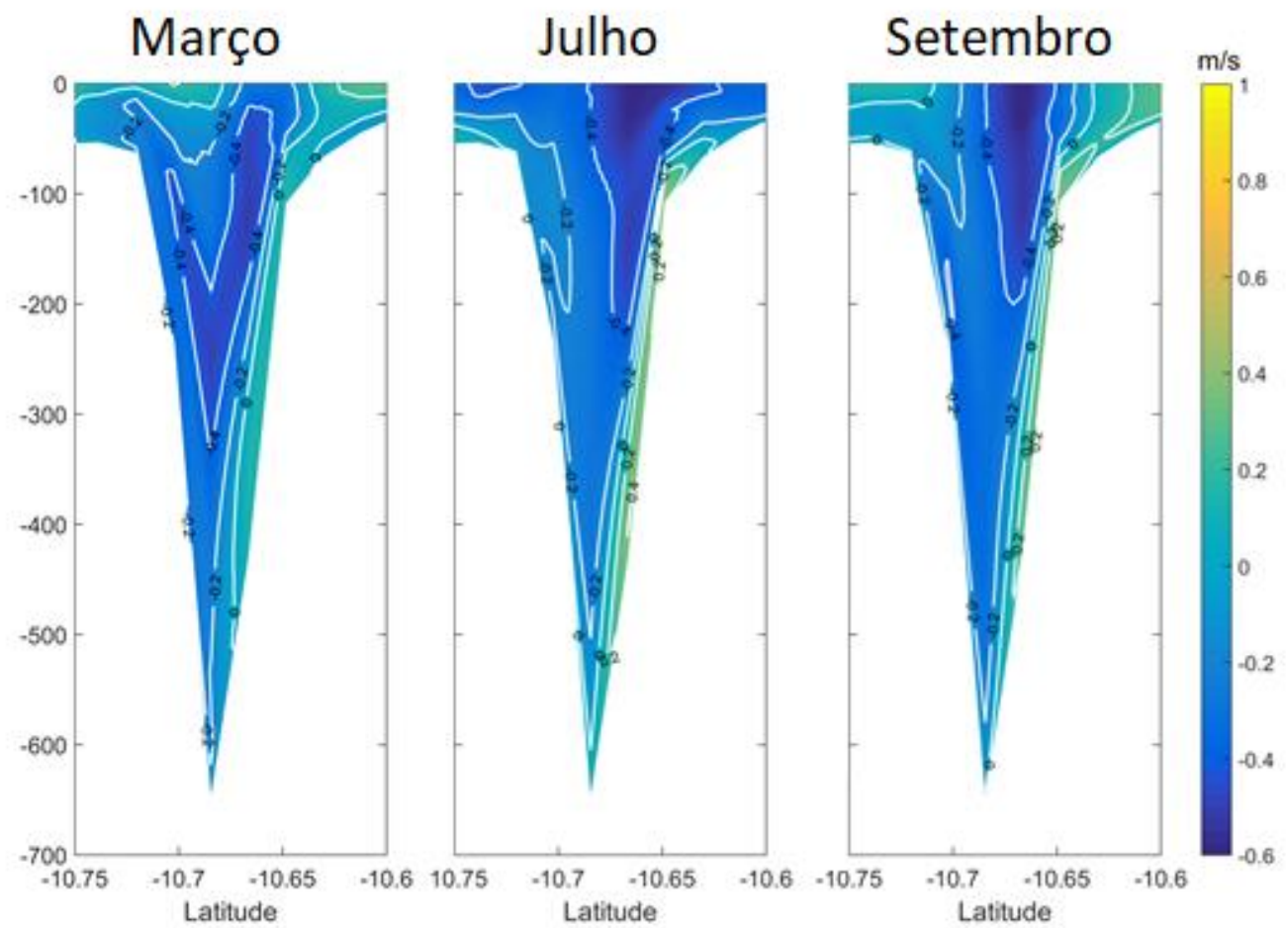

Figura 16 - Correntes nas seções do cânion do São Francisco em março, julho e setembro, sem vento 

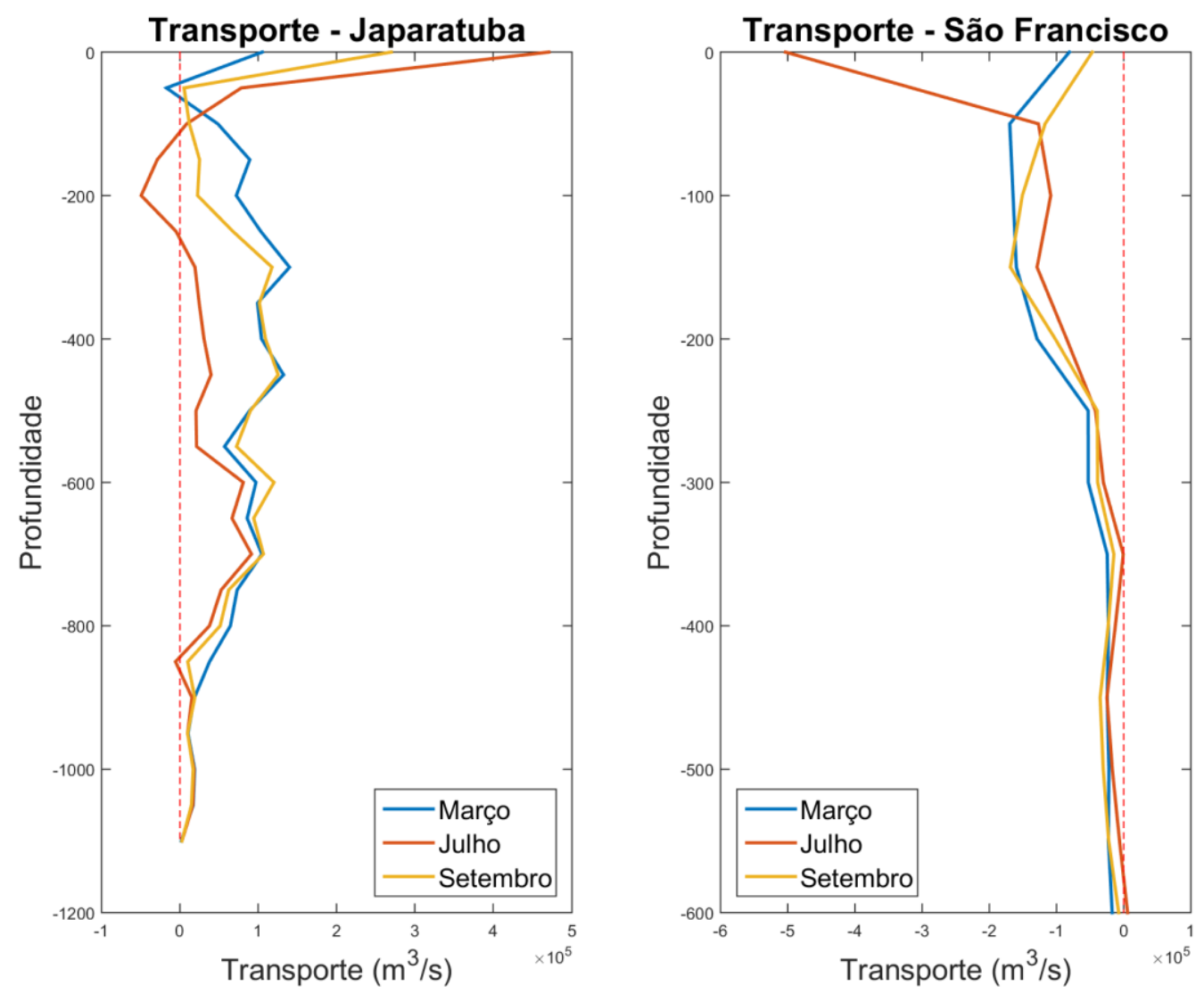

Figura 17 - Transporte em função da profundidade nas seções dos cânions de Japaratuba e do São Francisco para os meses de março, julho e setembro, sem vento

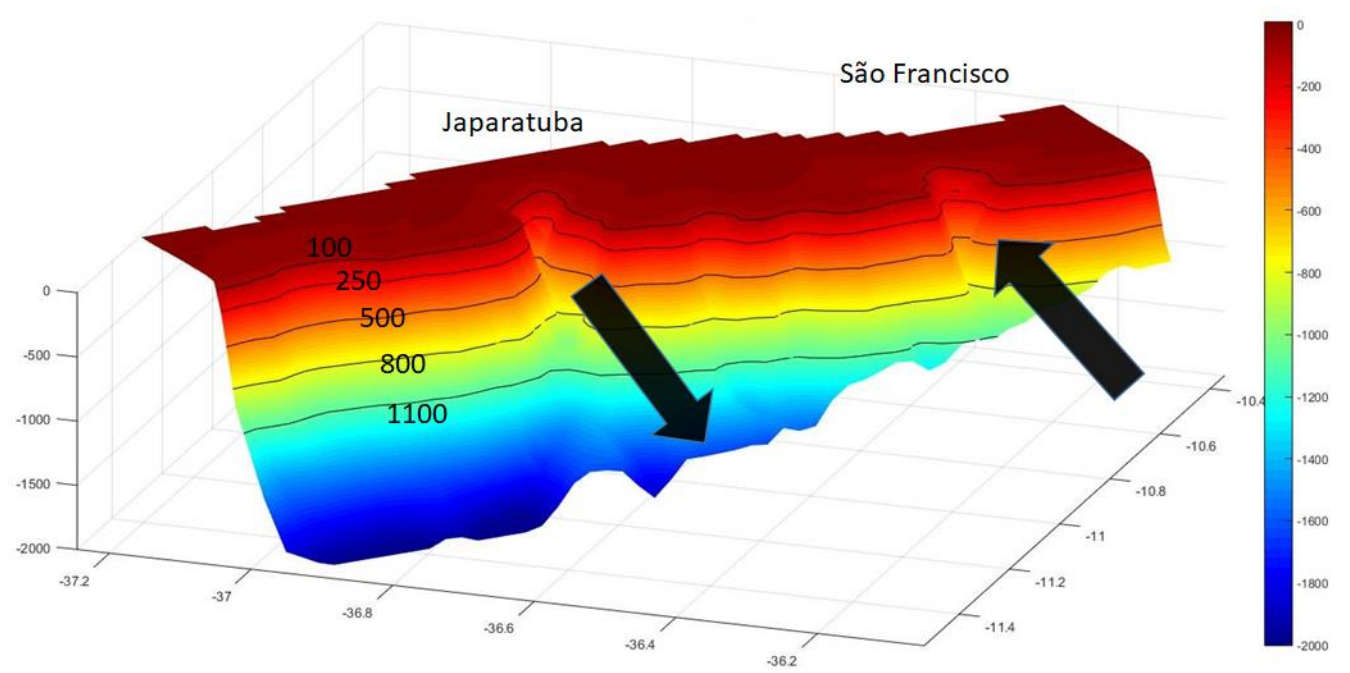

Figura 18 - Batimetria da região em torno dos cânions, e direção dos fluxos predominantes, sendo positivos para o cânion de Japaratuba (esq.) e negativos para o cânion do São Francisco (dir.) 


\subsection{2 - Março: Cenários com ventos de Nordeste, Leste, Sudeste e Sul (B)}

Os campos de temperatura e salinidade nos cânions de Japaratuba e do São Francisco que foram utilizados no mês de março estão apresentados na Figura 19, nas seções mostradas na Figura 8. No cânion de Japaratuba (Figura 19 esq.), a salinidade varia de 34,5 até 37 , sendo mais salino em regiões mais rasas, enquanto a temperatura cai de $2^{\circ} \mathrm{C}$ a $100 \mathrm{~m}$ de profundidade até $5^{\circ} \mathrm{C}$ no fundo. Já no cânion de Sâo Francisco (Figura 19 dir.), a salinidade vai de 35 até 37, também mais salino em regiões mais rasas, com temperaturas variando de $8^{\circ} \mathrm{C}$ a $25^{\circ} \mathrm{C}$.

A circulação na área de estudo para as profundidades 100, 200, 300 e 400 m, nas condições de ventos constantes (simulações B) para ventos de Nordeste (Figura 20), Leste (Figura 21), Sudeste (Figura 22) e Sul (Figura 23) apresentam-se bastante semelhantes, com predomínio do fluxo para Nordeste e Leste, com valores máximos chegando a $1,2 \mathrm{~m} . \mathrm{s}^{-1}$. As correntes mais intensas foram obtidas para a condição de ventos de Sul e Sudeste, enquanto as menos intensas foram obtidas para ventos de Nordeste. Os fluxos mais intensos ocorrem afastados da costa.
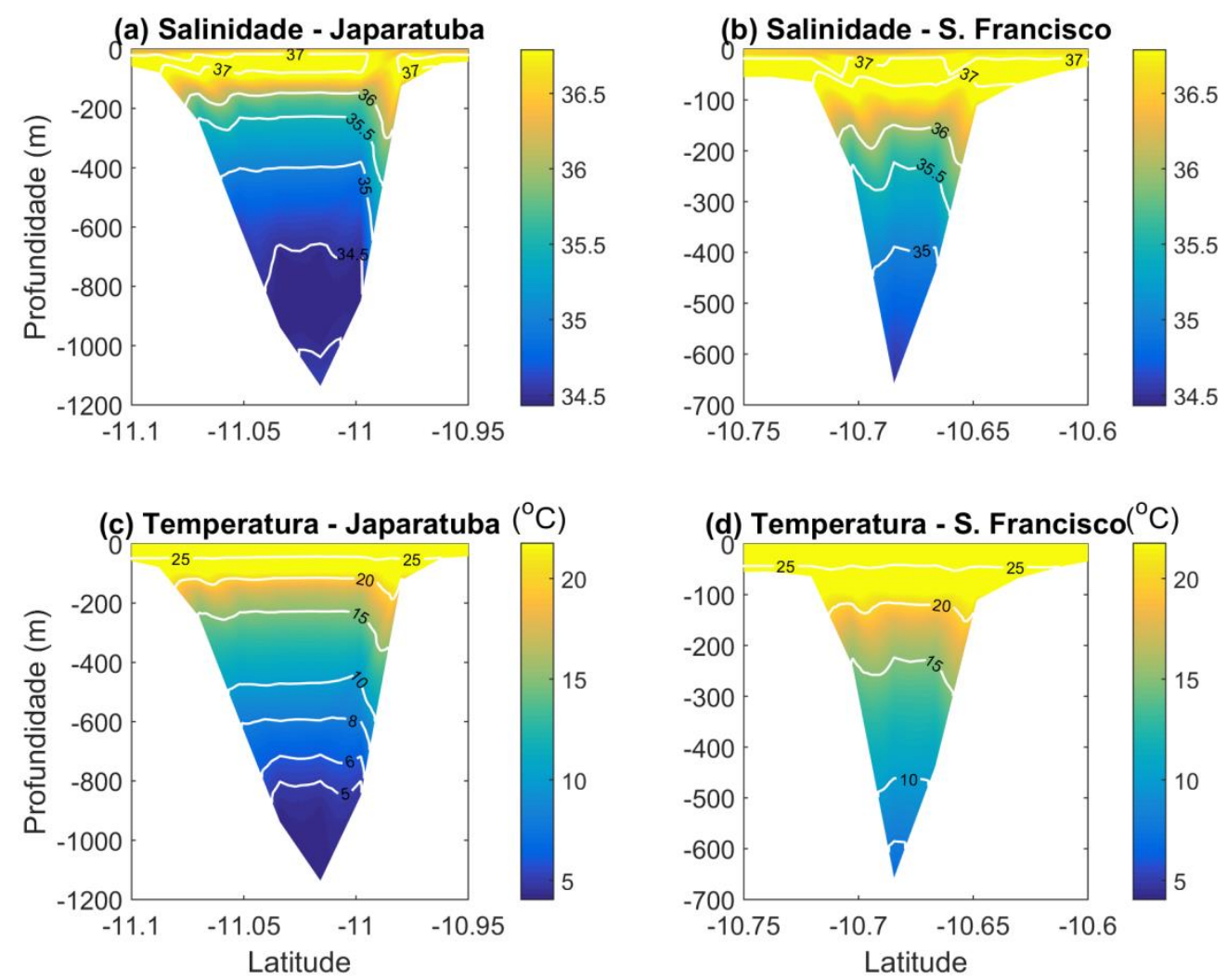

Figura 19 - Salinidade e temperatura nas seções dos cânions de Japaratuba e do São Francisco em março. 

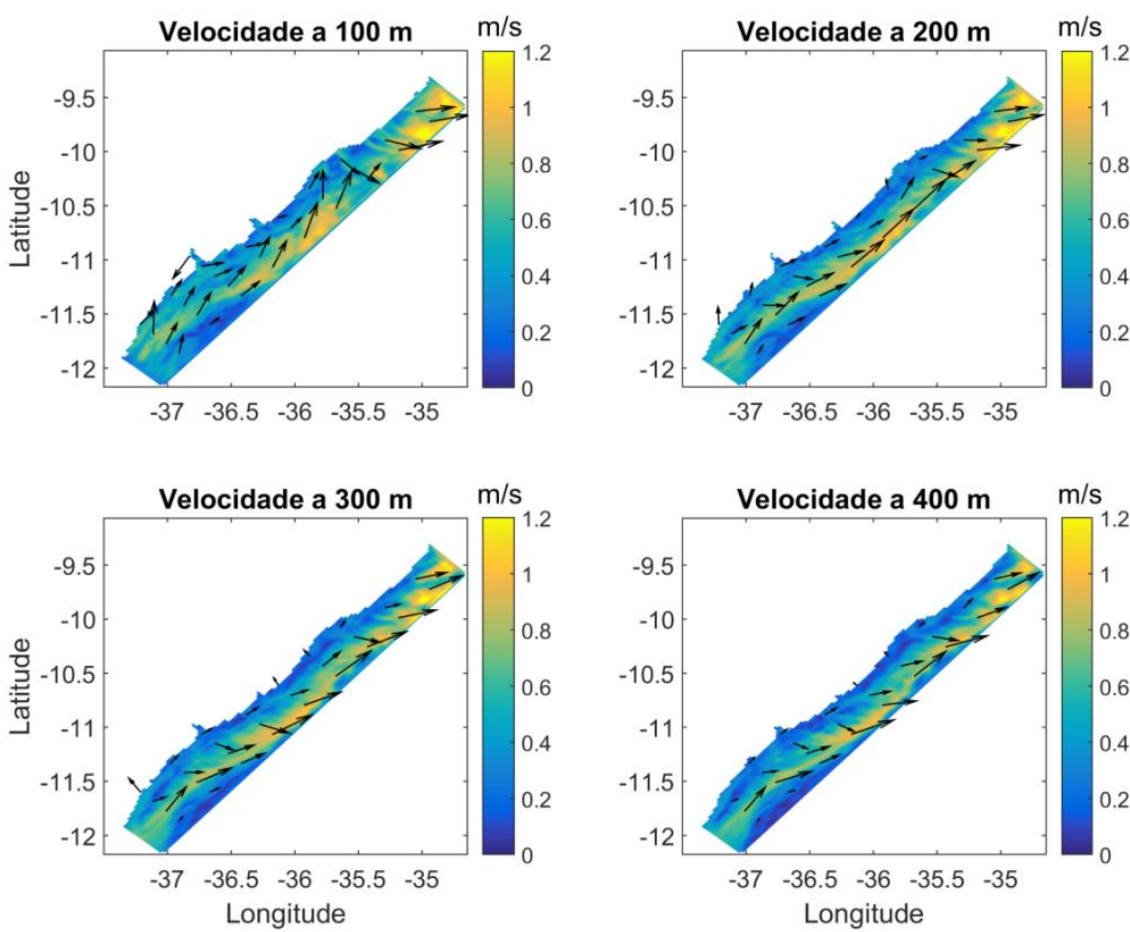

Figura 20 - Circulação na área de estudo para março e vento de Nordeste, a 100, 200, 300 e 400 m.
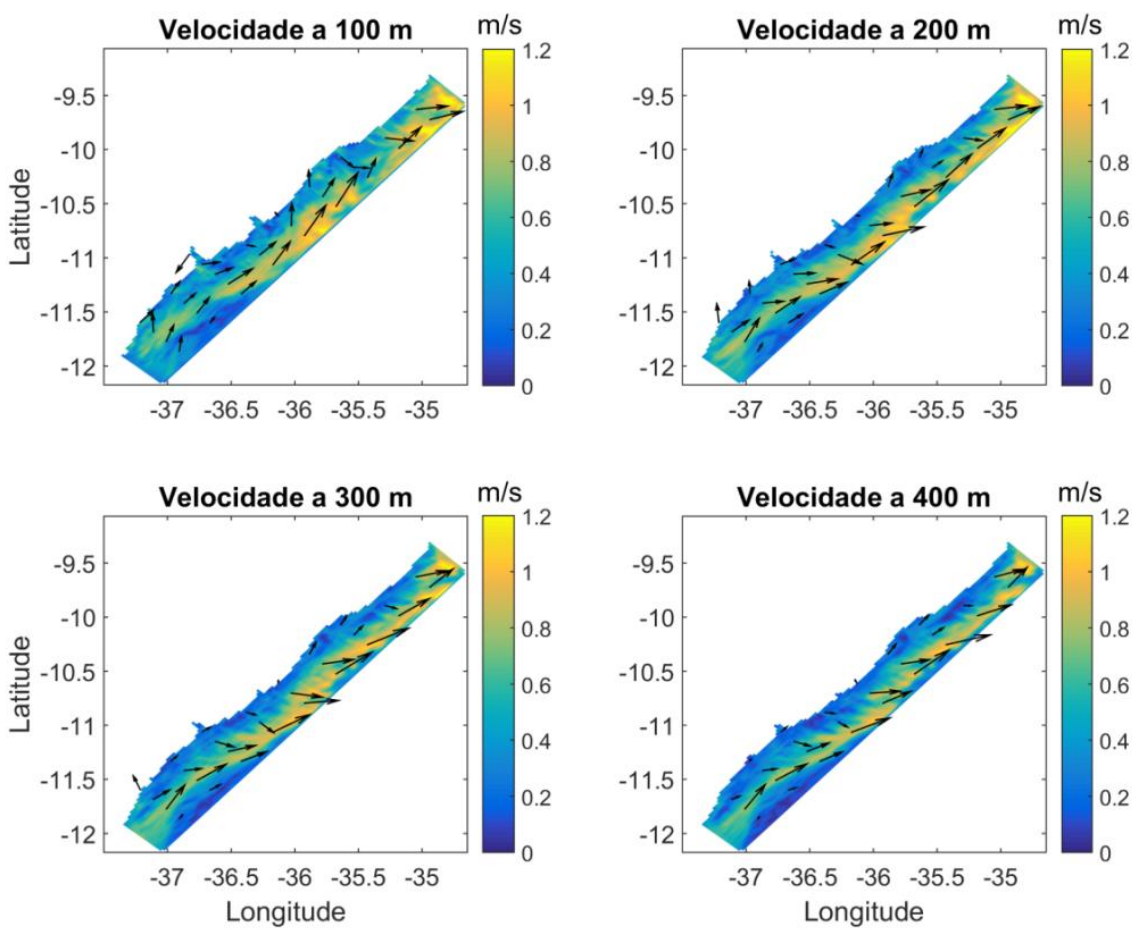

Figura 21 - Circulação na área de estudo para março e ventos de Leste, a 100, 200, 300 e 400 m. 

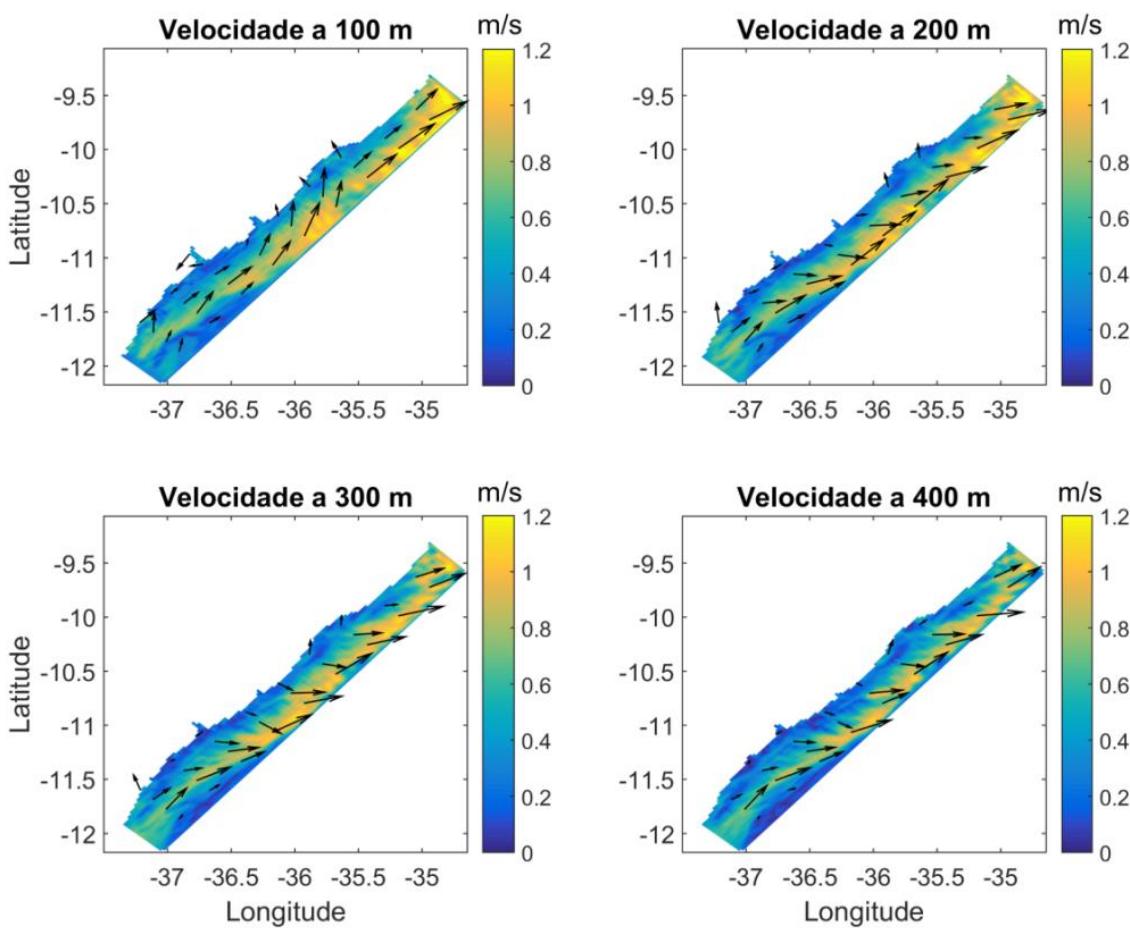

Figura 22 - Circulação na área de estudo para março e ventos de Sudeste, a 100, 200, 300 e 400 m.
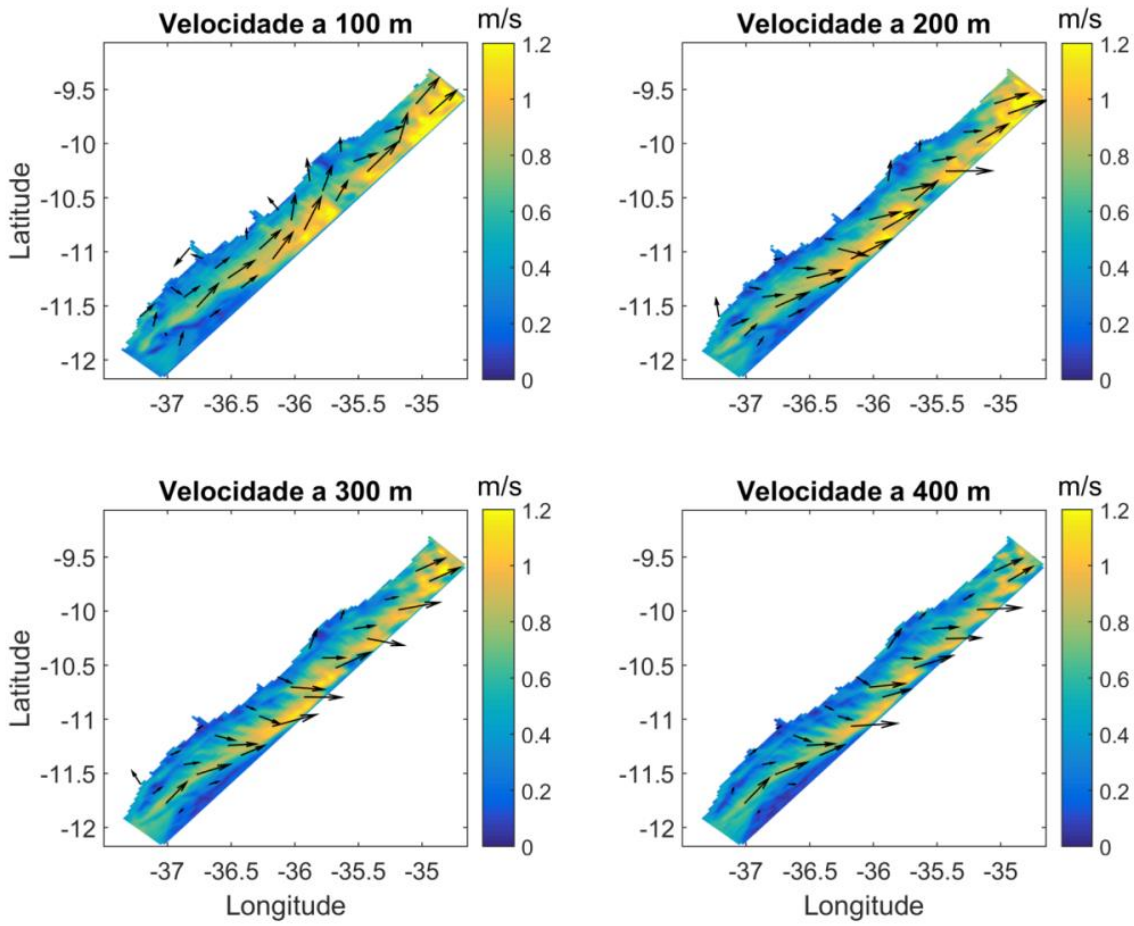

Figura 23 - Circulação na área de estudo para março e vento de Sul, a 100, 200, 300 e 400 m. 
Na Figura 24 são apresentadas a energia cinética por kg total, em função do tempo, para o mês de março, nas condições sem vento $(A)$, e de ventos de Nordeste, Leste, Sudeste e Sul (B). A energia cinética específica foi calculada somando o dobro do quadrado da velocidade de todos os pontos da grade utilizada no modelo. Os comportamento são semelhantes em todos os cenários, com aumento rápido até aproximadamente 12 dias, e posteriormente mantem seus valores abaixo de um patamar de 2,8 a $3 \times 10^{4} \mathrm{~J} / \mathrm{kg}$.

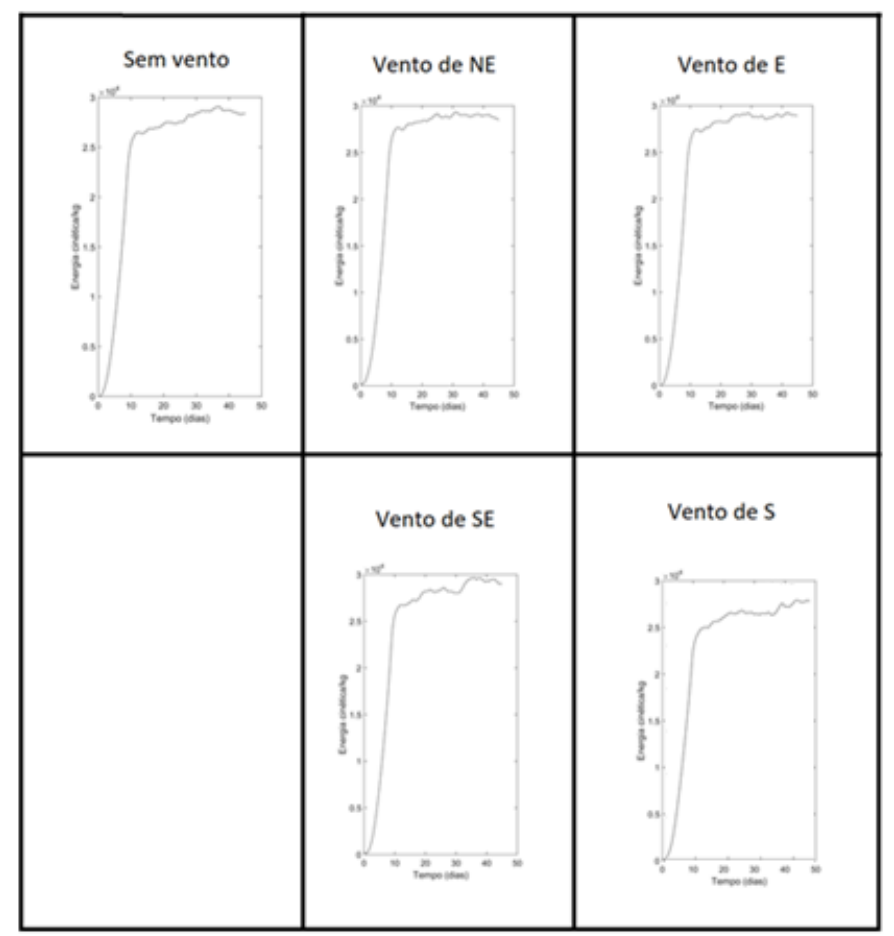

Figura 24 - Energia cinética em função do tempo para o mês de março, nas condições sem vento, e com ventos de NE, E, SE es.

As velocidades nas seções perpendiculares à costa (Figura 8) para as condições sem vento (Figura 14, painel superior), ventos de Nordeste (Figura 25), de Leste (Figura 26), de Sudeste (Figura 27) e de Sul (Figura 28), para o mês de março, apresentam algumas semelhanças. Observa-se um predomínio de correntes positivas, ou seja, para Nordeste. Há fluxos negativos na região de plataforma continental, indicando correntes para Sudoeste, podendo atingir profundidades de até $600 \mathrm{~m}$. Também pode ser observado que o núcleo da corrente ocorre em subsuperfície, localizado entre 100 e $400 \mathrm{~m}$, com valores máximos variando entre 0,8 e 1,2 m.s. . $^{-1}$. 
Ao adicionarmos a ação dos ventos (B) e compararmos com a condição sem vento $(A)$, são observadas algumas alterações.

Ao adicionar vento de Nordeste, podemos observar uma intensificação das correntes em todas as seções, com o núcleo na seção Norte em formato mais circular e alguns metros mais profundo, por volta de $200 \mathrm{~m}$. Também há um aumento na região de fluxos negativos próximo à costa na seção Norte, que estava restrito à PC na condição sem vento, e passou a atingir mais de $600 \mathrm{~m}$ de profundidade, ou seja, na região do cânion do São Francisco (entre as seções Central e Norte), houve aumento da profundidade de ação das correntes indo para Sul. Quando se adicionou vento de Leste, também houve intensificação das correntes em todas as seções. Porém, o núcleo na seção Norte não afundou tanto quanto para a condição de vento de Nordeste, ficando em aproximadamente $150 \mathrm{~m}$.

Quando foi adicionado vento de Sudeste, houve uma intensificação na região próxima ao núcleo da SNB na seção Sul, porém, houve atenuação na região mais próxima à costa. Situação semelhante ocorre para ventos de Sul, com intensificação das correntes nas seções Sul e Central, e com atenuação das correntes na seção Norte. Com relação à profundidade que as correntes negativas indo para Sul atingem, na seção Norte ela estava restrita à PC na condição sem vento (Figura 14, painel superior), e passa a atingir entre 50 e $100 \mathrm{~m}$ de profundidade na condição de ventos de Sudeste (Figura 27). 

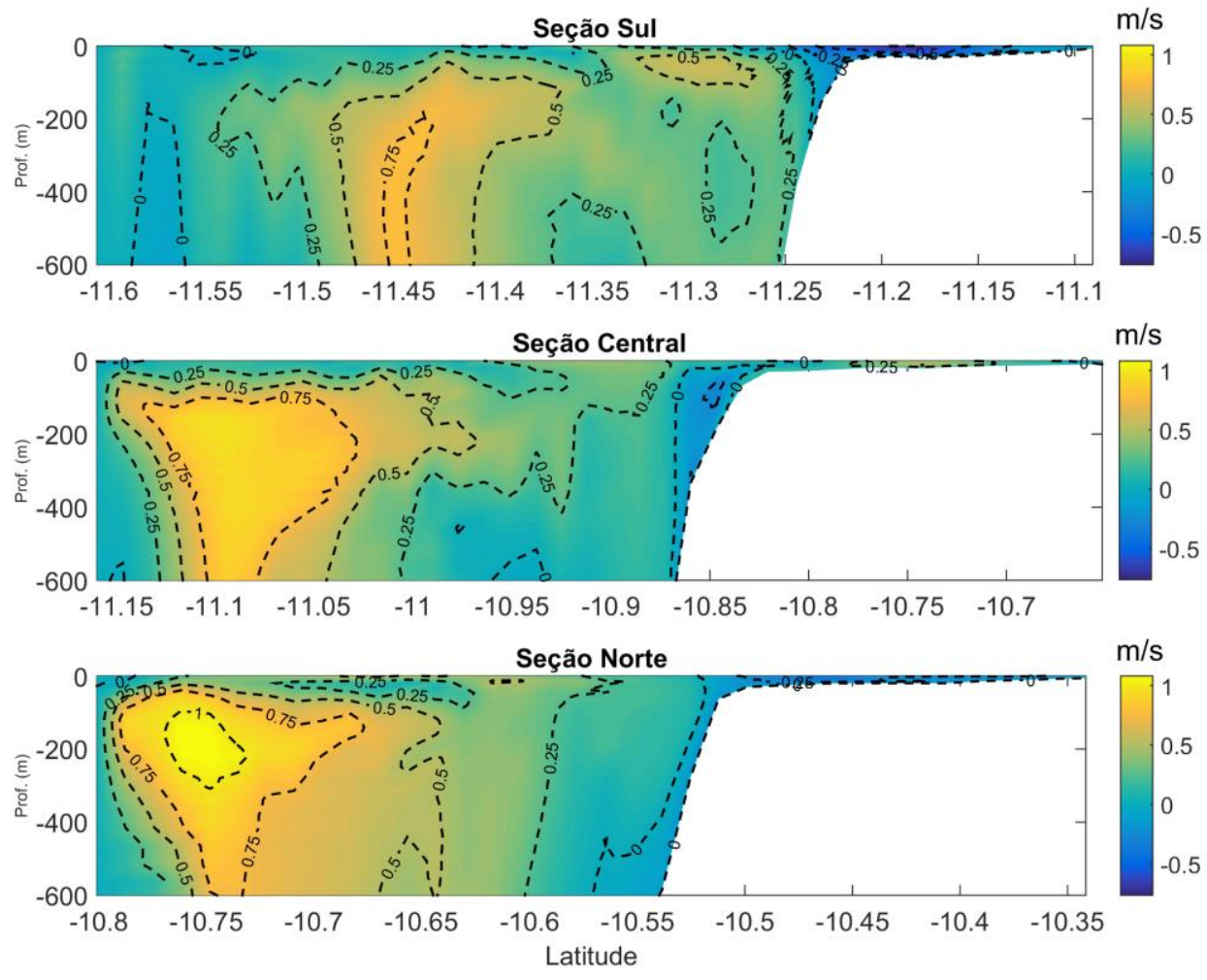

Figura 25 - Corrente no mês de março para ventos de Nordeste, nas seções Sul, Central e Norte.
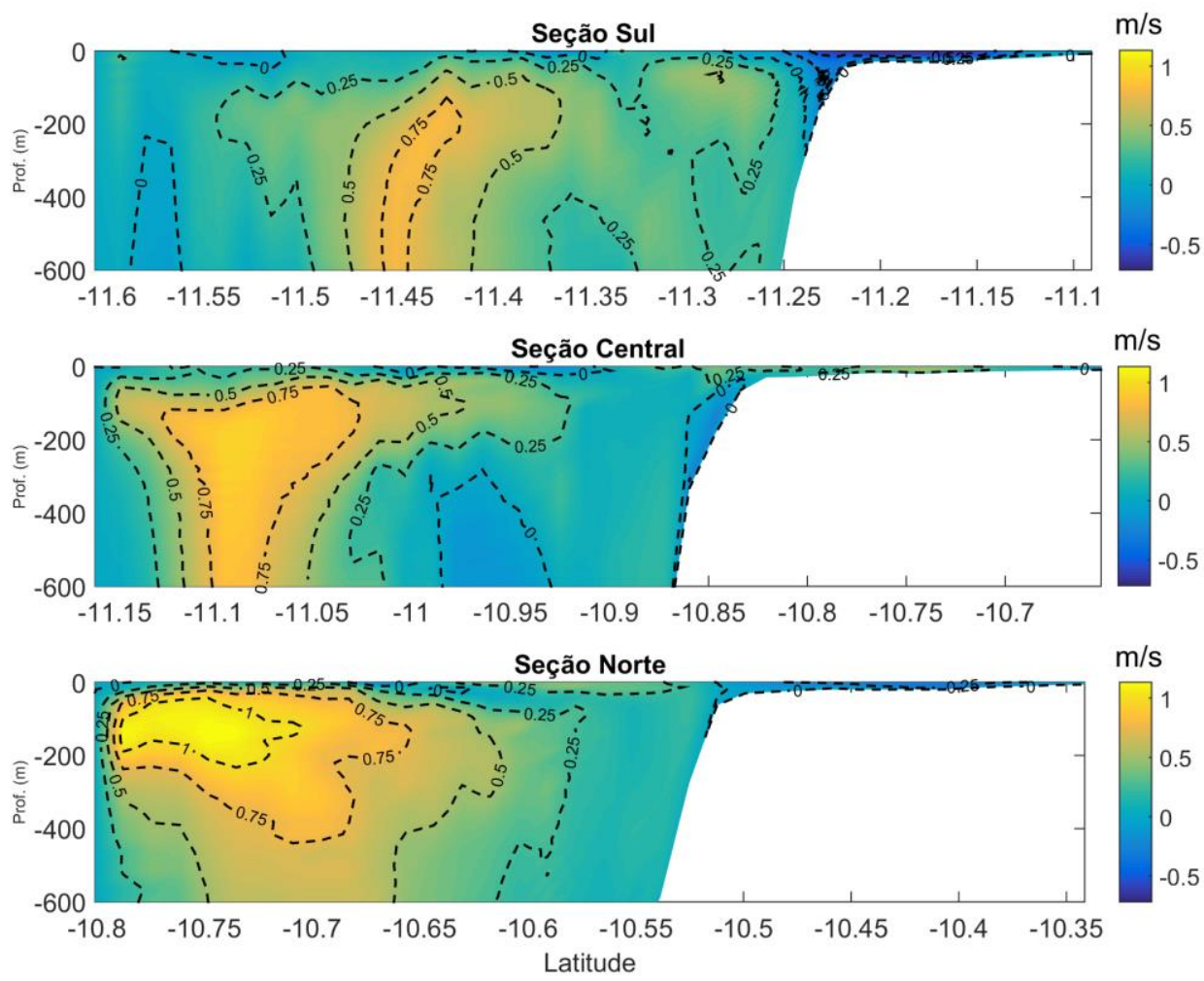

Figura 26 - Corrente no mês de março para ventos de Leste, nas seções Sul, Central e Norte. 

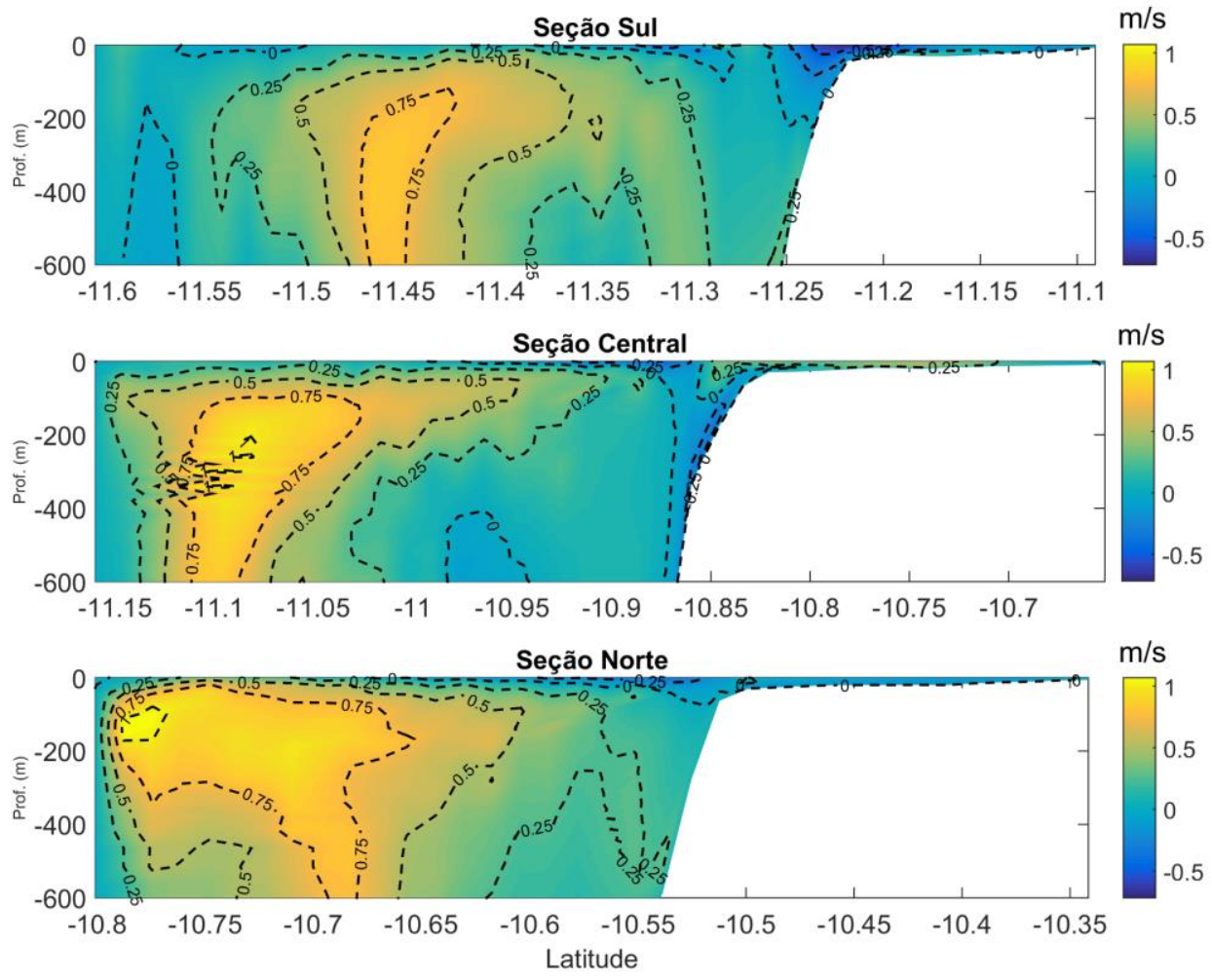

Figura 27 - Corrente no mês de março para ventos de Sudeste, nas seções Sul, Central e Norte.
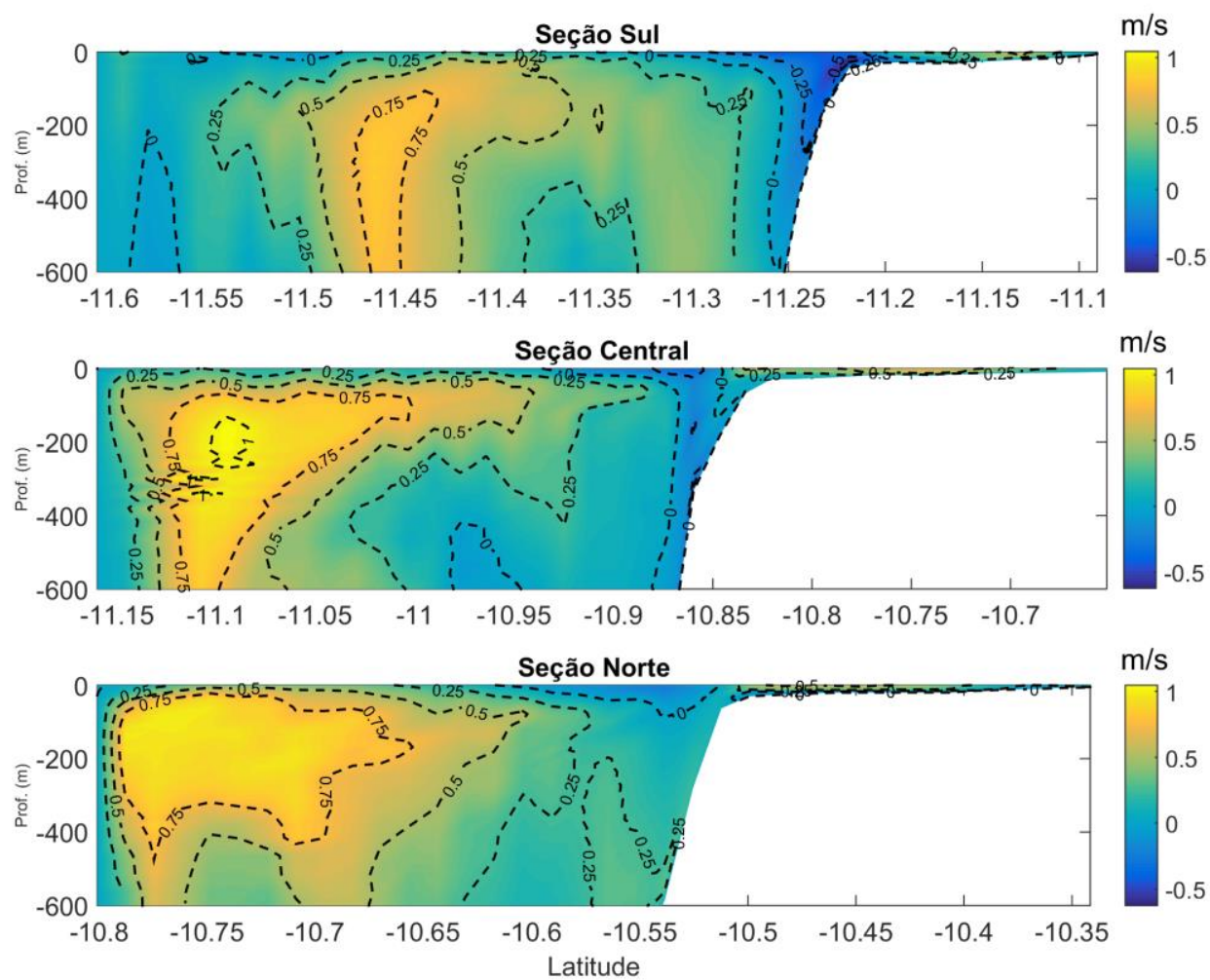

Figura 28 - Corrente no mês de março para ventos de Sul, nas seções Sul, Central e Norte. 

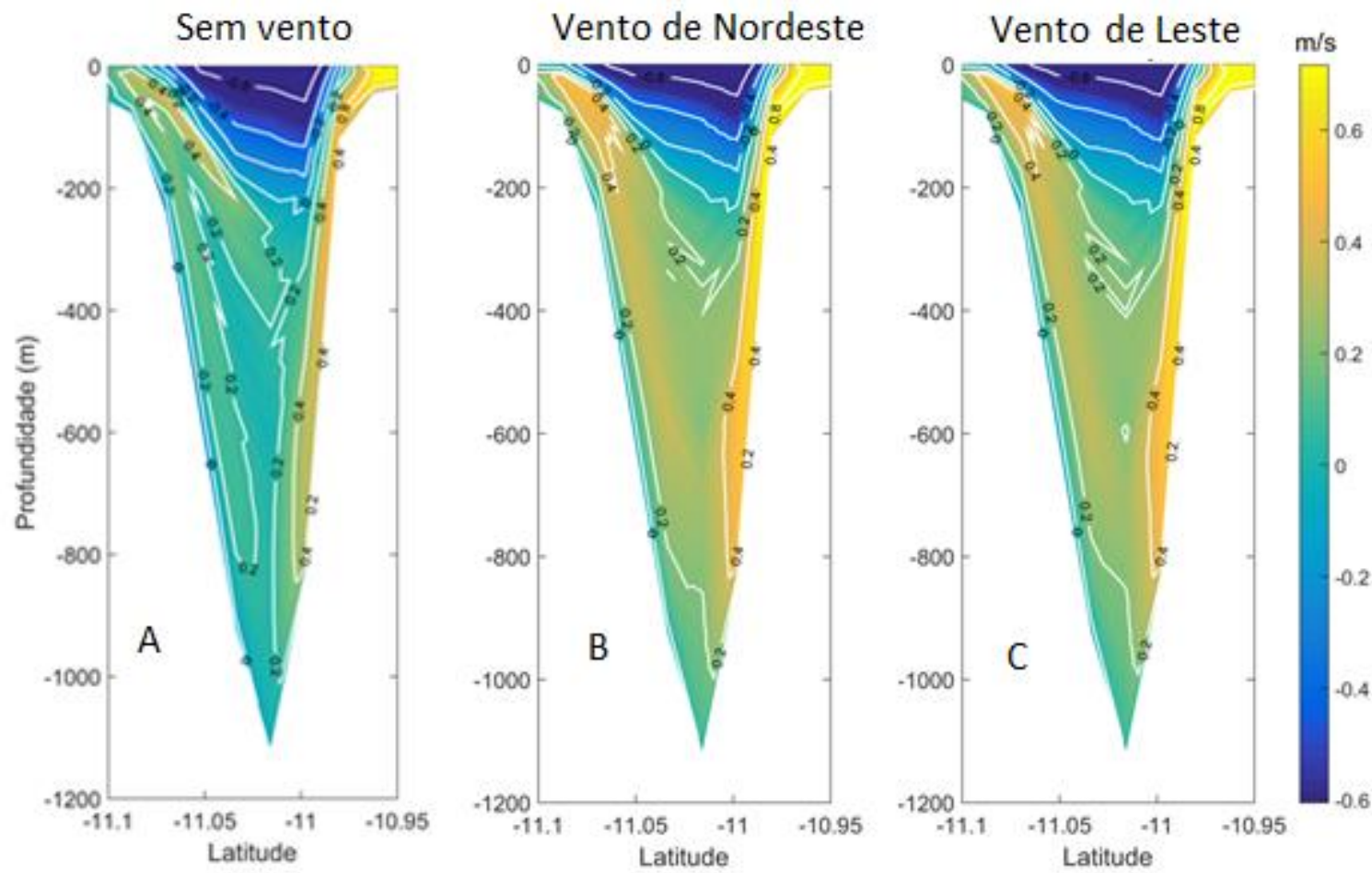

Figura 29 - Correntes nas seções dos cânions de Japaratuba em março, nas condições sem vento (A), vento de Nordeste (B) e vento de Leste (C).
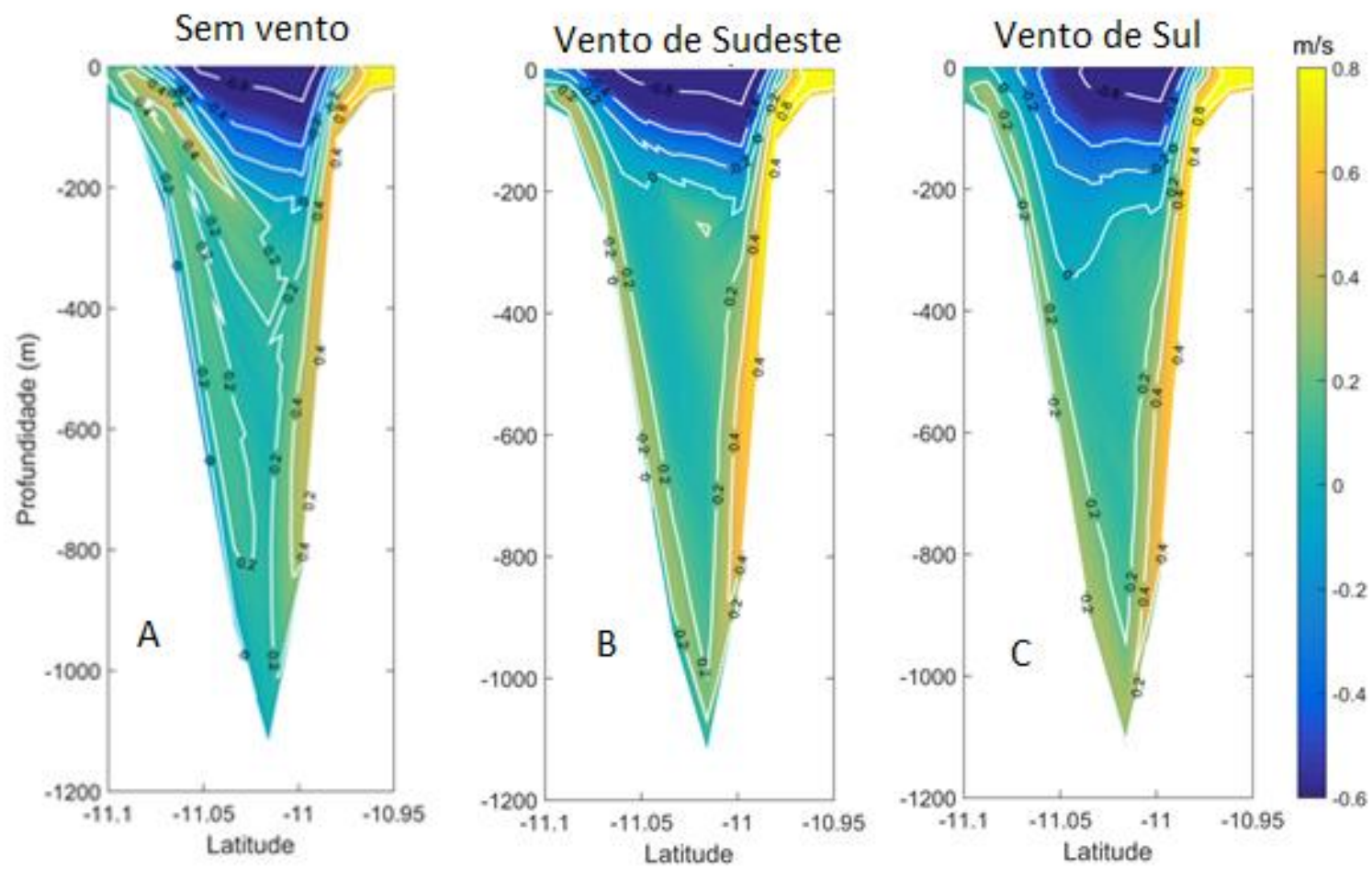

Figura 30 - Correntes nas seções dos cânions de Japaratuba em março, nas condições sem vento $(A)$, vento de Sudeste (B) e vetnto de Sul (C). 
As correntes na seção do cânion de Japaratuba para as condições sem vento (Figura 29A), ventos de Nordeste (Figura 29B), de Leste (Figura 29C), de Sudeste (Figura 30B) e de Sul (Figura 30C) são predominantemente positivas (da costa em direção a regiões mais profundas), excetuando até $200 \mathrm{~m}$ de profundidade, na parte central do cânion, onde ocorrem fluxos negativos, variando de - 0,80 a $0,80 \mathrm{~m} . \mathrm{s}^{-1}$, sendo que os valores mais negativos ocorrem perto da superfície, e os mais positivos ocorrem nas bordas do cânion. Já no cânion do São Francisco (Figura 31 e Figura 32) as correntes são predominantemente negativas, exceto na região central do cânion até $50 \mathrm{~m}$ de profundidade e a borda norte, com valores variando de - 0,5 a $0,2 \mathrm{~m} \cdot \mathrm{s}^{-1}$, com os valores mais negativos na região central do cânion entre 50 e 350 $\mathrm{m}$ de profundidade, e os valores máximos na superfície e na borda norte do cânion.

Ao adicionarmos tanto vento de Nordeste, quanto vento de Leste (Figura 29), ocorre uma intensificação das correntes positivas no cânion de Japaratuba na região central, entre 300 e $800 \mathrm{~m}$ de profundidade, e também na borda sul do cânion. Já ao adicionarmos tanto vento de Sudeste, quanto vento de Sul (Figura 30), ocorre a atenuação das correntes positivas na borda sul cânion de Japaratuba e também abaixo de $200 \mathrm{~m}$ de profundidade na região central, sendo mais evidenciado para 0 cenário de ventos de Sul.

Já no cânion do São Francisco, as correntes positivas na borda norte para a condição sem vento (Figura 31) diminuem ao adicionar ventos de Nordeste e de Leste, o que torna o fluxo mais negativo. Ao adicionarmos vento de Sudeste ou de Sul (Figura 32), as correntes negativas são amenizadas, ou seja, diminui o fluxo vindo de regiões mais profundas em direção ao cânion. Além disso, aumenta a intensidade das correntes positivas na borda norte do cânion. 

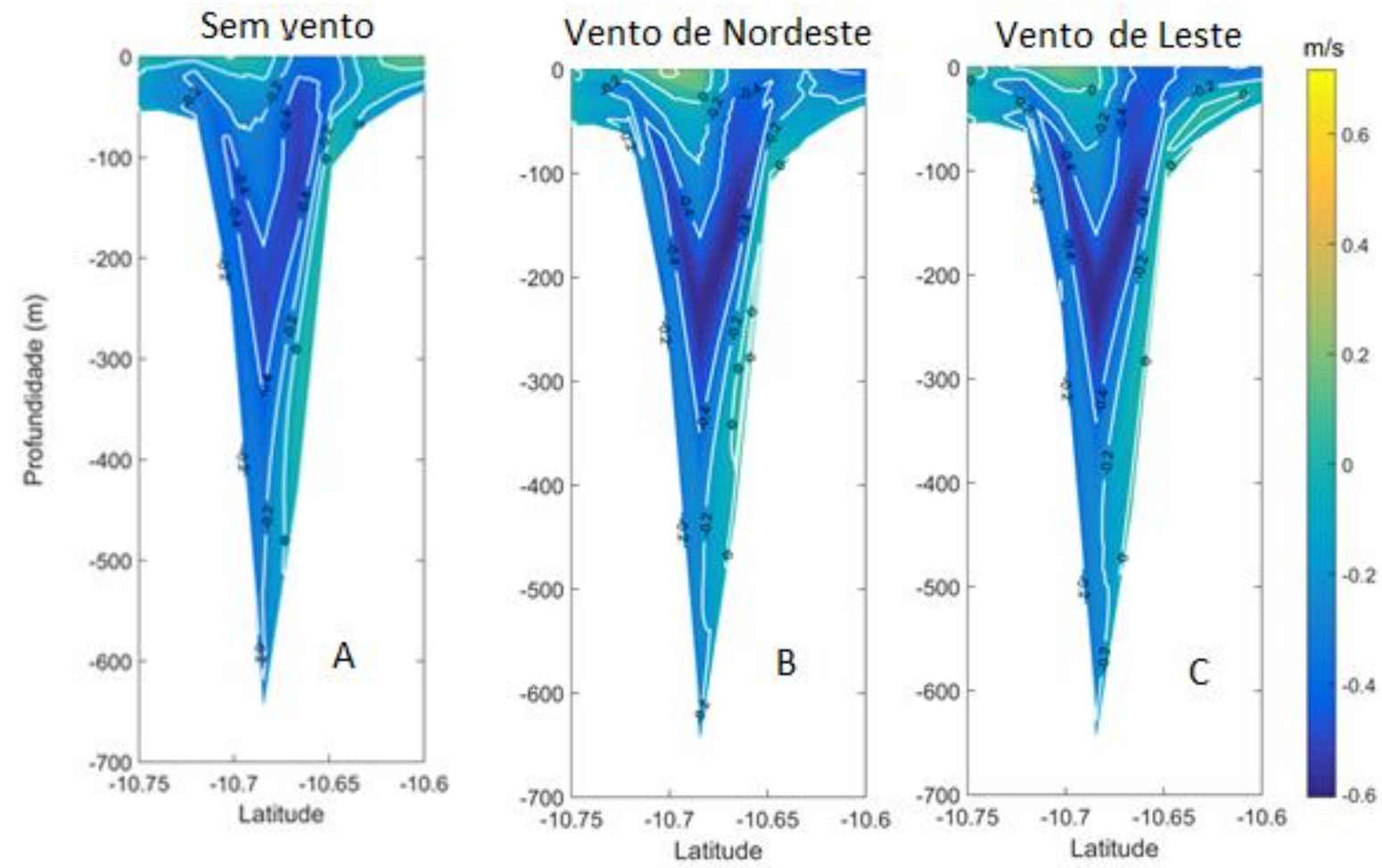

Figura 31 - Correntes nas seções do cânion do São Francisco em março, nos cenários sem vento $(A)$, vento de Nordeste (B) e vento de Leste (C).
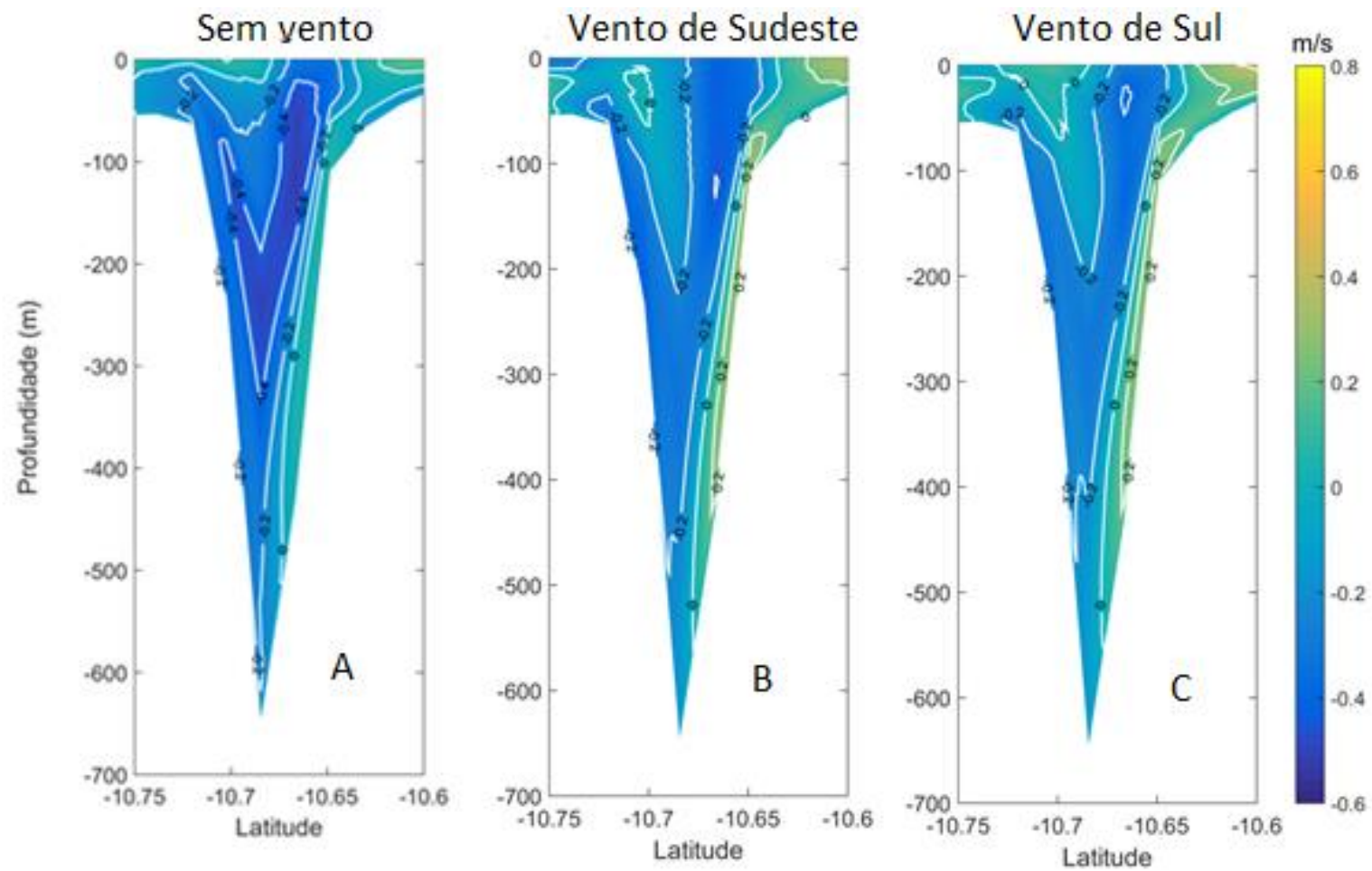

Figura 32 - Correntes nas seções dos cânions do São Francisco em março, nos cenários sem vento $(A)$, vento de Sudeste (B) e vento de Sul (C). 
O cálculo do transporte de volume foi feito através da integração a cada $50 \mathrm{~m}$, utilizando as correntes que atravessam as seções (Figura 8). Para o cânion de Japaratuba (Figura 33), o transporte é praticamente o mesmo para os ventos de Nordeste e de Leste, sendo positivo para todas as profundidades maiores que $50 \mathrm{~m}$. Para a condição de ventos de Sudeste, o transporte é negativo até $150 \mathrm{~m}$ de profundidade, e é positivo para regiões mais profundas. Para ventos de Sul, o perfil do transporte é semelhante ao do vento de Sudeste, com a diferença de ser negativo até $200 \mathrm{~m}$ de profundidade, sendo positivo para maiores profundidades, mas menos intenso que a condição de vento de Sudeste.

Para o cânion do São Francisco (Figura 33), o transporte é praticamente o mesmo para os ventos de Nordeste e de Leste, sendo negativo para todas as profundidades, e ligeiramente maior para ventos de Leste até $50 \mathrm{~m}$ de profundidade. Para as condições de ventos de Sudeste e de Sul, o transporte é praticamento o mesmo, sendo negativo para todas as profundidades maiores que $50 \mathrm{~m}$, sendo mais negativos que as condições anteriores.
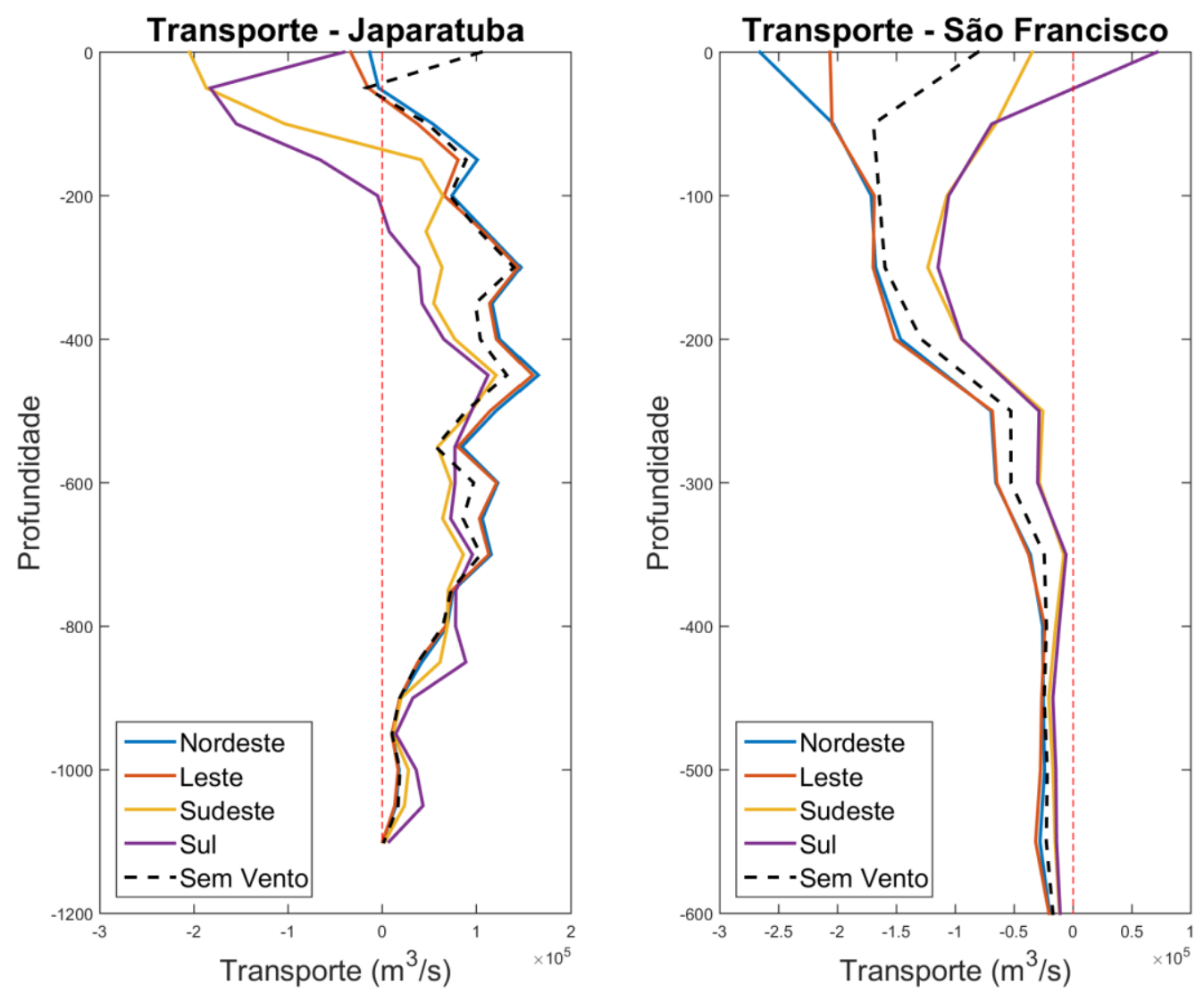

Figura 33 - Transporte em função da profundidade nas seções dos cânions de Japaratuba e São Francisco para o mês de março para as condições de vento de Nordeste, Leste, Sudeste e Sul. 


\subsection{3 - Julho: Cenários com ventos de Nordeste, Leste, Sudeste e Sul (B)}

Os campos mensais de temperatura e salinidade utilizados no mês de julho estão apresentados na Figura 34, para os cânions de Japaratuba e do São Francisco, nas seções mostradas na Figura 8. No cânion de Japaratuba (Figura 34), a salinidade varia de 34,5 até 37 , sendo mais salino em regiões mais rasas, enquanto a temperatura cai de $25^{\circ} \mathrm{C}$ a $100 \mathrm{~m}$ de profundidade até $5^{\circ} \mathrm{C}$ no fundo. Já no cânion de Sâo Francisco, a salinidade vai de 34,5 até 37, também mais salino em regiões mais rasas. Já a temperatura varia de $8^{\circ} \mathrm{C}$ a $25^{\circ} \mathrm{C}$.

A circulação para as profundidades 100, 200, 300 e 400 m, nas condições de ventos constantes (B) para ventos de Nordeste (Figura 35), Leste (Figura 36), Sudeste (Figura 37) e Sul (Figura 38) apresentam-se bastante semelhantes. As correntes mais intensas foram obtidas para a condição de ventos de Sul e Sudeste, enquanto as menos intensas foram para ventos de Nordeste. Em todas as situações, as correntes são predominantemente para Nordeste e Leste, com valores máximos chegando a 1,2 m.s ${ }^{-1}$. Os fluxos mais intensos ocorrem afastados da costa.
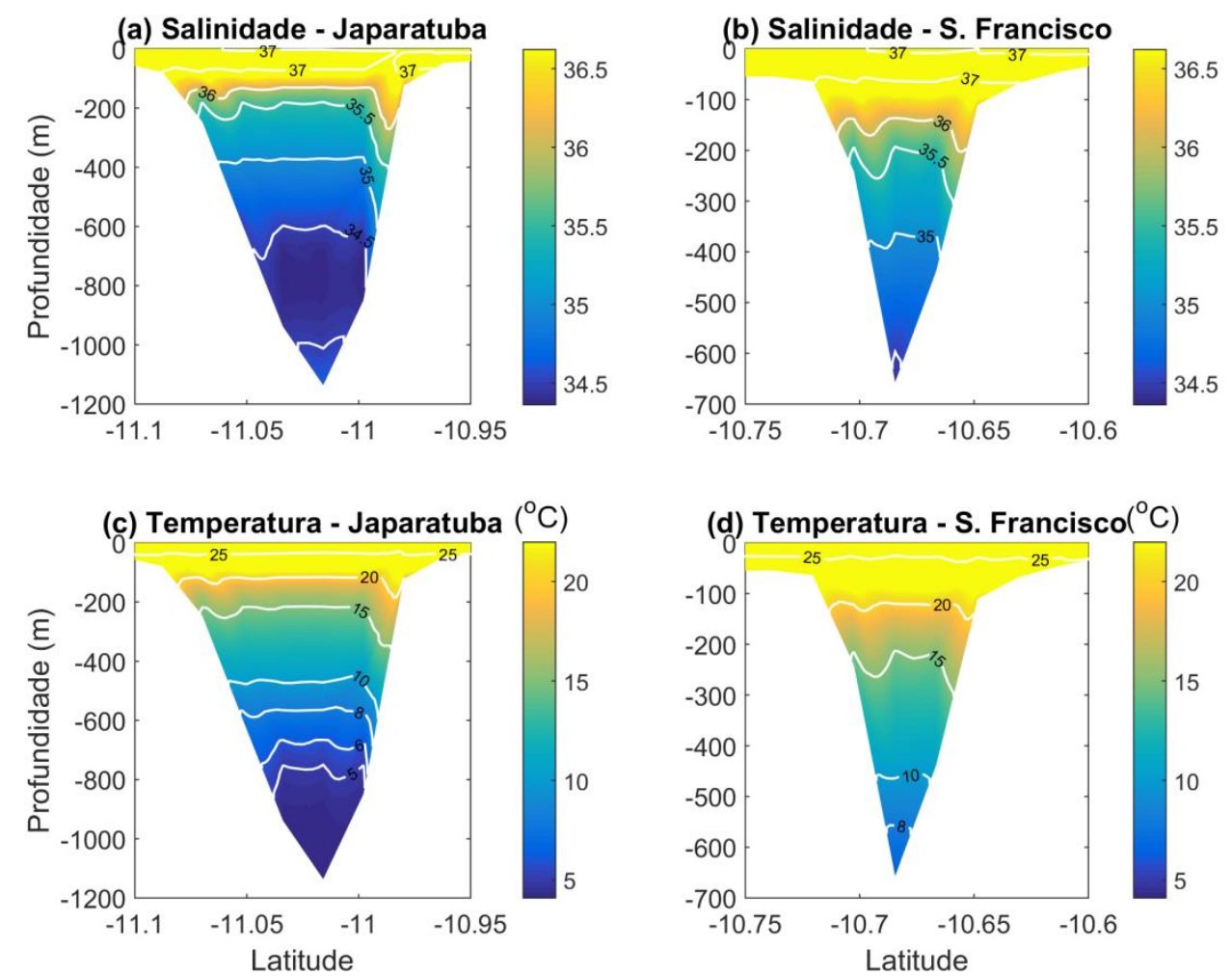

Figura 34 - Salinidade e temperatura nas seções dos cânions de Japaratuba e do São Francisco em julho. 

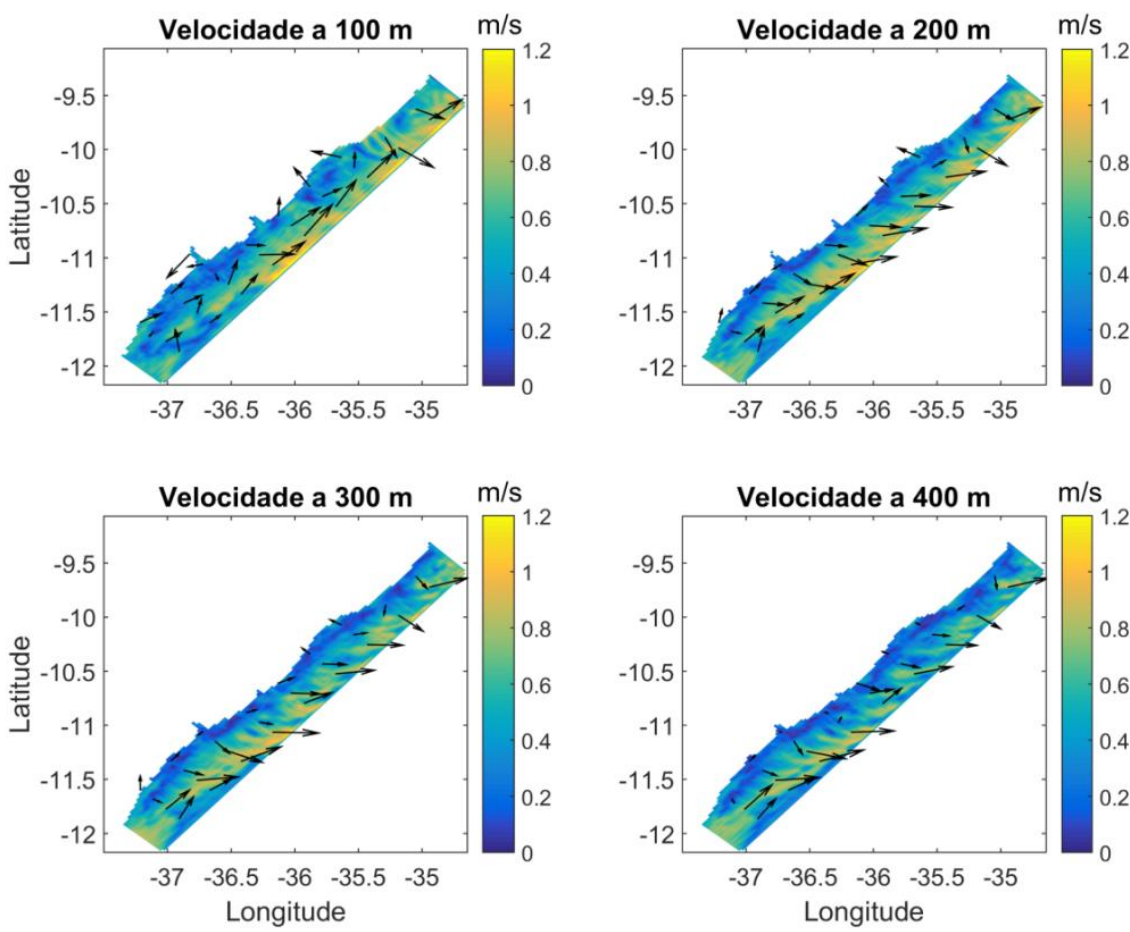

Figura 35 - Circulação na área de estudo para julho e vento de Nordeste, a 100, 200, 300 e 400 m.
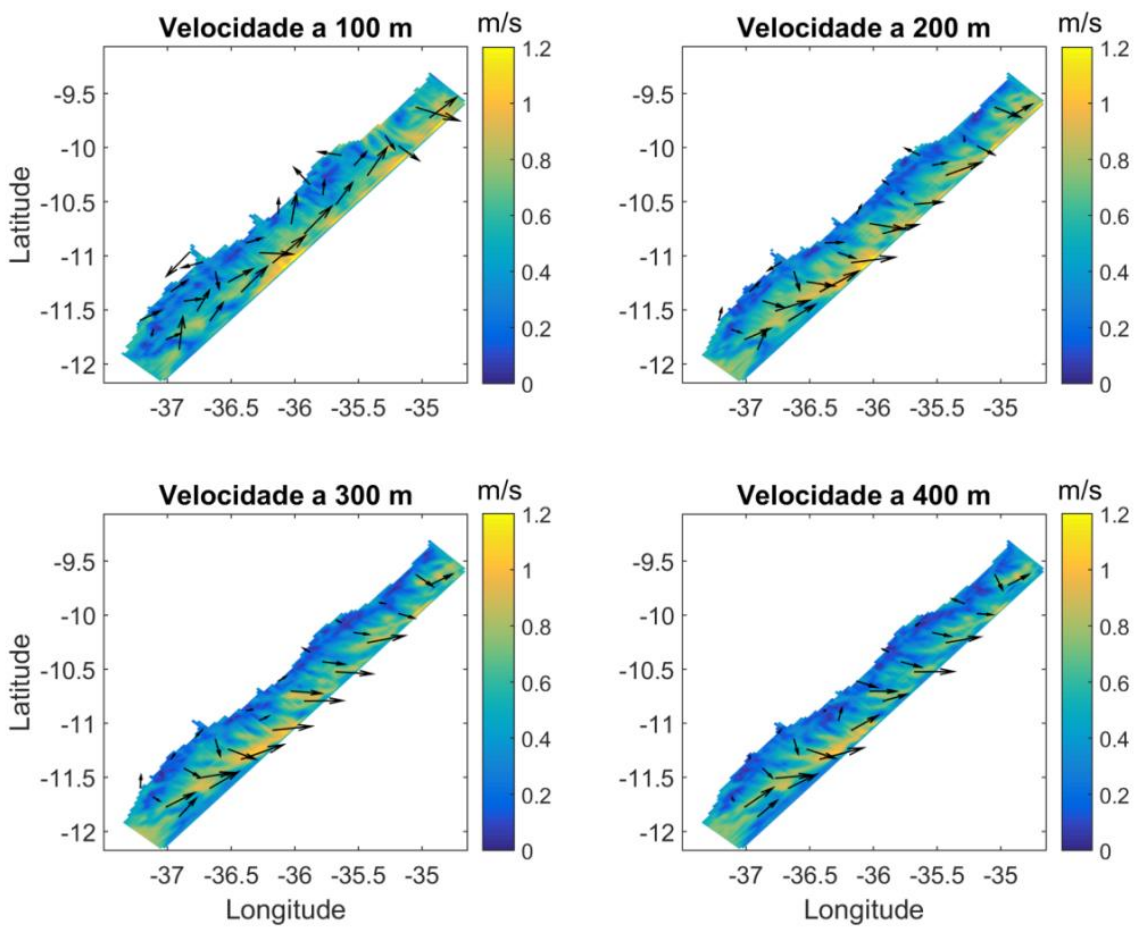

Figura 36 - Circulação na área de estudo para julho e vento de Leste, a 100, 200, 300 e 400 m. 

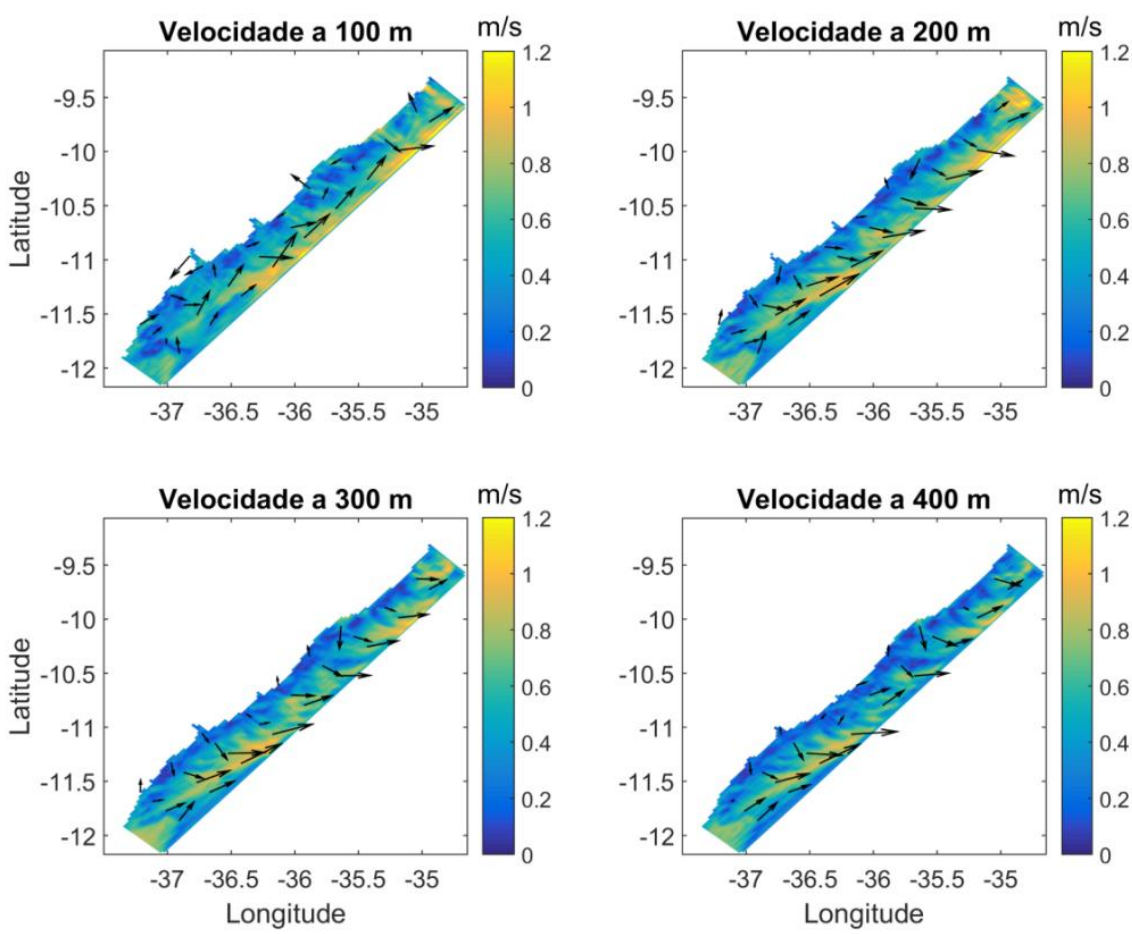

Figura 37 - Circulação na área de estudo para julho e vento de Sudeste, a 100, 200, 300 e 400 m.
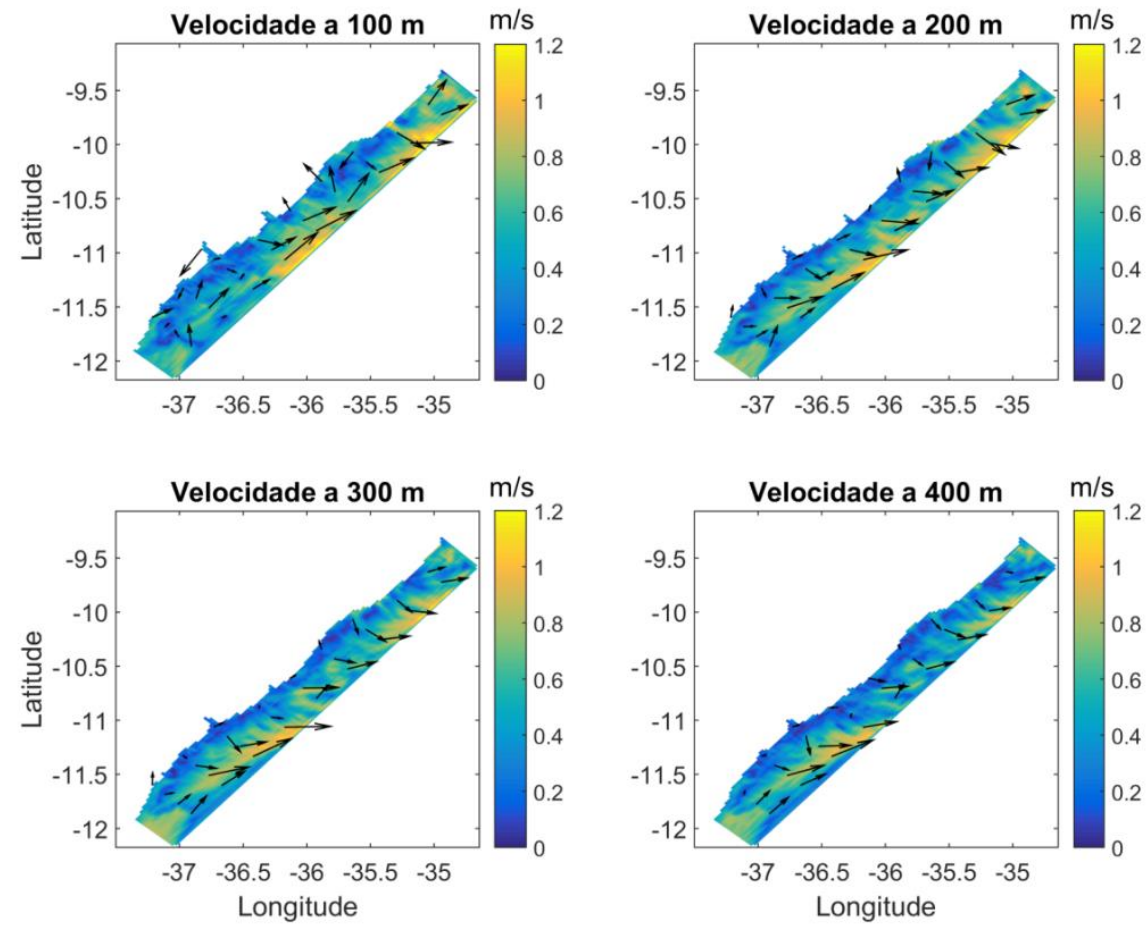

Figura 38 - Circulação na área de estudo para julho e vento de Sul, a 100, 200, 300 e 400 m. 


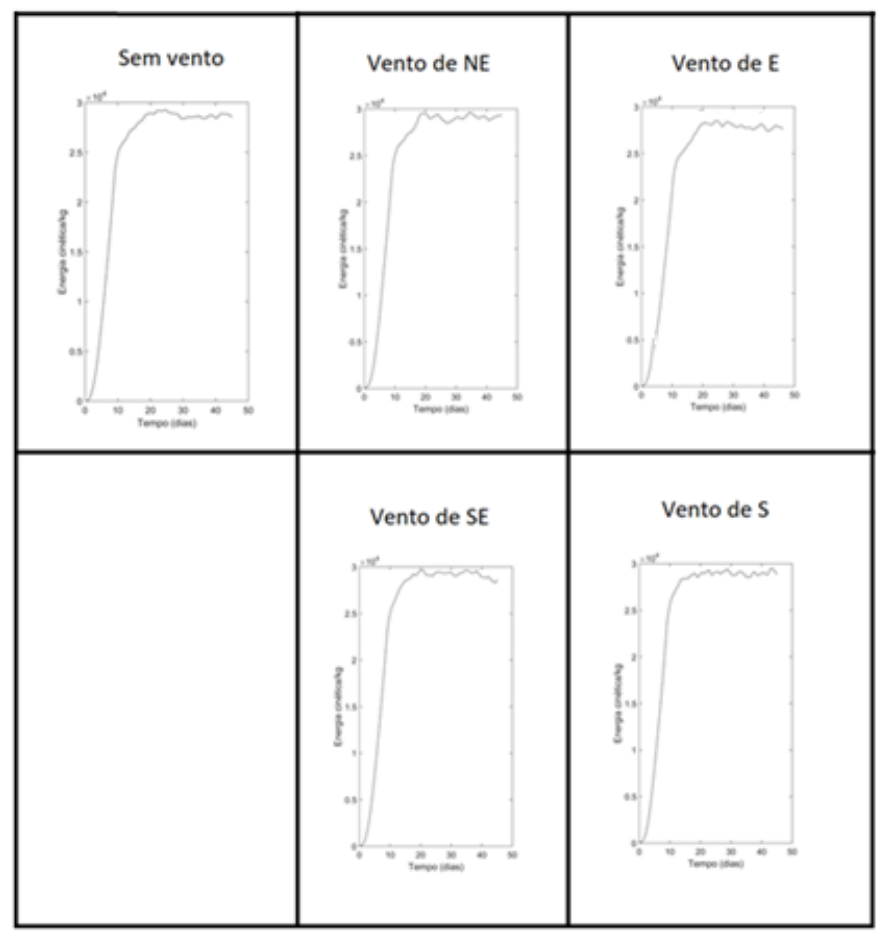

Figura 39 - Energia cinética em função do tempo para o mês de julho, nas condições sem vento,e com ventos de NE, E, SE e $S$.

Na Figura 39 são apresentadas a energia cinética total, em função do tempo, para o mês de julho, para as condições sem vento, e de ventos de Nordeste, Leste, Sudeste e Sul. Os comportamentos são semelhantes em todos os cenários, com aumento rápido até aproximadamente 12 dias, e posteriormente mantem seus valores abaixo de um patamar de 2,8 a $3 \times 10^{4} \mathrm{~J} / \mathrm{kg}$.

As velocidades nas seções perpendiculares à costa (Figura 8) para as condições sem vento (Figura 14, painel central), ventos de Nordeste (Figura 40), de Leste (Figura 41), de Sudeste (Figura 42) e de Sul (Figura 43), para o mês de Julho, apresentam algumas semelhanças. Observa-se um predomínio de correntes positivas, ou seja, para Nordeste. Há fluxos negativos na região de plataforma continental, indicando correntes para Sudoeste. Também pode ser observado que o núcleo da corrente ocorre em subsuperfície, localizado entre 100 e 300 m, com valores máximos variando entre 0,8 e 1,2 m.s. 

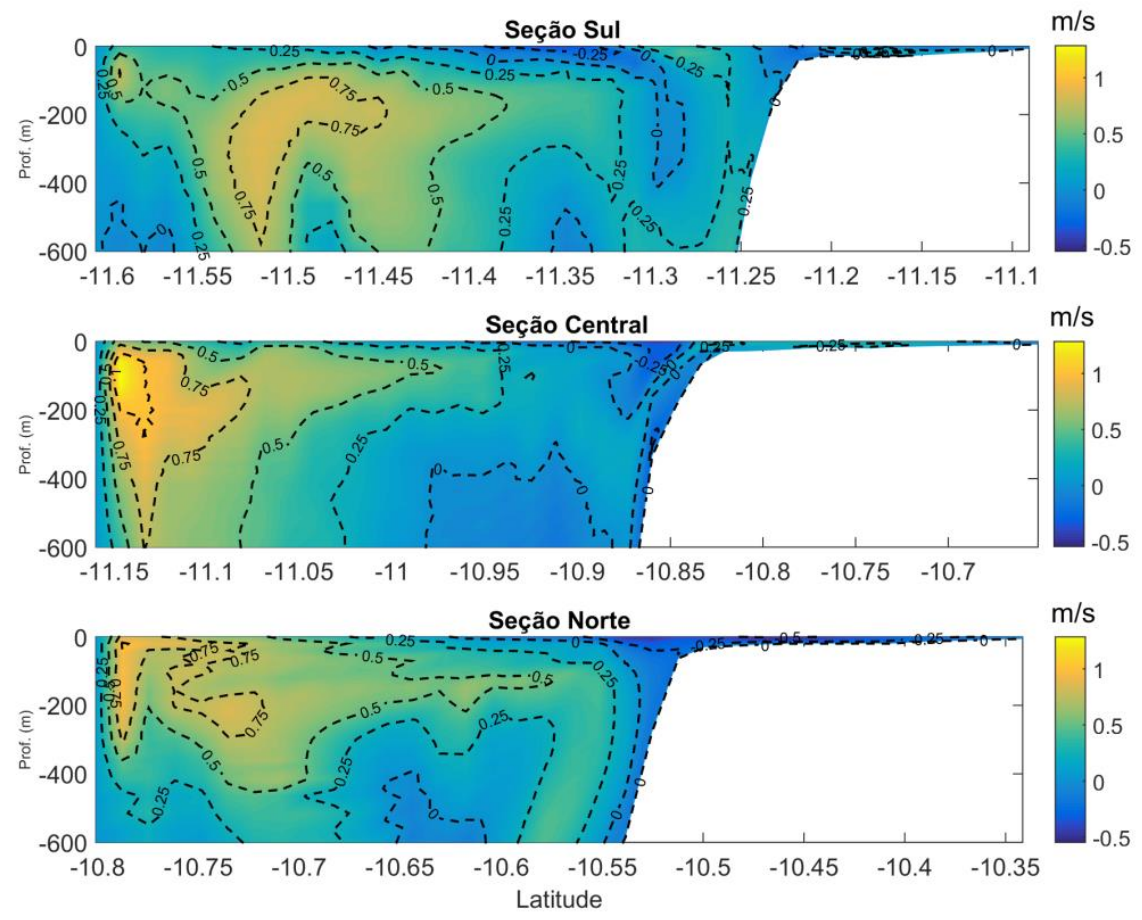

Figura 40 - Corrente no mês de julho para ventos de Nordeste, nas seções Sul, Central e Norte.
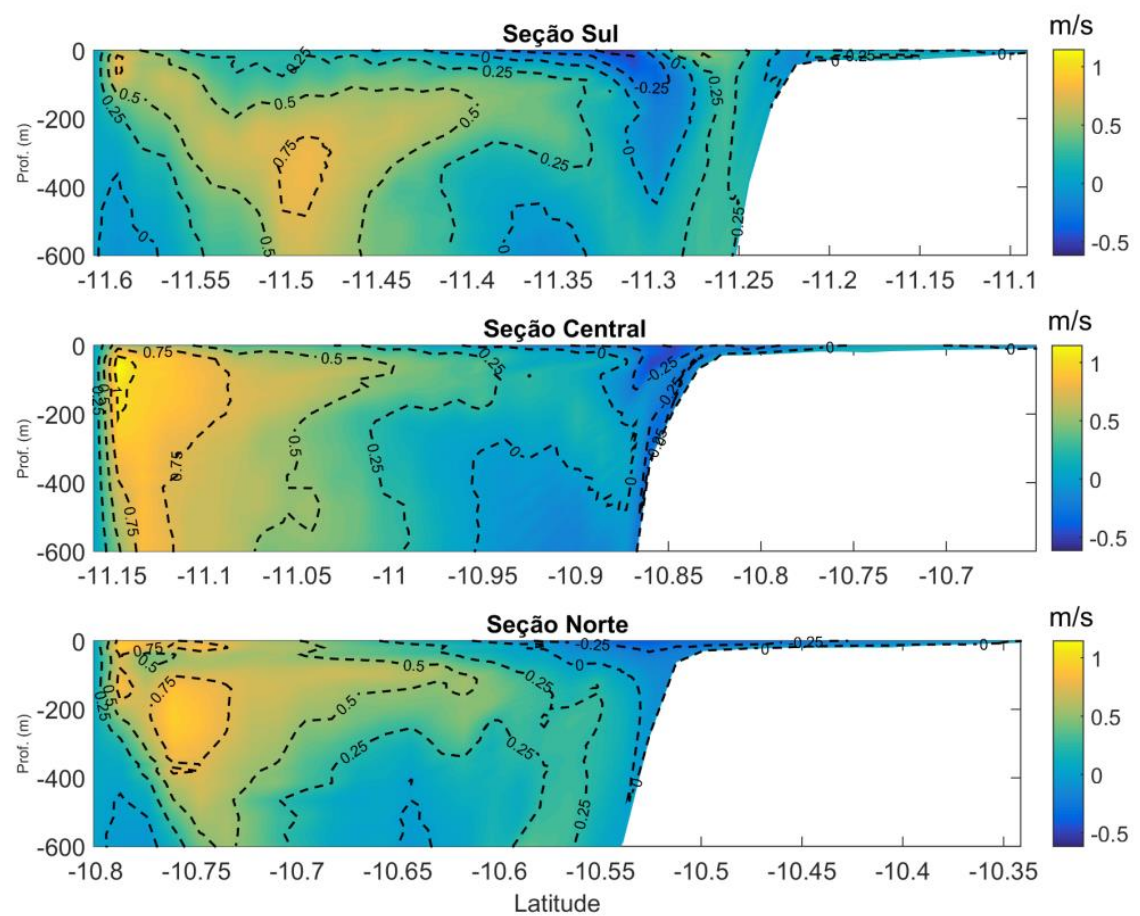

Figura 41 - Corrente no mês de julho para ventos de Leste nas seções Sul, Central e Norte. 

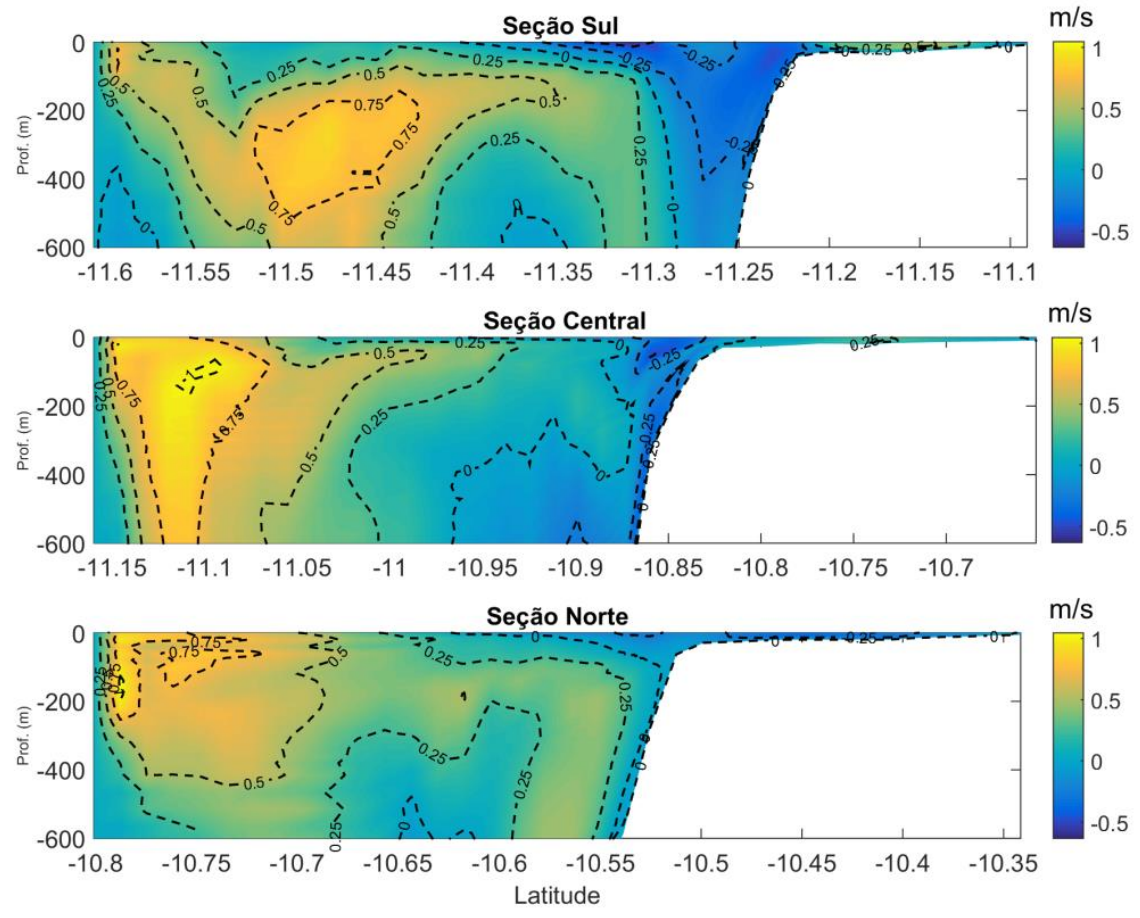

Figura 42 - Corrente no mês de julho para ventos de Sudeste, nas seções Sul, Central e Norte.
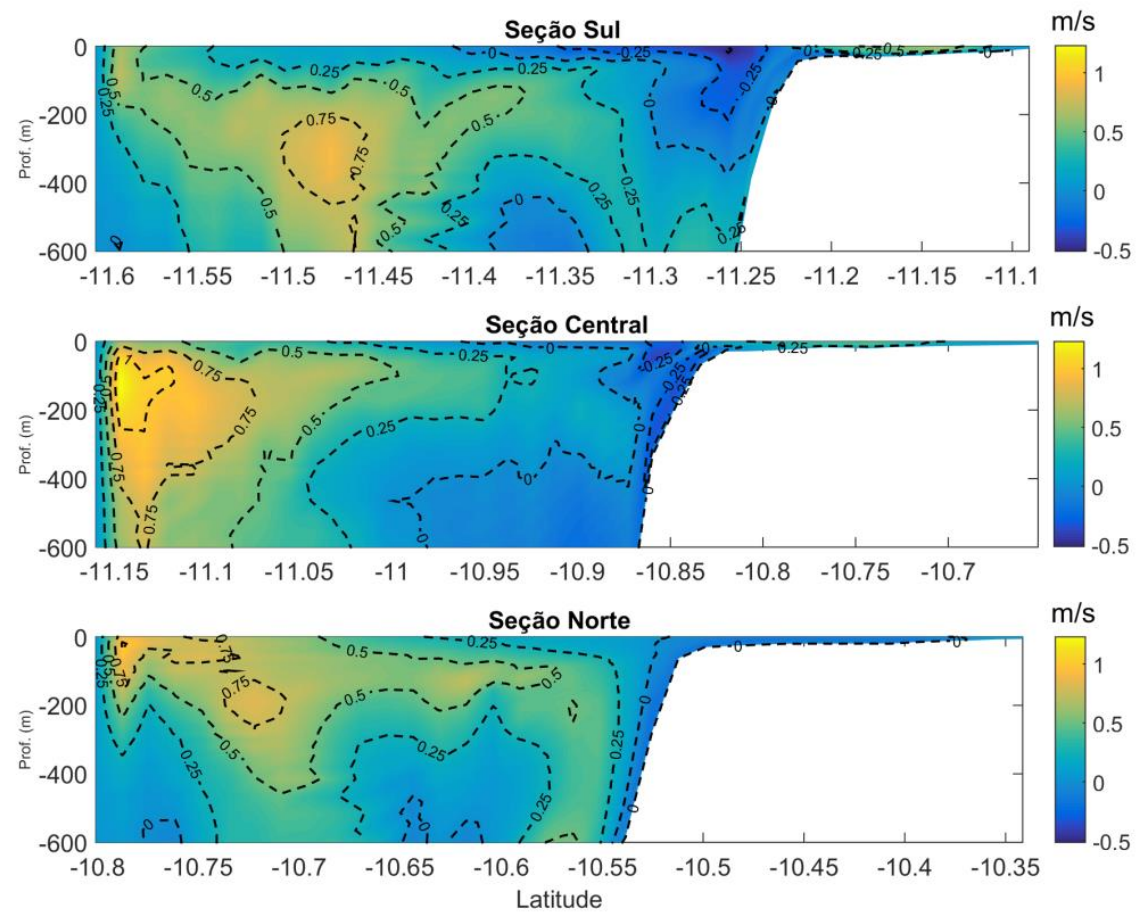

Figura 43 - Corrente no mês de julho para ventos de Sul nas seções Sul, Central e Norte. 
Se compararmos as condições sem vento (A) (Figura 14, painel central) em relação às condições com vento $(\mathrm{B})$, são observadas algumas alterações ao adicionar o vento dependendo da direção.

Ao adicionar vento de Nordeste e de Leste, podemos observar uma diminuição das correntes em todas as seções, com o núcleo na seção Central entre 100 e 200 m de profundidade, se afastando da costa. Também há um aumento da região de fluxos negativos próximo à costa nas 3 seções, que fica mais evidente na seção Norte, que no cenário sem vento, as correntes negativas estavam restritas à PC, enquanto que no cenário de vento de Nordeste, elas chegaram a $600 \mathrm{~m}$ de profindidade, e no cenário de ventos de Leste chagam a $500 \mathrm{~m}$.

Quando foi adicionado vento de Sudeste e de Sul, também houve uma atenuação da corrente nas seções Central e Sul. Porém, na seção Norte, houve intensificação das correntes próximas ao núcleo da SNB, ocorrendo em subsuperfície por volta de $300 \mathrm{~m}$ de profundidade, e passando a $100 \mathrm{~m}$ na seção Central. Porém, também houve aumento da região com correntes negativas próximo à costa, com maior destaque para a seção Norte, que para a condição sem vento apresentou correntes negativas perto da costa restrita à $\mathrm{PC}$, enquanto que para ventos de Sudeste e Sul ultrapassa os $600 \mathrm{~m}$ de profundidade.

As correntes na seção do cânion de Japaratuba para as condições sem vento (Figura 44A), ventos de Nordeste (Figura 44B), de Leste (Figura 44C), de Sudeste (Figura 45B) e de Sul (Figura 45C) são predominantemente positivas (da costa em direção a regiões mais profundas), excetuando até $300 \mathrm{~m}$ de profundidade, na parte central do cânion e na borda sul, onde ocorrem fluxos negativos, variando de - 0,80 a $0,80 \mathrm{~m} \cdot \mathrm{s}^{-1}$, sendo os valores mais negativos próximos da superfície na região central do cânion, e os mais positivos ocorrem ao longo da borda Norte do cânion.

Ao adicionarmos tanto vento de Nordeste (Figura 44B), de Leste (Figura 44B) e de Sudeste (Figura 45B), ocorre uma diminuição das correntes positivas no cânion de Japaratuba em sua borda sul, até $200 \mathrm{~m}$ de profundidade, onde a área com velocidades positivas diminui de tamanho, e a área de velocidades negativas aumenta de tamanho. Na borda Norte, há intensificação das correntes positivas ao adicionar essas condições de vento.

Já ao adicionarmos vento de Sul (Figura 45B), apresenta-se um perfil diferente das outras condições de vento. Para o cenário sem vento, a área onde 
ocorrem correntes positivas na região superficial próximo à borda Sul do cânion de Japaratuba aumentou de tamanho ao adicionar vento de Sul, e passou a ocupar a área onde havia um núcleo de corrente negativa no centro do cânion, fazendo com que este núcleo negativo afundasse. Isso aumentou as correntes nas regiões mais superficiais até $100 \mathrm{~m}$ de profundidade, e diminuiu as correntes abaixo de $150 \mathrm{~m}$.

As correntes no cânion do São Francisco são predominantemente negativas (Figura 46 e Figura 47), excetuando a região da borda Norte abaixo de $50 \mathrm{~m}$ de profundidade, com valores variando de $-0,5$ a $0,2 \mathrm{~m} \cdot \mathrm{s}^{-1}$, com os valores mais negativos na região central do cânion entre a superfície e $200 \mathrm{~m}$ de profundidade, e valores mais positivos na borda Norte do cânion.

Ao adicionar ventos de Nordeste (Figura 46B) e de Leste (Figura 46C), as correntes no cânion do São Francisco ficaram mais negativas entre a superfície e $200 \mathrm{~m}$ de profundidade, e as correntes positivas ao longo da borda Norte do cânion se intensificaram. Assim, com a adição de vento de Nordeste e Leste intensificou o fluxo nos dois sentidos, de regiões mais profundas em direção ao cânion, e na direção oposta. Já ao adicionar vento de Sudeste (Figura 47B) e de Sul (Figura $47 C)$, correntes negativas na borda Sul e abaixo de $300 \mathrm{~m}$ de profundidade passaram a ser positivas, e as correntes positivas na borda Norte do cânion se intensificaram. 

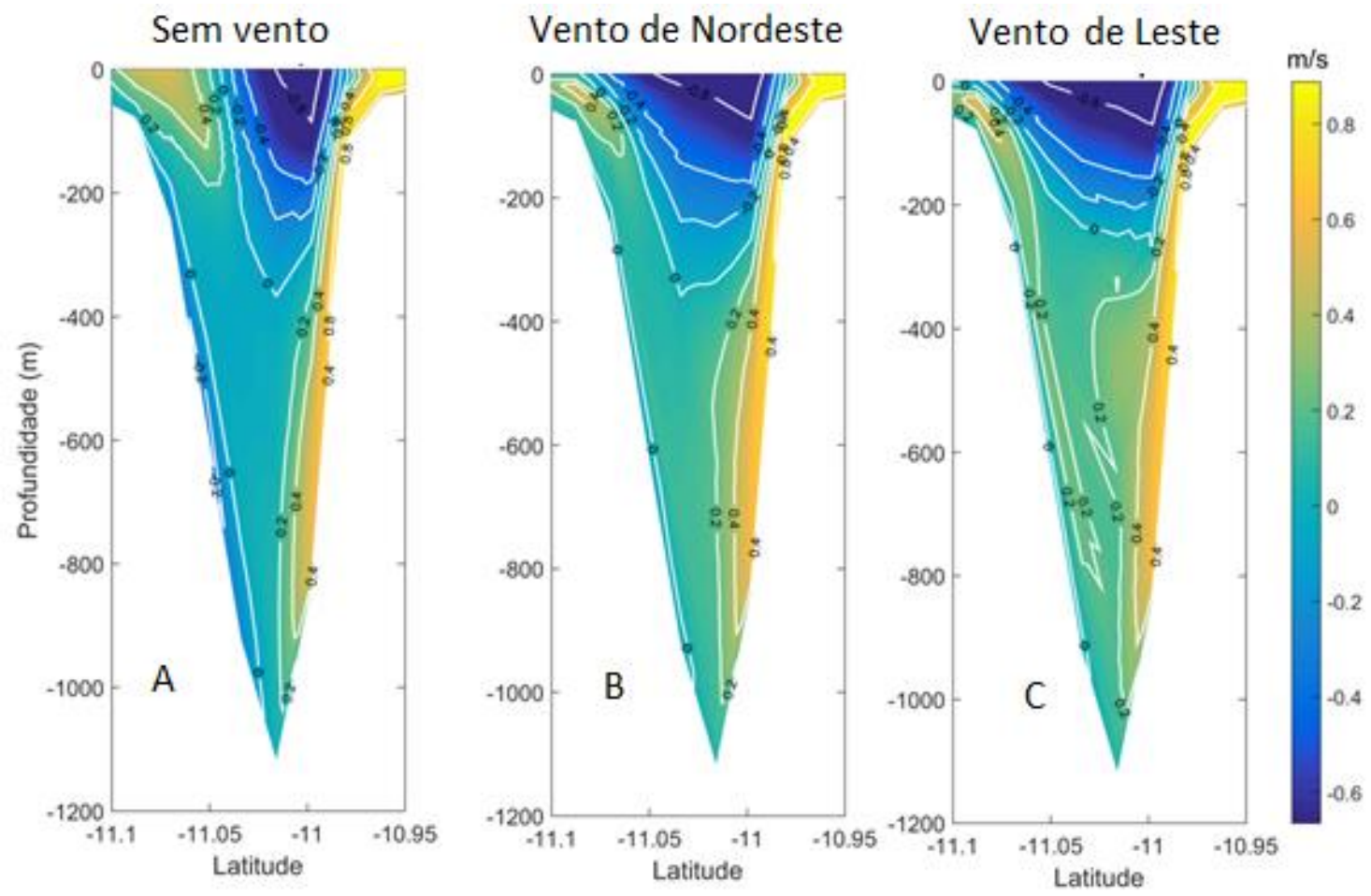

Figura 44 - Correntes nas seções do cânion de Japaratuba em julho, nos cenários sem vento (A), vento de Nordeste (B) e vento de Leste (C).
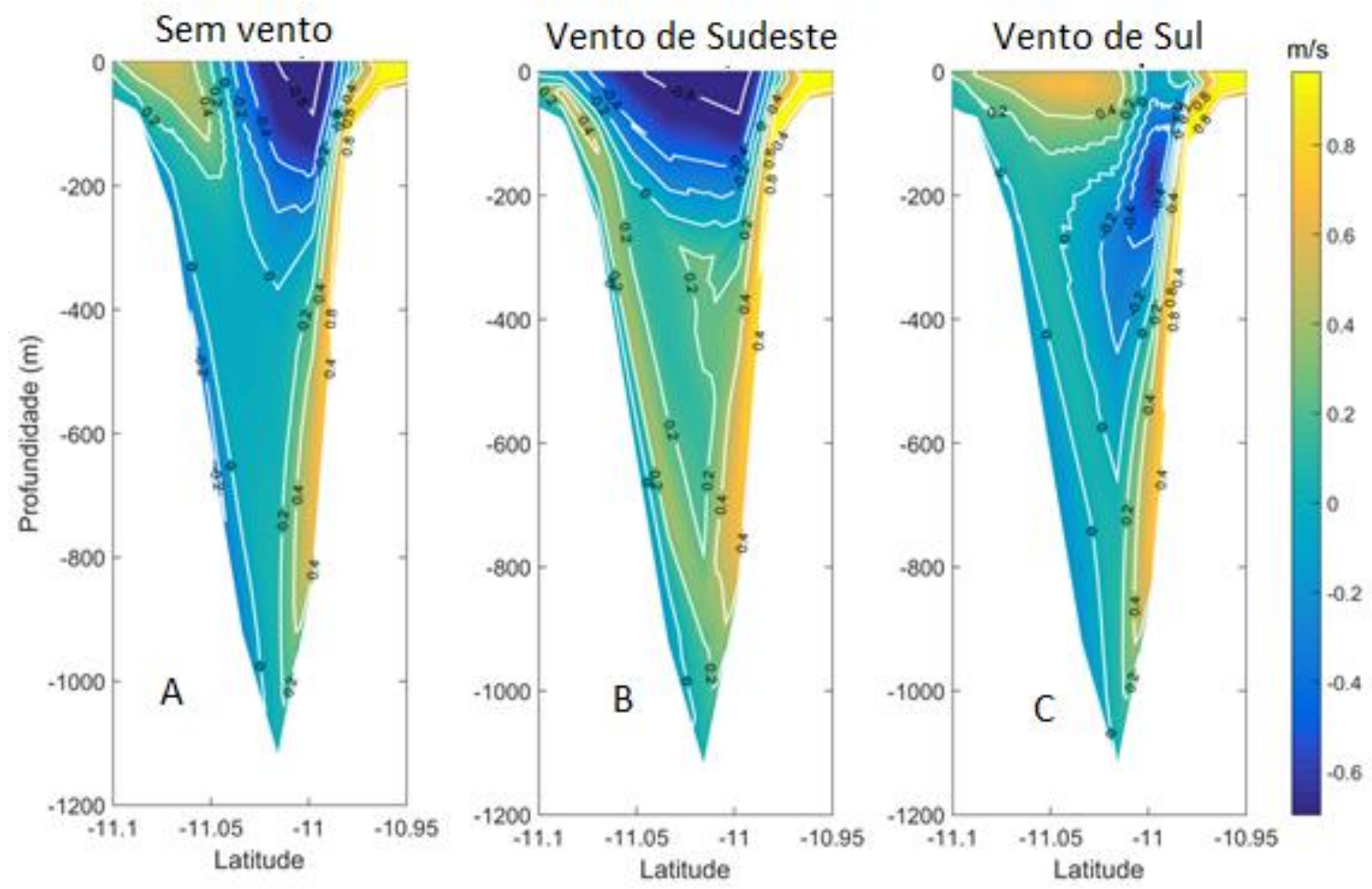

Figura 45 - Correntes nas seções do cânion de Japaratuba em julho, nos cenários sem vento (A), vento de Sudeste (B) e vento de Leste (C). 

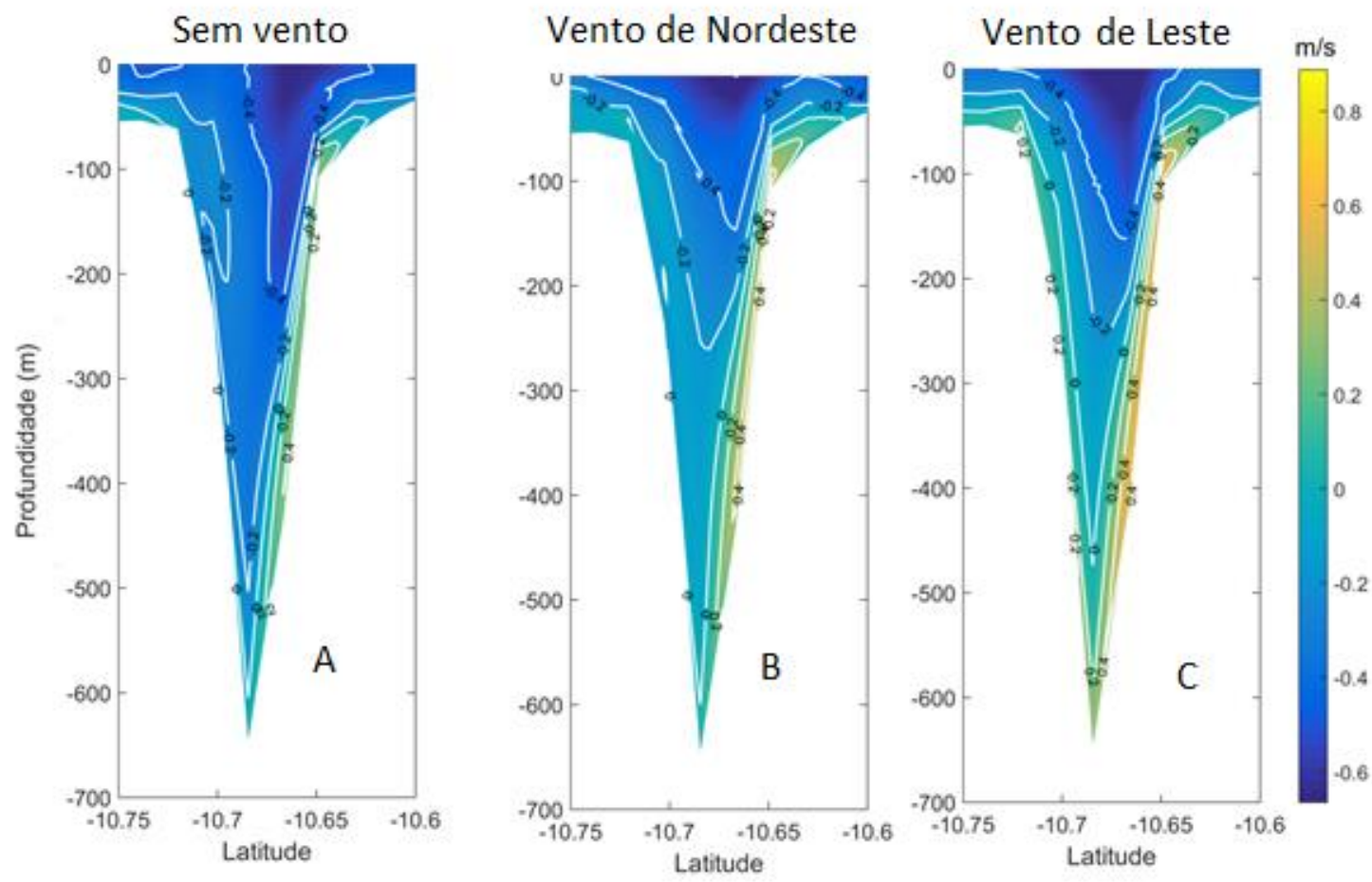

Figura 46 - Correntes na seção do cânion do São Francisco em julho, nos cenários sem vento (A), vento de Nordeste (B) e vento de Leste (C).
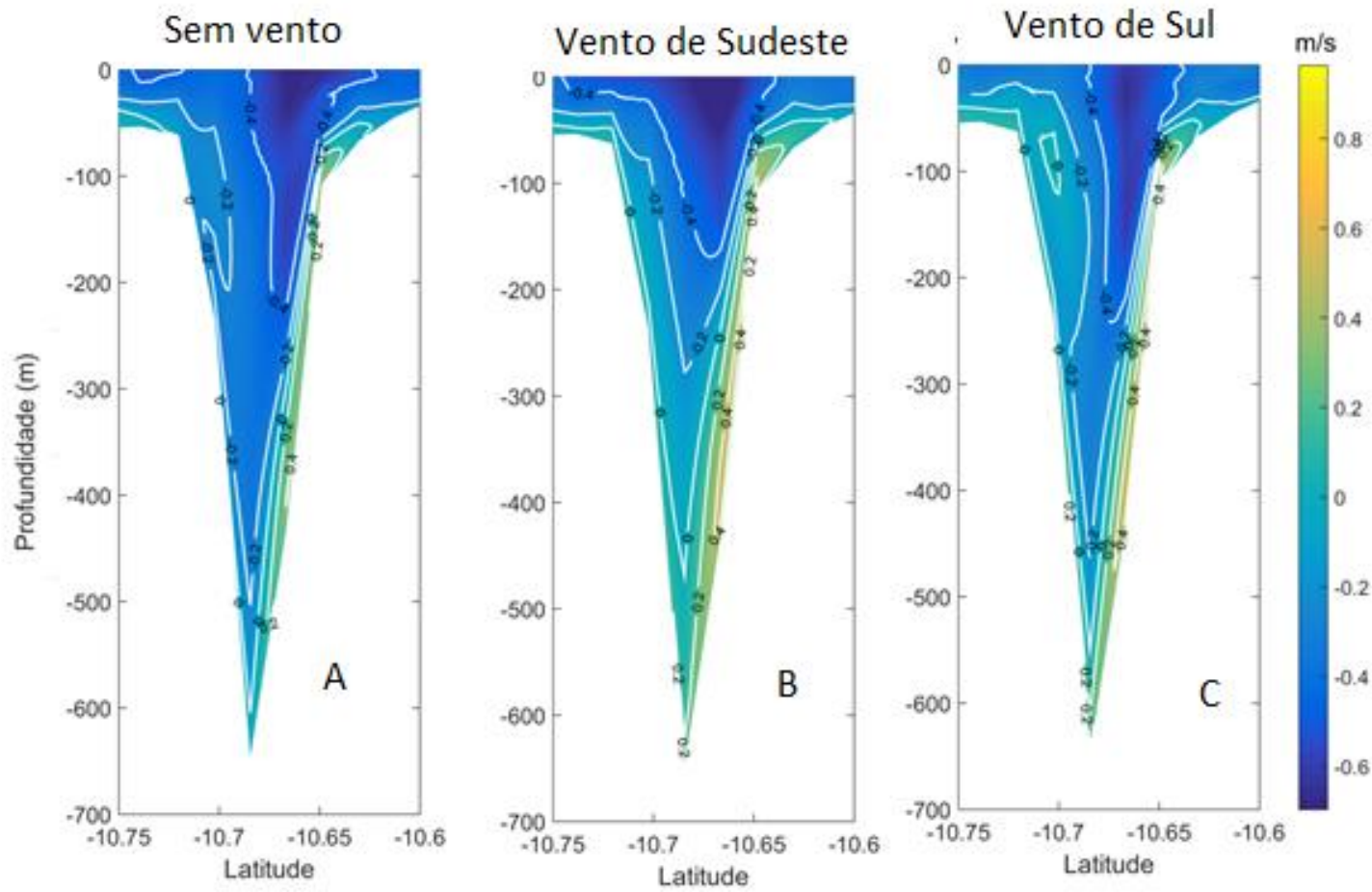

Figura 47 - Correntes nas seção do cânion do São Francisco em julho, nos cenários sem vento $(A)$, vento de Sudeste (B) e vento de Sul (C). 
Para o cânion de Japaratuba (Figura 48 esq.), o transporte é semelhante para os ventos de Nordeste, Leste e Sudeste, sendo menores para ventos de Nordeste. O transporte é positivo para profundidades maiores que $250 \mathrm{~m}$, e maiores que a condição sem vento abaixo de $300 \mathrm{~m}$ de profundidade. Em regiões mais rasas que $200 \mathrm{~m}$ de profundidade, estas condições de vento apresentam transporte negativo, enquanto que a condição sem vento é positiva em regiões mais rasas que $150 \mathrm{~m}$. Para ventos de Sul, o perfil do transporte é bastante distinto das outras condições, sendo positivo e o mais intenso de todos até $150 \mathrm{~m}$ de profundidade, negativo entre 150 e $550 \mathrm{~m}$, e positivo novamente entre 550 e $800 \mathrm{~m}$.

Já para o cânion do São Francisco (Figura 48 dir.), o transporte é praticamente o mesmo para todas as condições de vento, sendo negativo até $350 \mathrm{~m}$ de profundidade, e quase nulo para regiões mais profundas. Para profundidades maiores que $100 \mathrm{~m}$, o transporte mais negativo entre os cenários foi o sem vento, ou seja, é o mais intenso de regiões mais profundas em direção ao cânion.
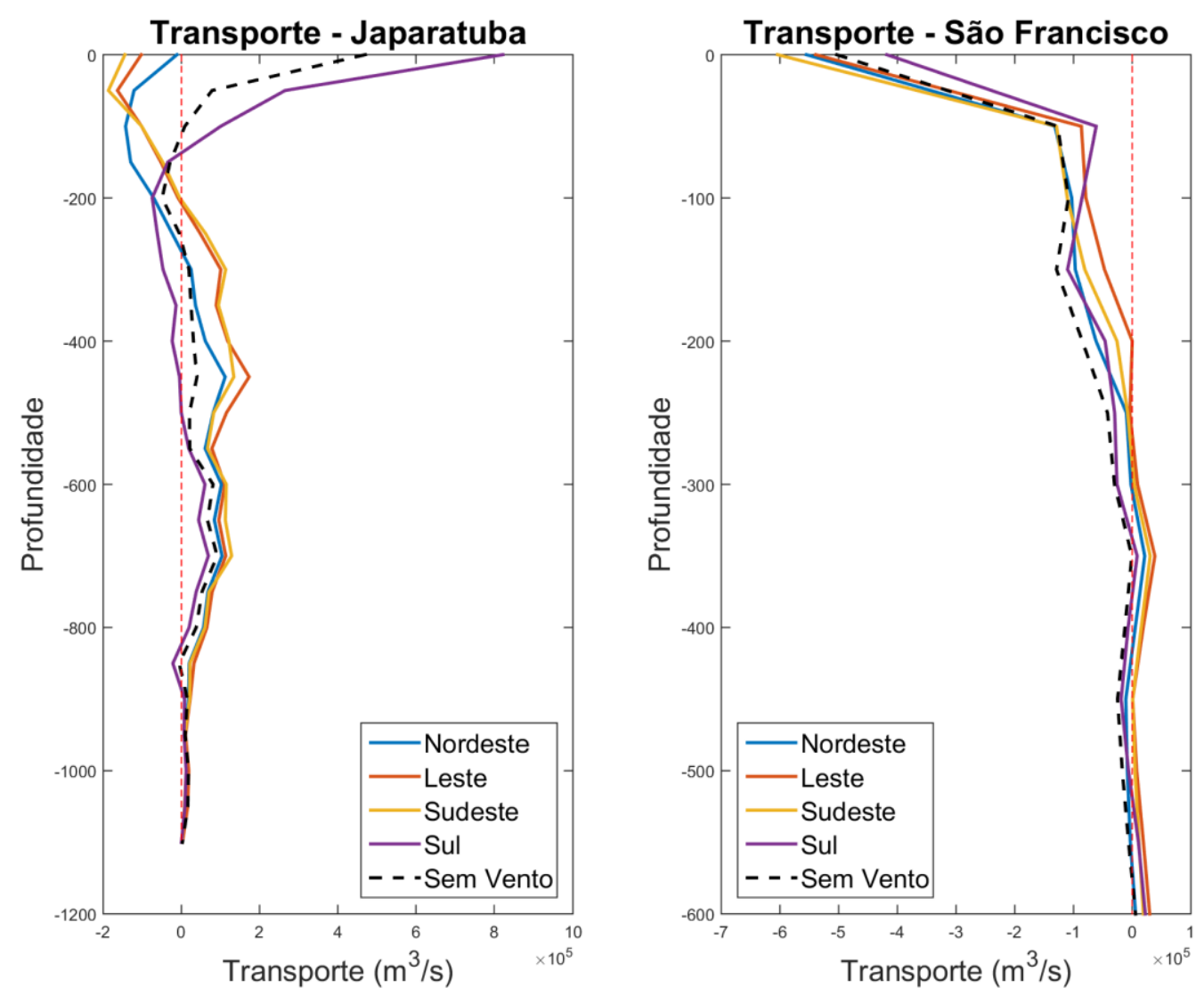

Figura 48 - Transporte em função da profundidade nas seções dos cânions de Japaratuba e São Francisco para o mês de julho para as condições de vento de Nordeste, Leste, Sudeste, Sul e sem vento. 


\subsection{4 - Setembro: Cenários com ventos de Nordeste, Leste, Sudeste e Sul (B)}

Os campos médios mensais de temperatura e salinidade utilizados no mês de setembro para os cânions de Japaratuba e do São Francisco estão apresentados na Figura 49, nas seções da Figura 8.

No cânion de Japaratuba (Figura 49), a salinidade varia de 34,5 até 37, sendo mais salino em regiões mais rasas, enquanto a temperatura cai de $25^{\circ} \mathrm{C}$ a $100 \mathrm{~m}$ de profundidade até 5ํ C no fundo. Já no cânion de Sâo Francisco, a salinidade vai de 34,5 até 37 , também mais salino em regiões mais rasas. Já a temperatura varia de $8^{\circ} \mathrm{C}$ a $25^{\circ} \mathrm{C}$.

A circulação na área de estudo para as profundidades 100, 200, 300 e 400 m, nas condições de ventos constantes (simulações B) para ventos de Nordeste (Figura 50), Leste (Figura 51), Sudeste (Figura 52) e Sul (Figura 53) apresentam-se bastante semelhantes. Em todas as situações, as correntes são predominantemente para Nordeste e Leste, com valores máximos chegando a $1,2 \mathrm{~m} . \mathrm{s}^{-1}$. Os fluxos mais intensos ocorrem afastados da costa.

(a) Salinidade - Japaratuba

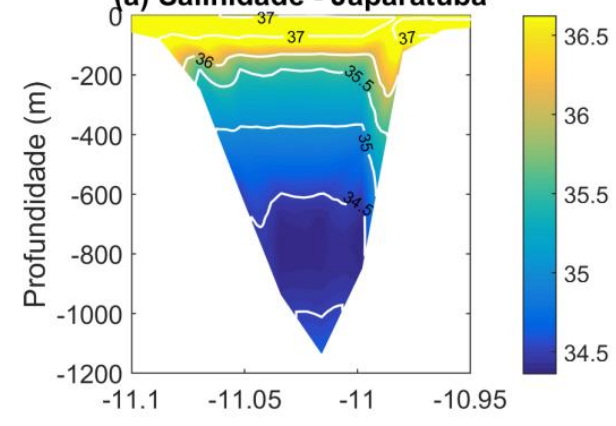

(c) Temperatura - Japaratuba $\left({ }^{\circ} \mathrm{C}\right)$

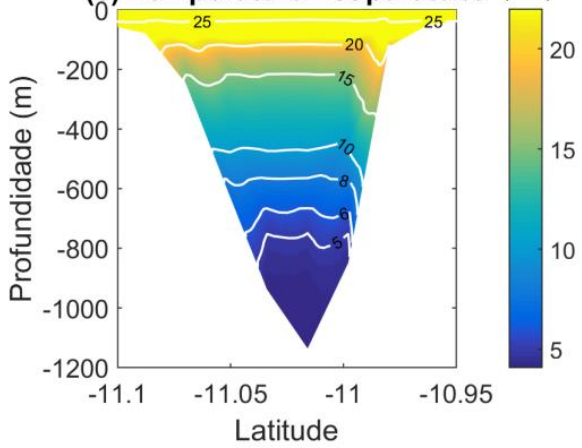

(b) Salinidade - S. Francisco

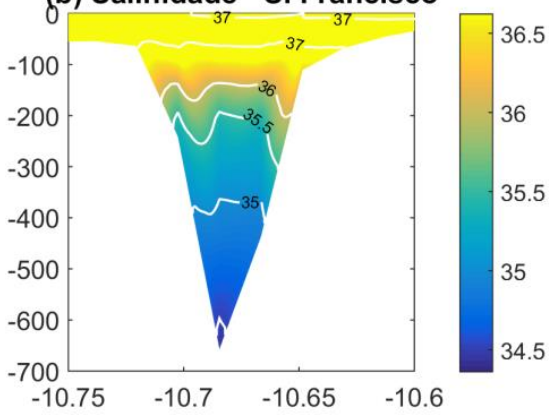

(d) Temperatura - S. Francisco $\left({ }^{\circ} \mathrm{C}\right)$

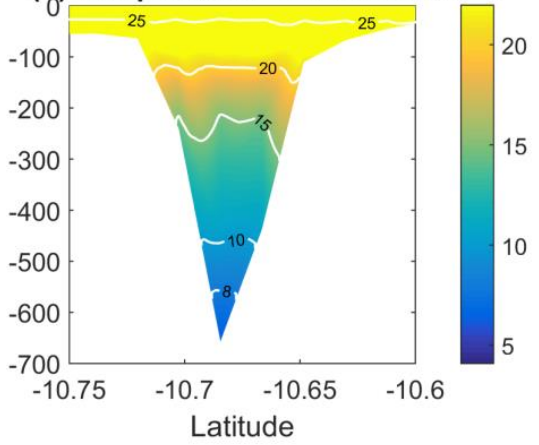

Figura 49 - Salinidade e temperatura nas seções dos cânions de Japaratuba e do São Francisco para o mês de setembro. 

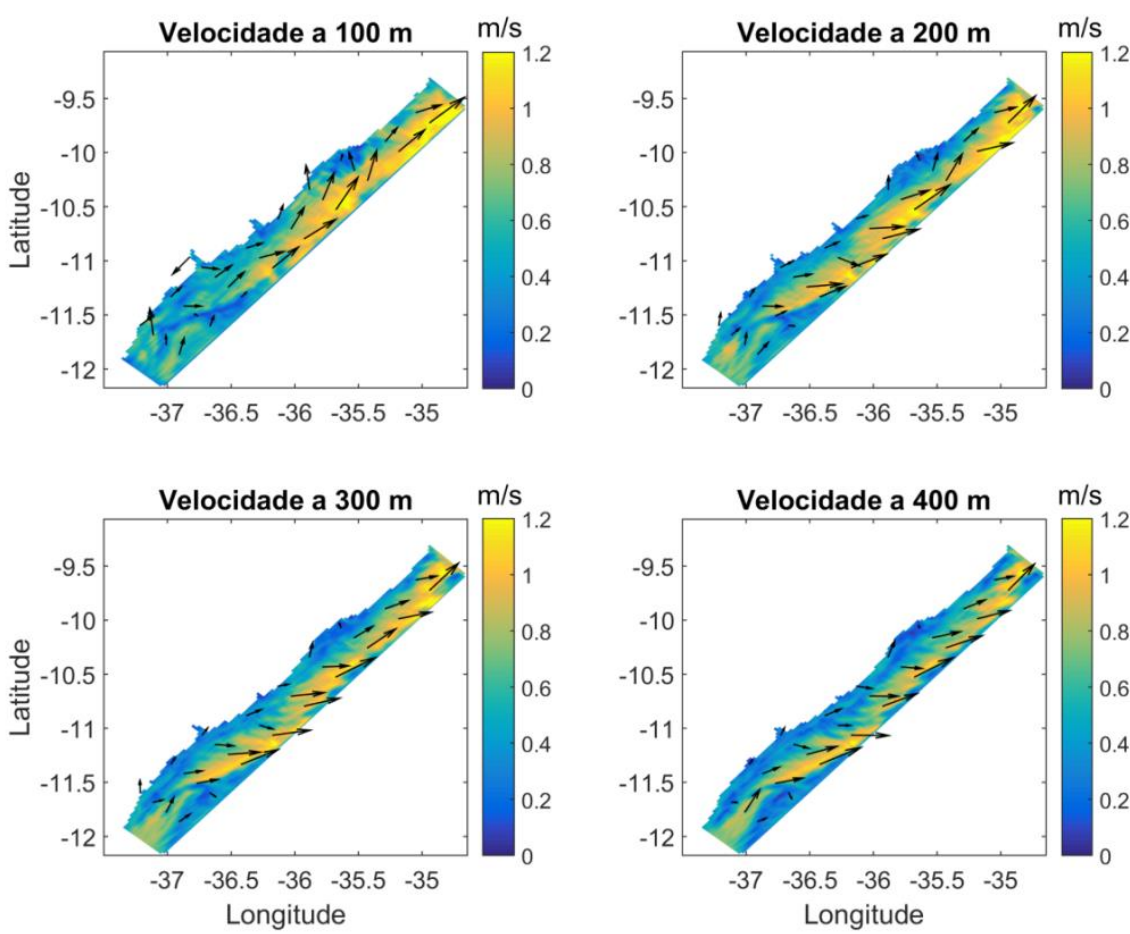

Figura 50 - Circulação na área de estudo para setembro e vento de Nordeste, a 100, 200, 300 e 400 m.
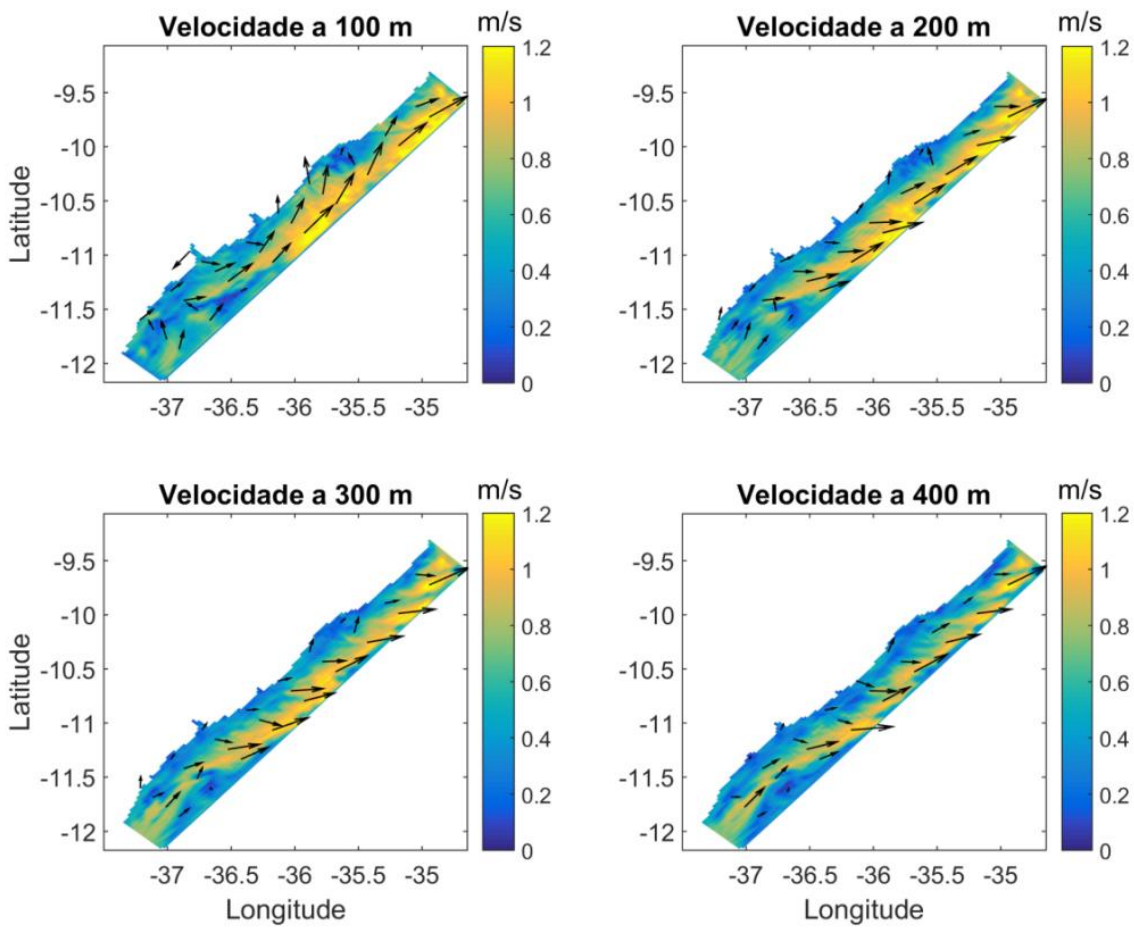

Figura 51 - Circulação na área de estudo para setembro e vento de Leste, a 100, 200, 300 e 400 m. 

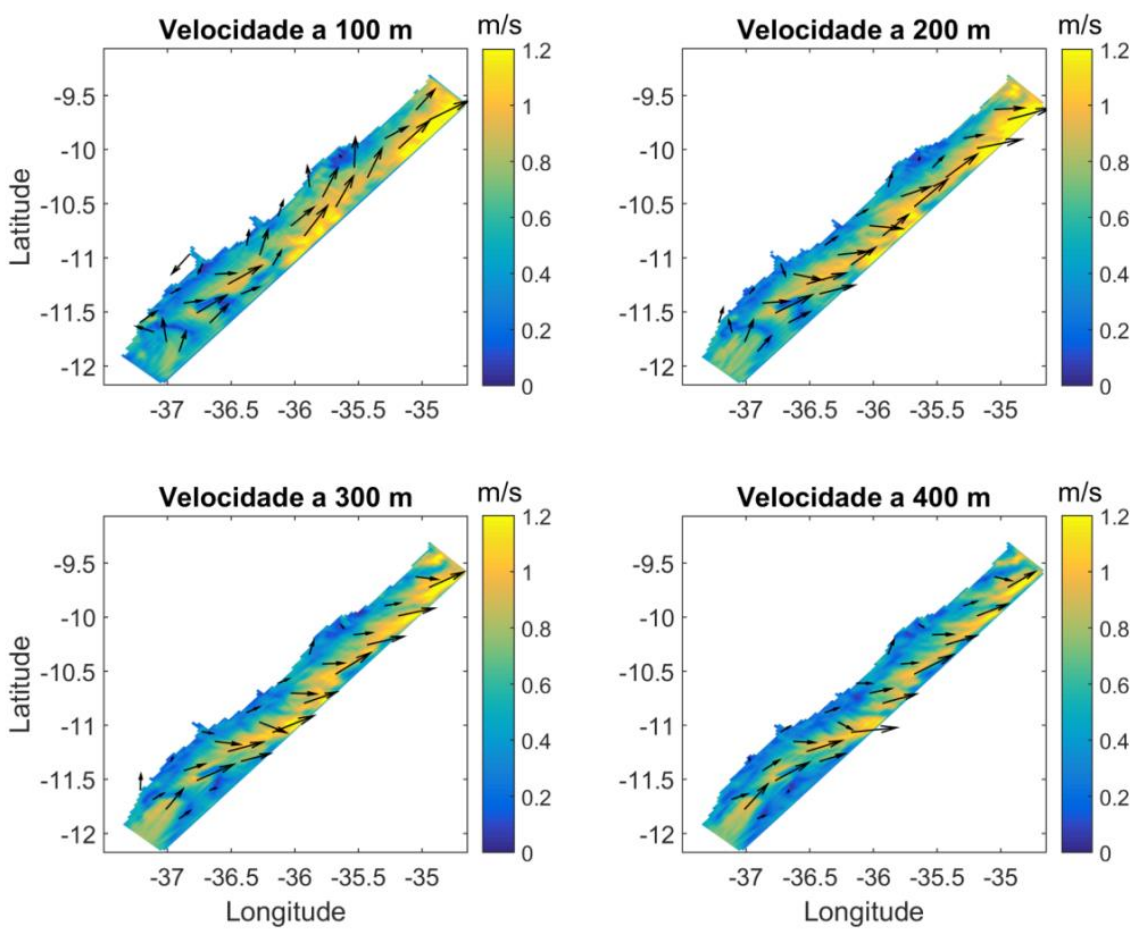

Figura 52 - Circulação na área de estudo para setembro e vento de Sudeste, a 100, 200, 300 e $400 \mathrm{~m}$.
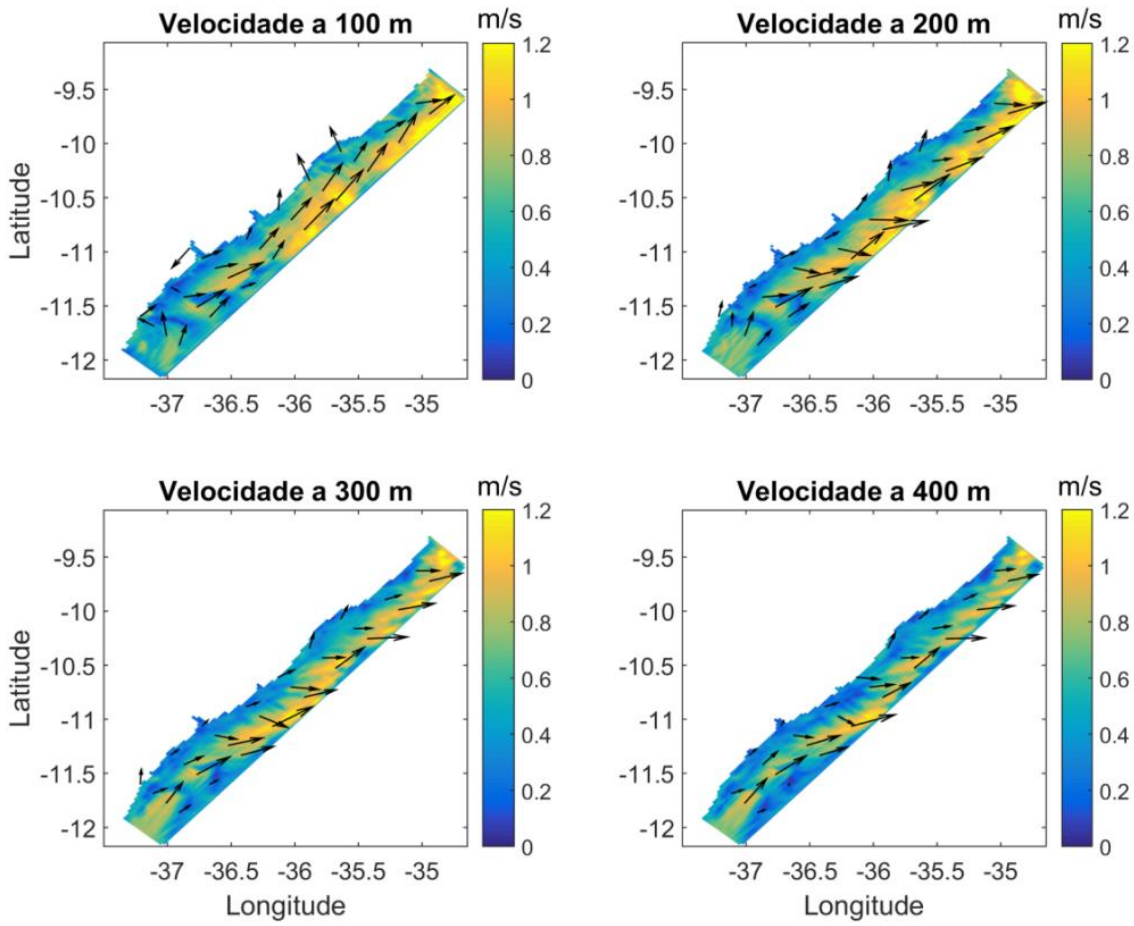

Figura 53 - Circulação na área de estudo para setembro e vento de Sul, a 100, 200, 300 e 400 m. 
Na Figura 54 são apresentadas a energia cinética total, em função do tempo, para o mês de setembro, para as condições sem vento, e de ventos de Nordeste, Leste, Sudeste e Sul. Os comportamentos são semelhantes para todos os cenários, com aumento rápido até aproximadamente 12 dias, e posteriormente mantem seus valores abaixo de um patamar de $3,3 \times 10^{4} \mathrm{~J} / \mathrm{kg}$. Também são semelhantes aos meses de março e julho, o que mostra que o período de 15 dias de aquecimento é suficiente para estabilizar a simulação.

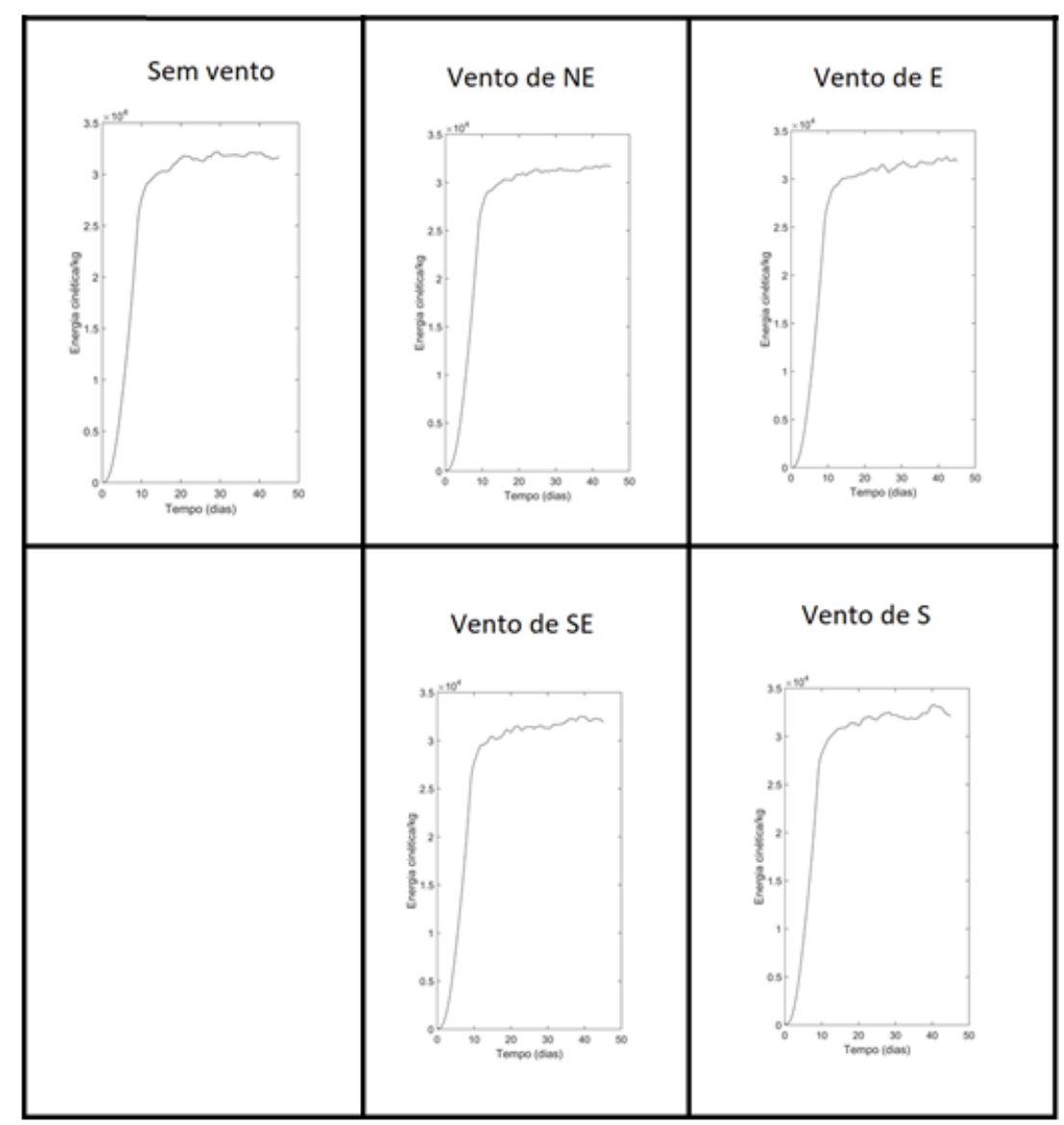

Figura 54 - Energia cinética em função do tempo para o mês de setembro, nas condições sem vento, com ventos de NE, E, SE e $S$. 

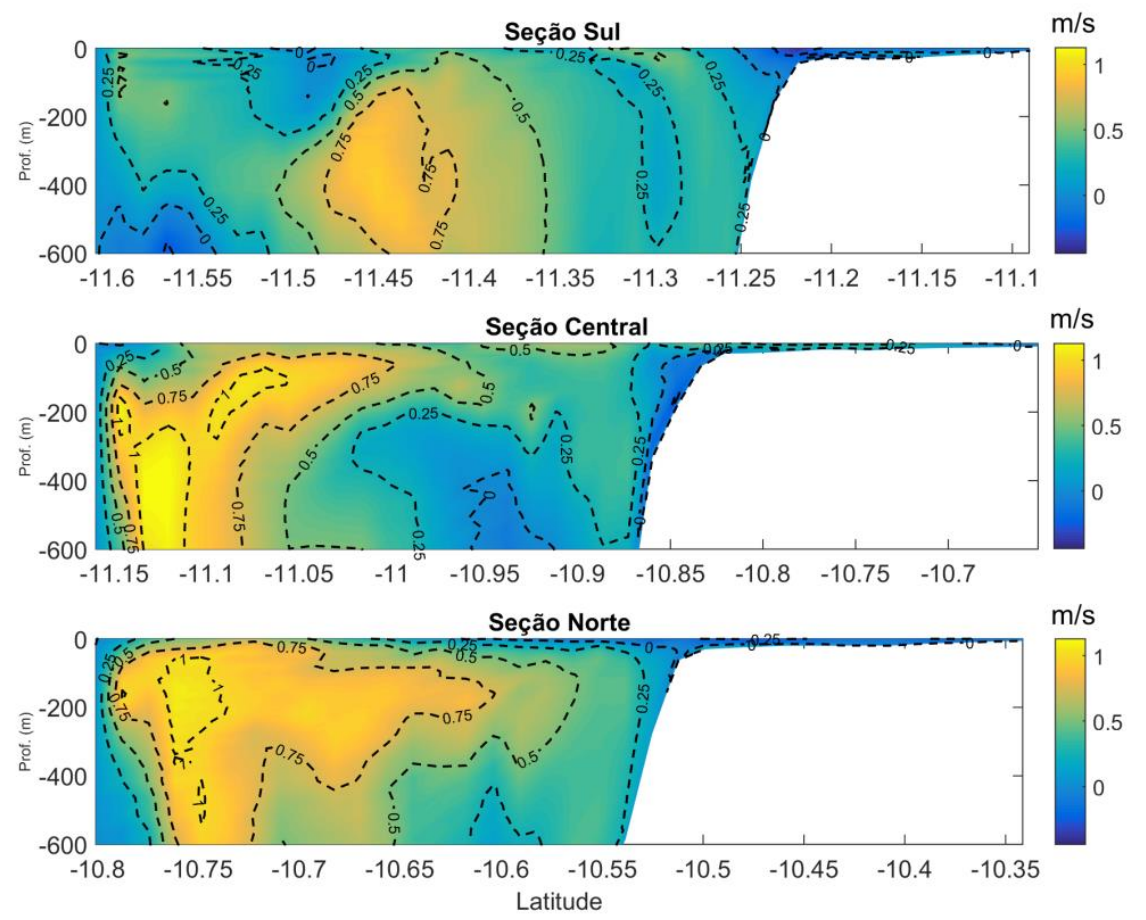

Figura 55 - Corrente no mês de setembro para ventos de Nordeste, nas seções Sul, Central e Norte.
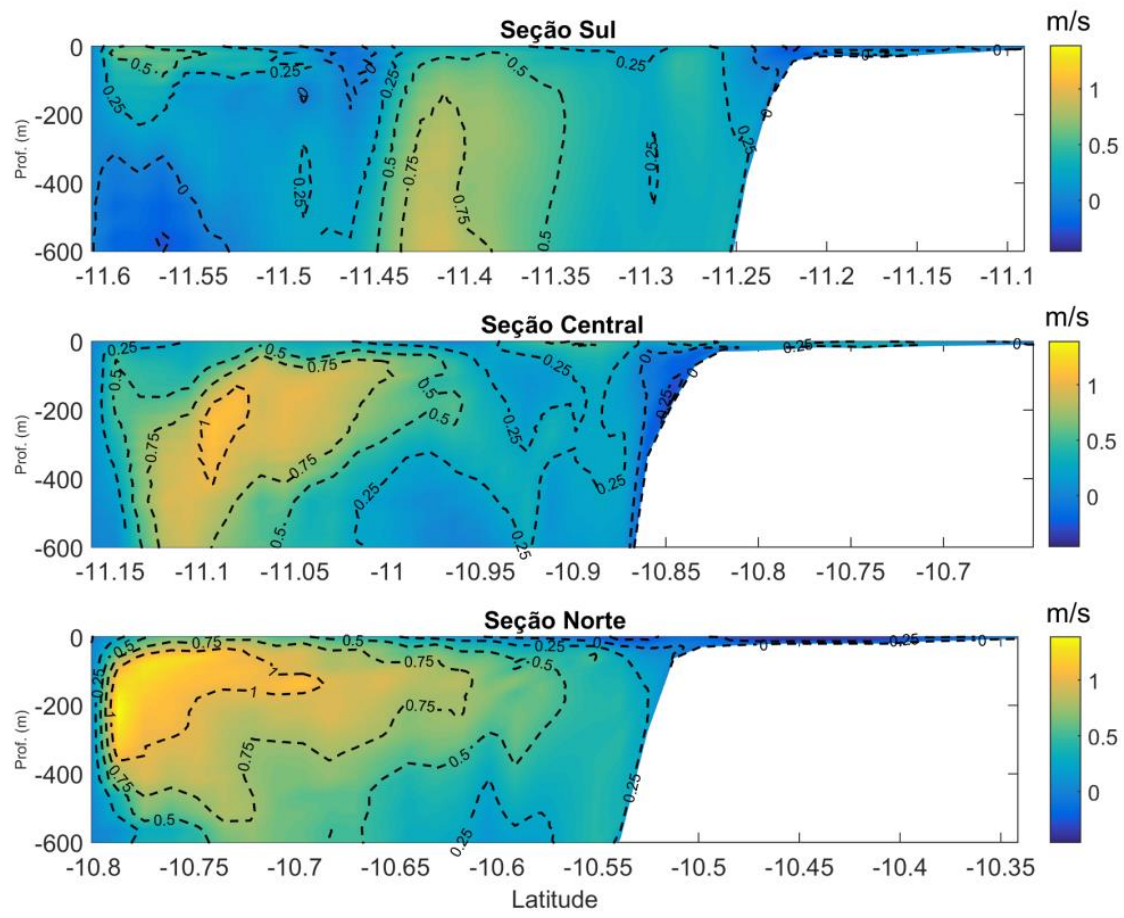

Figura 56 - Corrente no mês de setembro para ventos de Leste, nas seções Sul, Central e Norte. 

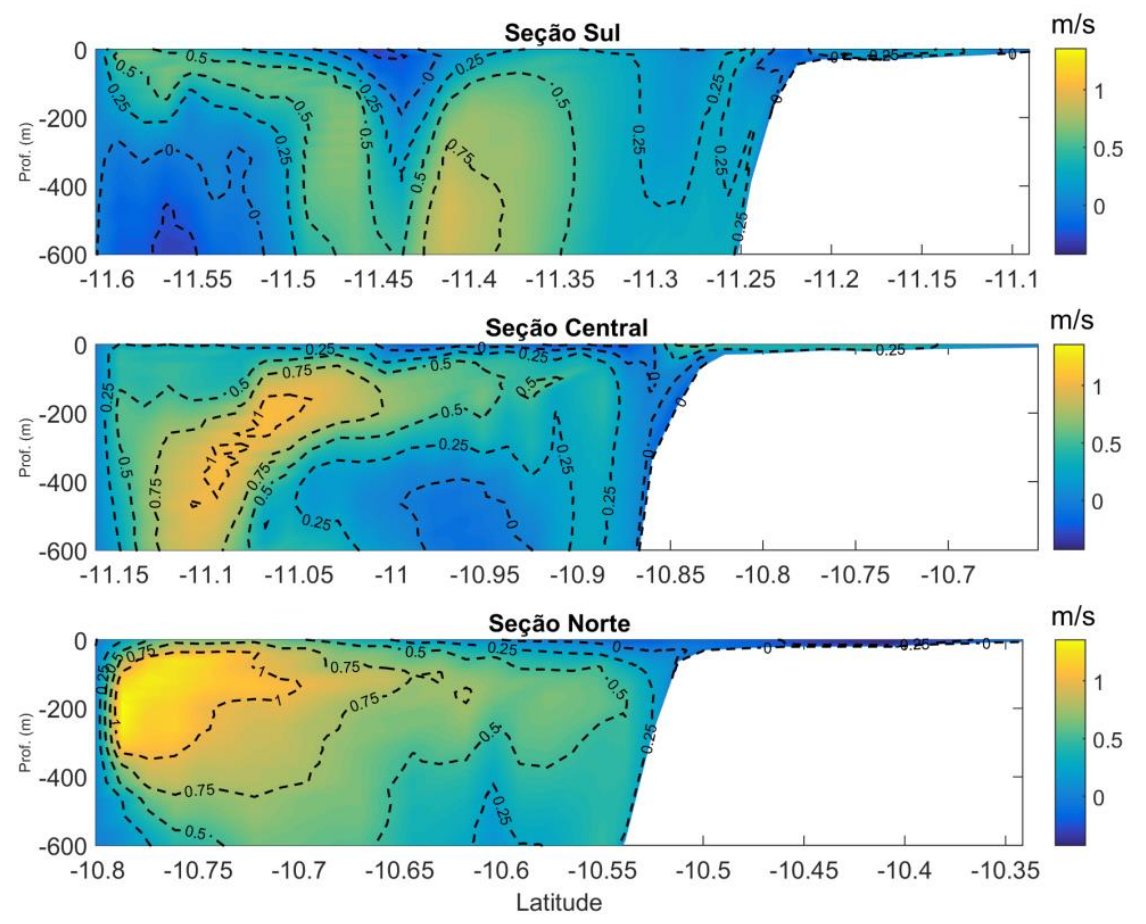

Figura 57 - Corrente no mês de setembro para ventos de Sudeste, nas seções Sul, Central e Norte.
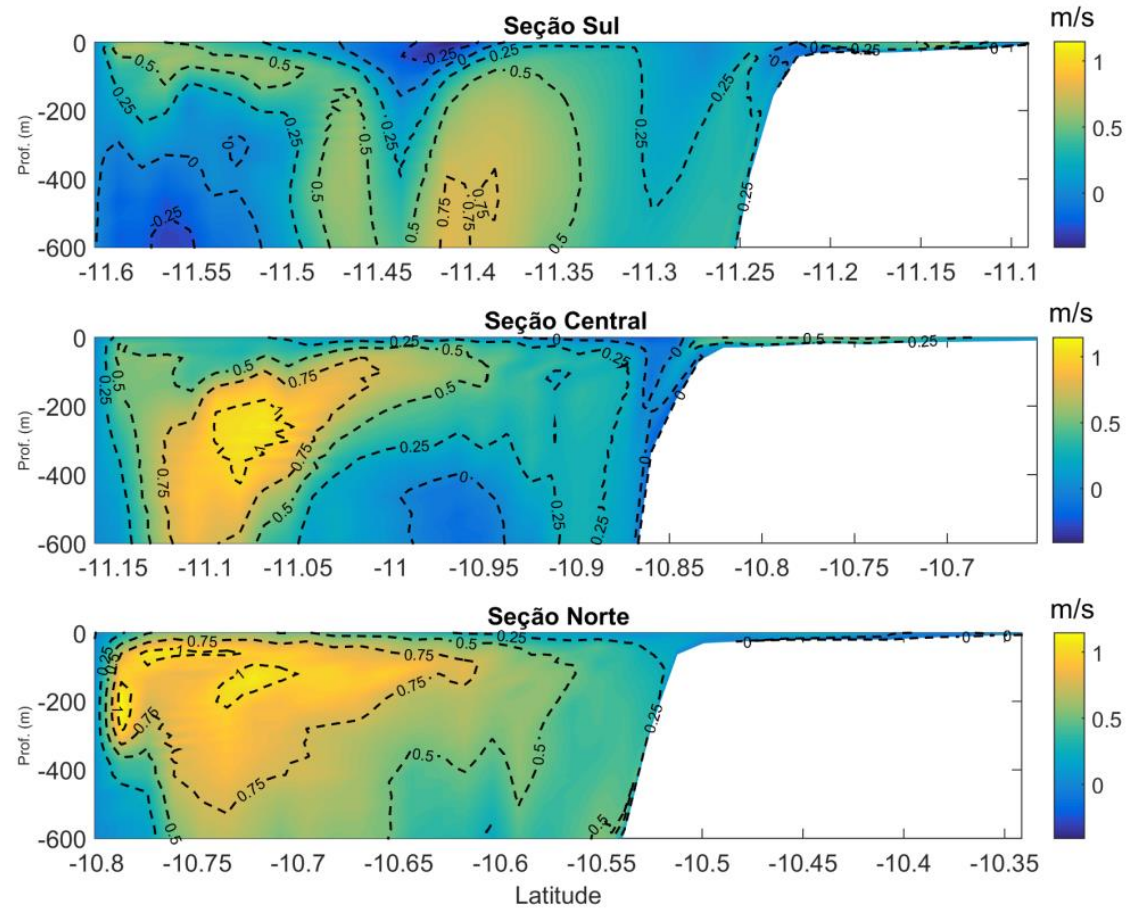

Figura 58 - Corrente no mês de setembro para ventos de Sul, nas seções Sul, Central e Norte. 
As velocidades nas seções perpendiculares à costa (Figura 8) para as condições sem vento (Figura 14 inf.), ventos de Nordeste (Figura 55), de Leste (Figura 56), de Sudeste (Figura 57) e de Sul (Figura 58), para o mês de setembro, apresentam predomínio de correntes positivas para Nordeste, mas há também fluxos negativos para Sudoeste na região de PC. Também pode ser observado que o núcleo da SNB ocorre em subsuperfície, entre 100 e 300 m, com valores máximos entre 0,8 e 1,2 m.s ${ }^{-1}$. Quando adicionamos vento como forçante (B), e compararmos as condições sem vento (A) (Figura 14), são observadas algumas alterações.

Ao adicionar vento de Nordeste (Figura 55) e de Leste (Figura 56), podemos observar uma intensificação das correntes positivas em torno do núcleo da SNB, porém, é observado também diminuição das correntes próximas à costa nas seções Sul e Central, e na seção Norte observa-se que as correntes negativas que ficam restritas à PC no cenário sem vento, se intensificam e atingem entre 50 e $100 \mathrm{~m}$ de profundidade ao adicionar essas condições de vento. O núcleo da SNB apresentouse entre 200 e 400 m de profundidade dependendo da seção e condição de vento.

Quando foi adicionado vento de Sudeste (Figura 57) e de Sul (Figura 58), houve uma intensificação das correntes positivas próximo ao núcleo da SNB, e atenuação próximo à costa, nas seções Central e Sul. Porém, na seção Norte, houve intensificação das correntes, com o núcleo em subsuperfície a 200 m de profundidade. Também observa-se na seção Norte, que as correntes negativas continuam restritas à PC, tanto no cenário sem vento quanto para ventos de Sudeste e Sul.

As correntes na seção do cânion de Japaratuba para as condições sem vento (Figura 59A), ventos de Nordeste (Figura 59B), de Leste (Figura 59C), de Sudeste (Figura 60B) e de Sul (Figura 59C) são predominantemente positivas (da costa em direção a regiões mais profundas), excetuando até $300 \mathrm{~m}$ de profundidade, na parte central do cânion, onde ocorrem fluxos negativos, variando de - 0,80 a 0,80 m.s ${ }^{-1}$, sendo que os valores mais negativos ocorrem perto da superfície, e os mais positivos ocorrem nas bordas do cânion. Já no cânion do São Francisco (Figura 61 e Figura 62) ocorre o inverso, sendo as correntes predominantemente negativas, excetuando a região da borda norte abaixo de $50 \mathrm{~m}$ de profundidade, com valores variando de $-0,5$ a $0,2 \mathrm{~m} . \mathrm{s}^{-1}$, com os valores mais negativos na região central do 
cânion entre 100 e $350 \mathrm{~m}$ de profundidade, e os valores máximos na ocorrem na borda norte do cânion.

Ao adicionarmos vento de Nordeste (Figura 59B), de Leste (Figura 59C) ou de Sudeste (Figura 59B), ocorre intensificação das correntes no cânion de Japaratuba, sendo que até $250 \mathrm{~m}$ de profundidade as correntes ficam mais negativas, enquanto que abaixo dessa profundidade elas ficam mais positivas, ou seja, há intensificação das correntes. A intensificação mais evidente das correntes negativas se dá na região central do cânion, até $300 \mathrm{~m}$ de profundidade, onde a área com velocidades negativas aumenta de tamanho, e também abaixo de $200 \mathrm{~m}$ na borda Sul, mais evidente para ventos de Sudeste, onde a atenuação é maior.

Ao adicionarmos vento de Sul (Figura 60C), apresentou-se um perfil diferente das outras condições de vento. A área onde ocorrem correntes positivas na região superficial próximo à borda Sul do cânion de Japaratuba aumentou de tamanho e passou a ocupar a área onde havia um núcleo de corrente negativa no centro do cânion no cenário sem vento, fazendo com que este núcleo negativo afunde. Isso intensificou as correntes positivas nas regiões mais superficiais até $100 \mathrm{~m}$ de profundidade, e diminuiu as correntes abaixo de $150 \mathrm{~m}$.

Já no cânion do São Francisco as correntes ficaram mais negativas com a adição de vento de Nordeste (Figura 61), Leste (Figura 61C) e Sudeste (Figura 62B), ou seja, aumentou o fluxo de regiões mais profundas em direção ao cânion. Isto ocorreu principalmente nos primeiros $100 \mathrm{~m}$ de profundidade, onde aumentou a área de correntes negativas na região central do cânion, e diminuiu a área de correntes positivas na borda Norte do cânion, sendo mais evidente para ventos de Leste. Para a adição de ventos de Sul (Figura $62 \mathrm{C}$ ), houve diminuição de correntes positivas nos primeiros $100 \mathrm{~m}$ de profundidade, ou seja, aumentou o fluxo vindo de regiões mais profundas em direção ao cânion. Porém, abaixo de $100 \mathrm{~m}$, onde o fluxo é predominantemente negativo, houve atenuação das correntes, ou seja, diminuiu 0 fluxo de regiões mais profundas em direção ao cânion. 

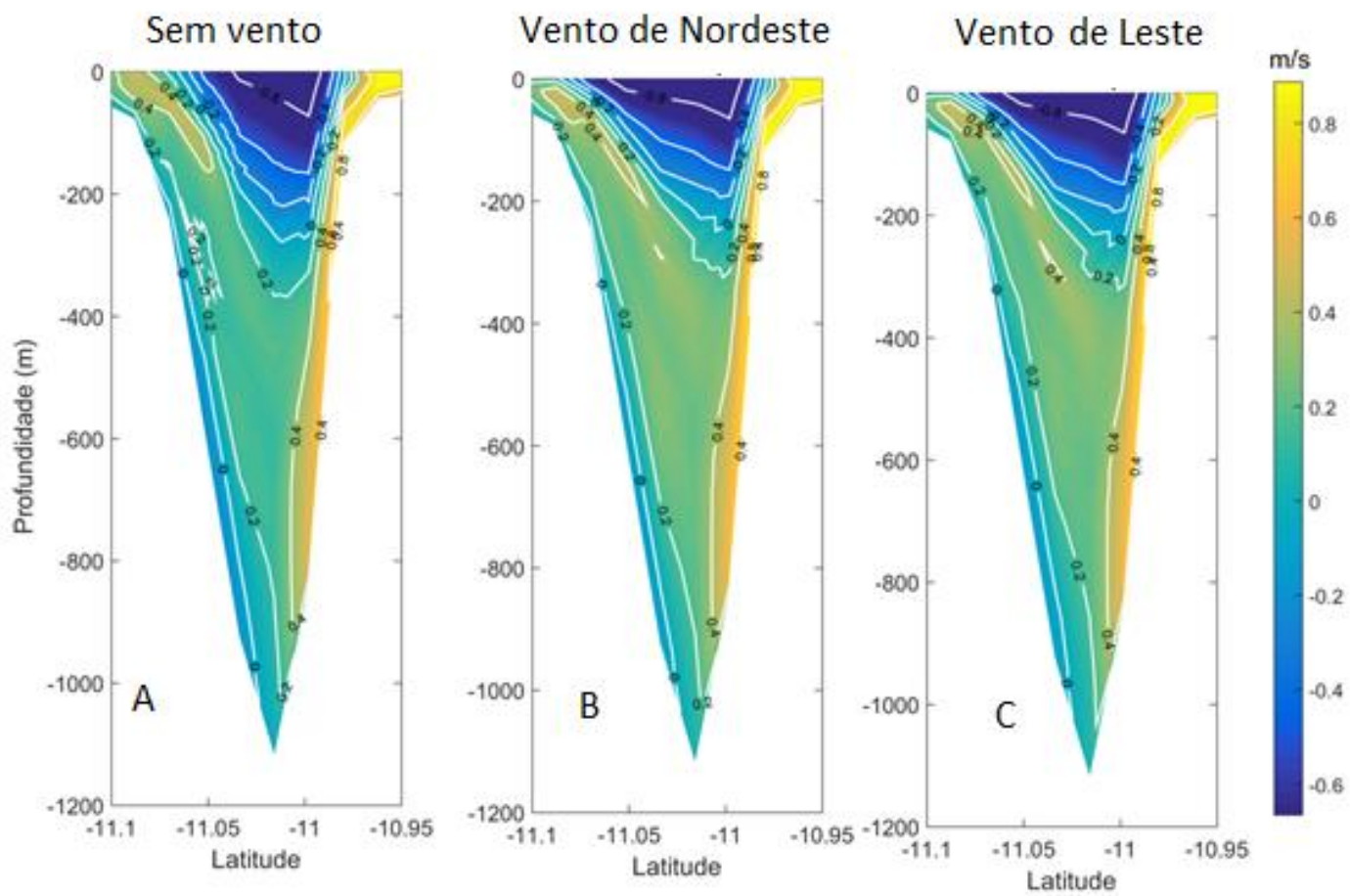

Figura 59 - Correntes nas seções do cânion de Japaratuba em setembro, nos cenários sem vento $(A)$, vento de Nordeste $(B)$ e vento de Leste $(C)$.
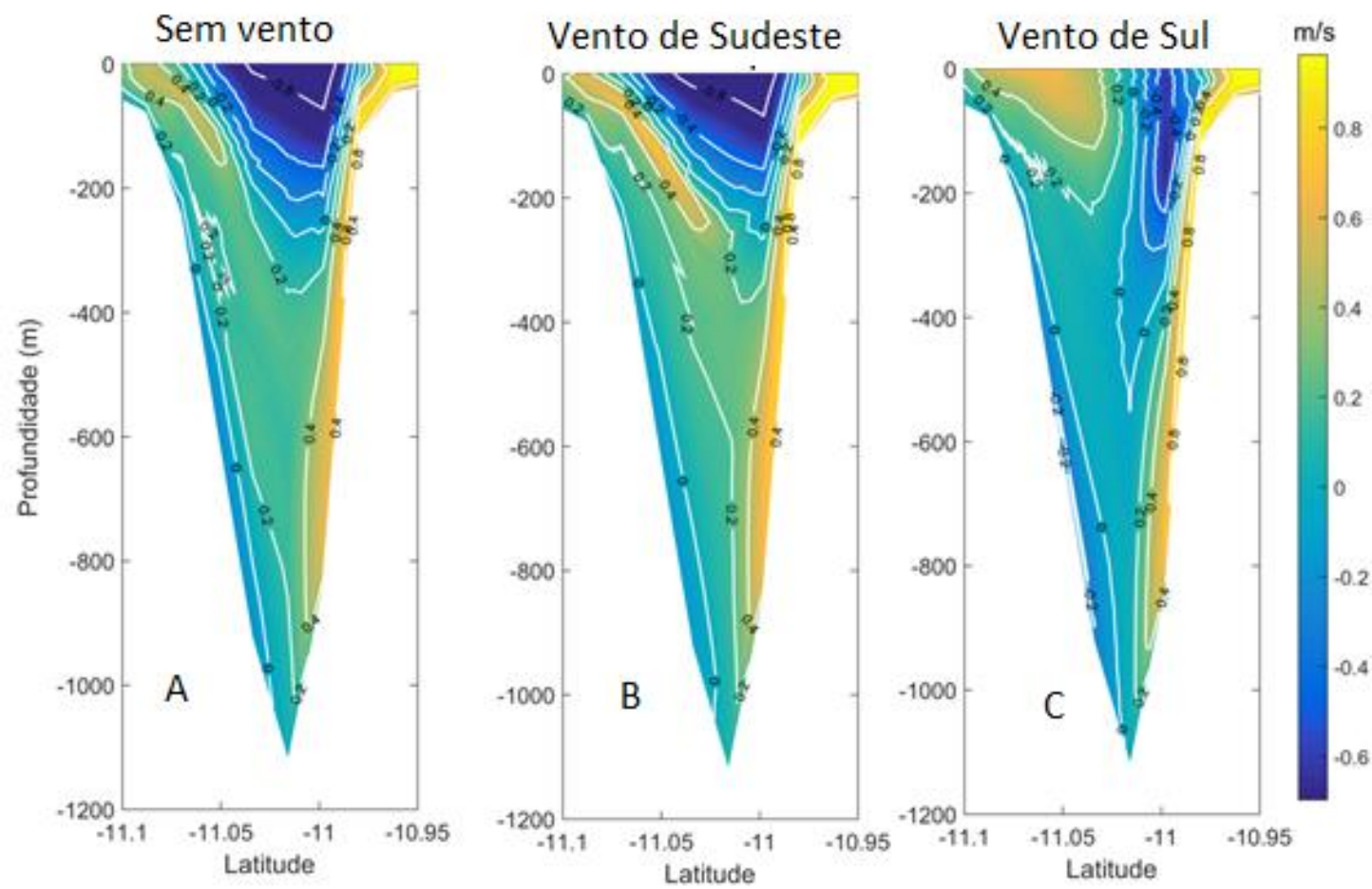

Figura 60 - Correntes nas seções do cânion de Japaratuba em setembro,nos cenários sem vento $(A)$, vento de Sudeste (B) e vento de Sul (C). 

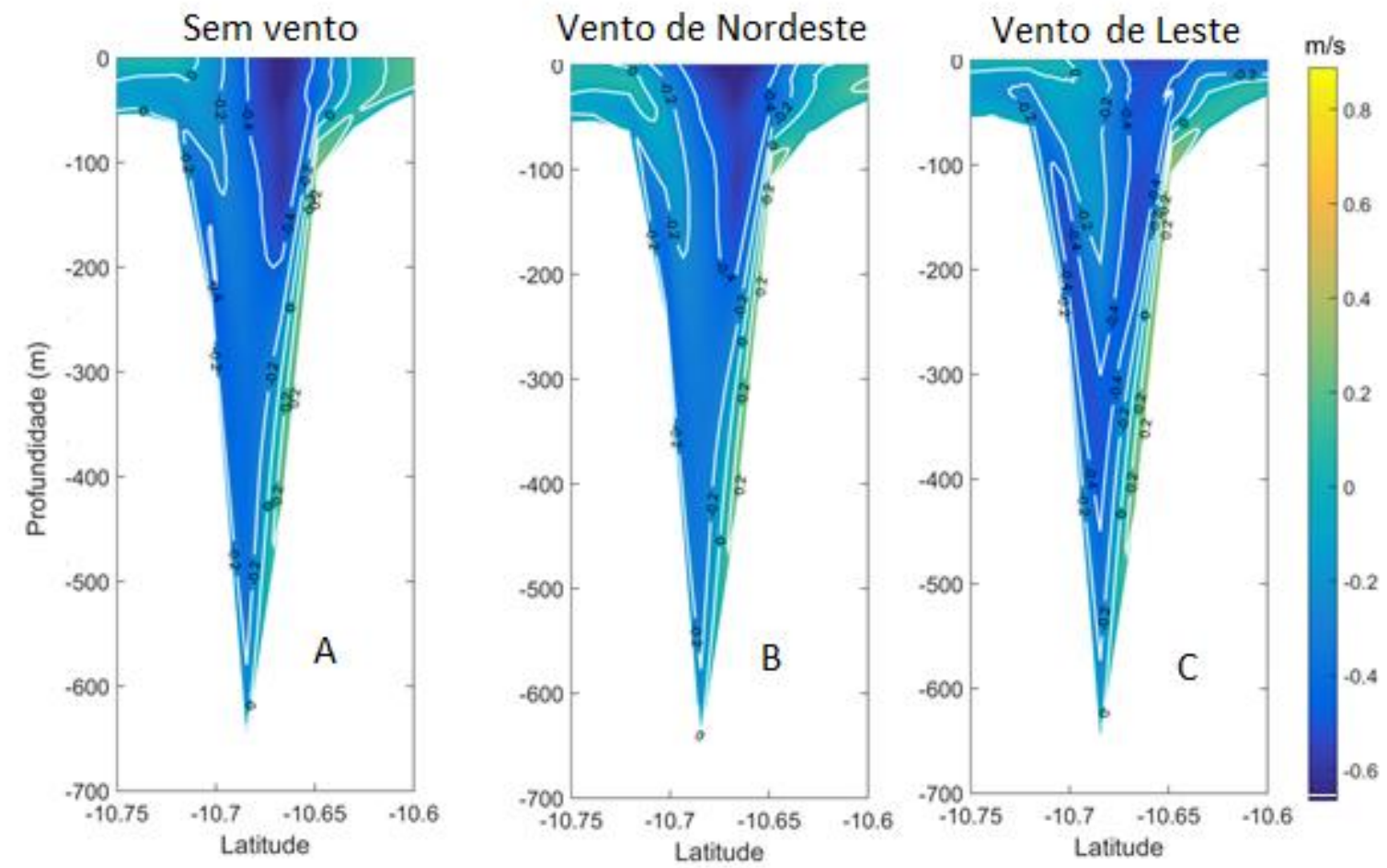

Figura 61 - Correntes nas seções do cânion do São Francisco em setembro, nos cenários sem vento (A), vento de Nordeste (B) e vento de Leste (C).
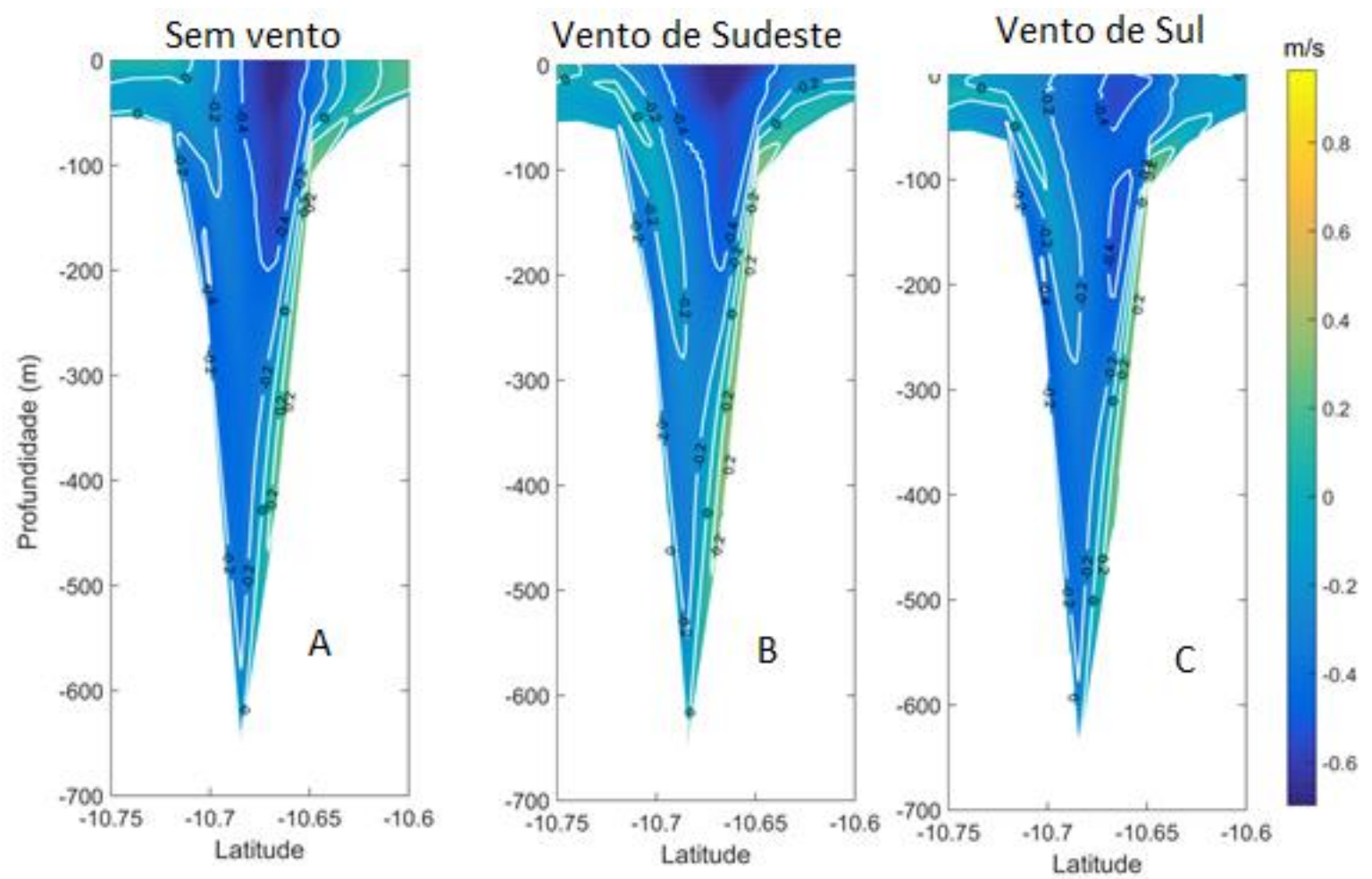

Figura 62 - Correntes nas seções do cânion do São Francisco em setembro, nos cenários sem vento $(A)$, vento de Sudeste (B) e vento de Sul (C). 
Para o cânion de Japaratuba (Figura 63 esq.), o transporte é praticamente o mesmo para os ventos de Nordeste, Leste e de Sudeste, sendo positivo para todas as profundidades maiores que $50 \mathrm{~m}$. Dentre estas três condição de ventos, os de Sudeste apresentam transporte positivo até $150 \mathrm{~m}$ de profundidade, enquanto as outras duas condições apresentam transporte negativo. Para profundidades maiores, a situação se inverte, com as 3 condições de vento gerando transporte positivo, com a condição de ventos de Sudeste apresentando menor transporte entre as 3. Para ventos de Sul, o perfil do transporte é bastante distinto das outras condições, sendo positivo em todas profundidades, e o mais intenso de todos até $150 \mathrm{~m}$ de profundidade, diminuindo com a profundidade até $200 \mathrm{~m}$, e passando a ser o menor de todos para regiões mais profundas que $200 \mathrm{~m}$.
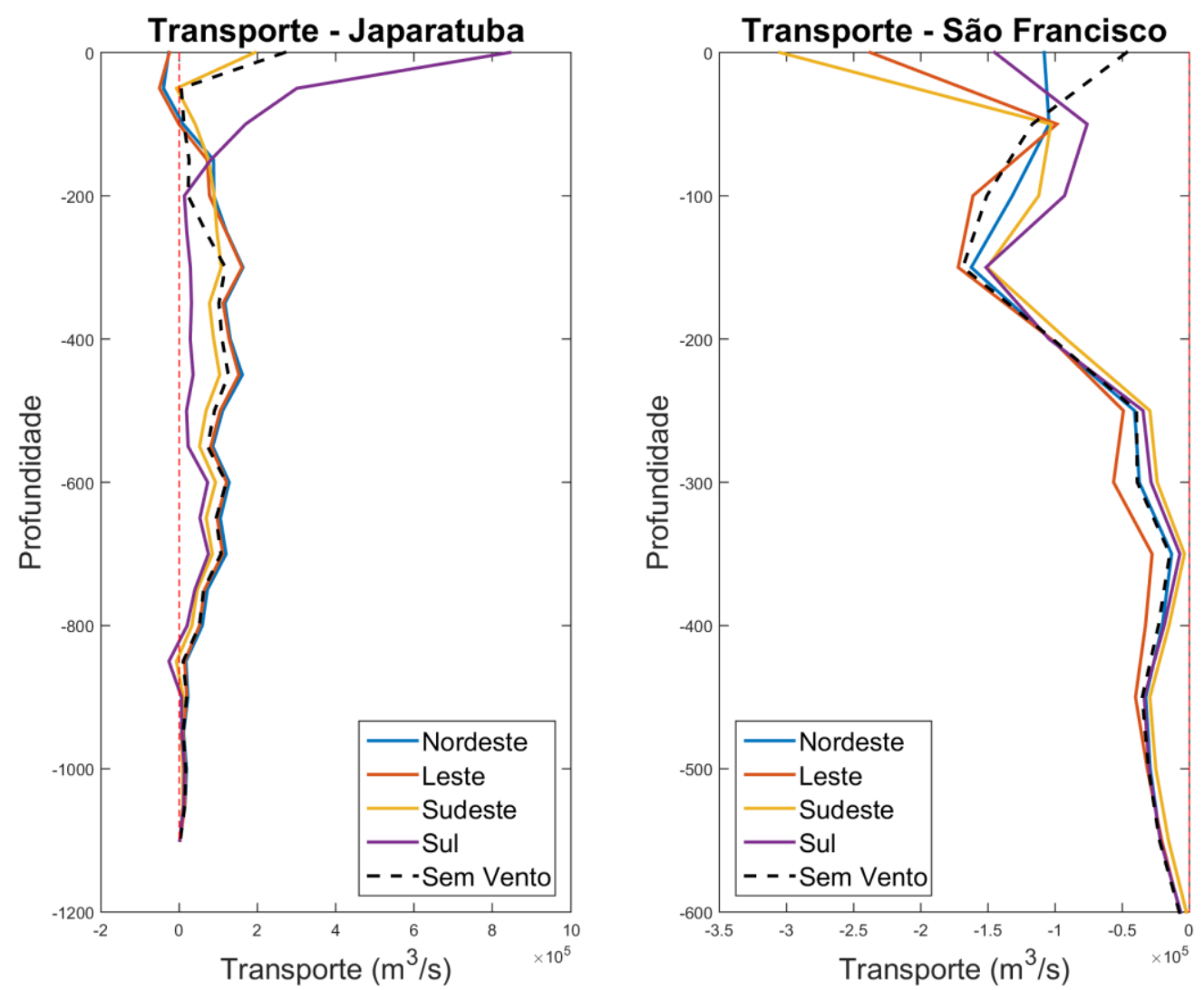

Figura 63 - Transporte em função da profundidade nas seções dos cânions de Japaratuba e São Francisco para o mês de setembro para as condições de vento de Nordeste, Leste, Sudeste, Sul e sem vento. 
Já para o cânion do São Francisco (Figura 63 dir.), o transporte é praticamente o mesmo para todas as condições de ventos para profundidades maiores que $50 \mathrm{~m}$, e negativo para todas as profundidades. $O$ transporte mais negativo se dá para ventos de Leste, seguido pela condição sem ventos, ventos de Nordeste, Sudeste e Sul. Os valores mais negativos abaixo de $50 \mathrm{~m}$, em todas condições de vento, se dá entre 100 e 200 m.

\section{2 - Forçantes: Campo de Te S e Aporte fluvial (C e D), sem vento}

\subsection{1 - Março}

Nesta seção são apresentados os resultados das simulações com campo de $T$ e $S$ referentes aos meses de março, julho e setembro, nas condições com e sem aporte fluvial, em ambos os casos sem a ação do vento. Todos os resultados são referentes ao instante final das simulações. Por inserir água com salinidade diferente dos outros pontos da grade para simular a ação do aporte fluvial, foi necessário simular no modo prognóstico, ou seja, com temperatura e salinidade variando com o tempo. Todas as figuras apresentadas são referentes ao tempo final da simulação, ou seja, após os 15 dias de aquecimento, além dos 30 dias de simulação referente a cada um dos meses.

No cânion de Japaratuba (Figura 64), para a condição com aporte fluvial, a salinidade varia de 35 até 35,5 sendo mais salino em regiões mais rasas, enquanto a temperatura cai de $15^{\circ} \mathrm{C}$ em $100 \mathrm{~m}$ de profundidade até $5^{\circ} \mathrm{C}$ no fundo. Já no cânion de Sâo Francisco, a salinidade vai de 35,1 até 35,5 também mais salino em regiões mais rasas, e a temperatura varia de $7^{\circ} \mathrm{C}$ até $15^{\circ} \mathrm{C}$. Os perfis de temperatura e salinidade para a condição sem aporte fluvial e sem vento (Figura 65) são praticamente idênticos aos perfis considerando aporte fluvial. 

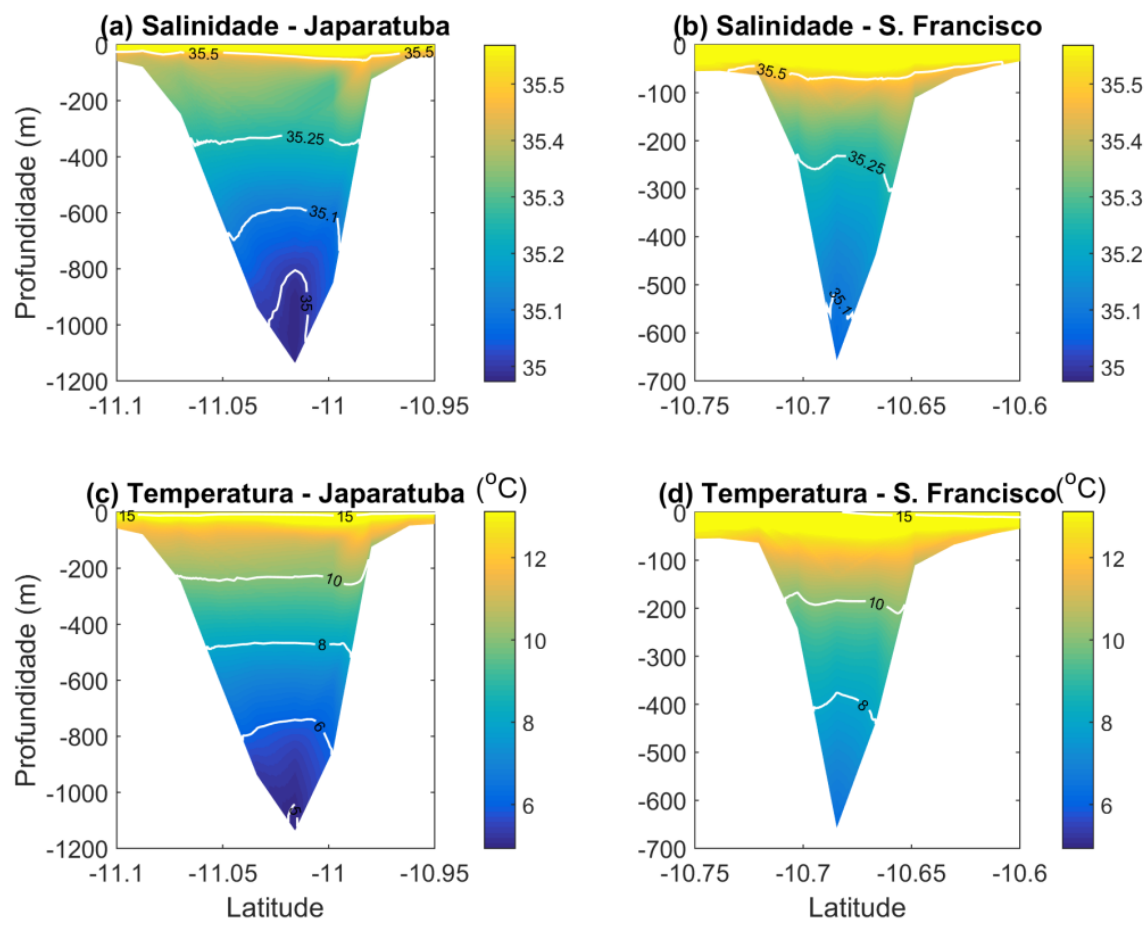

Figura 64 - Salinidade e temperatura nas seções dos cânions de Japaratuba e do São Francisco para o mês de março com aporte fluvial e sem vento.
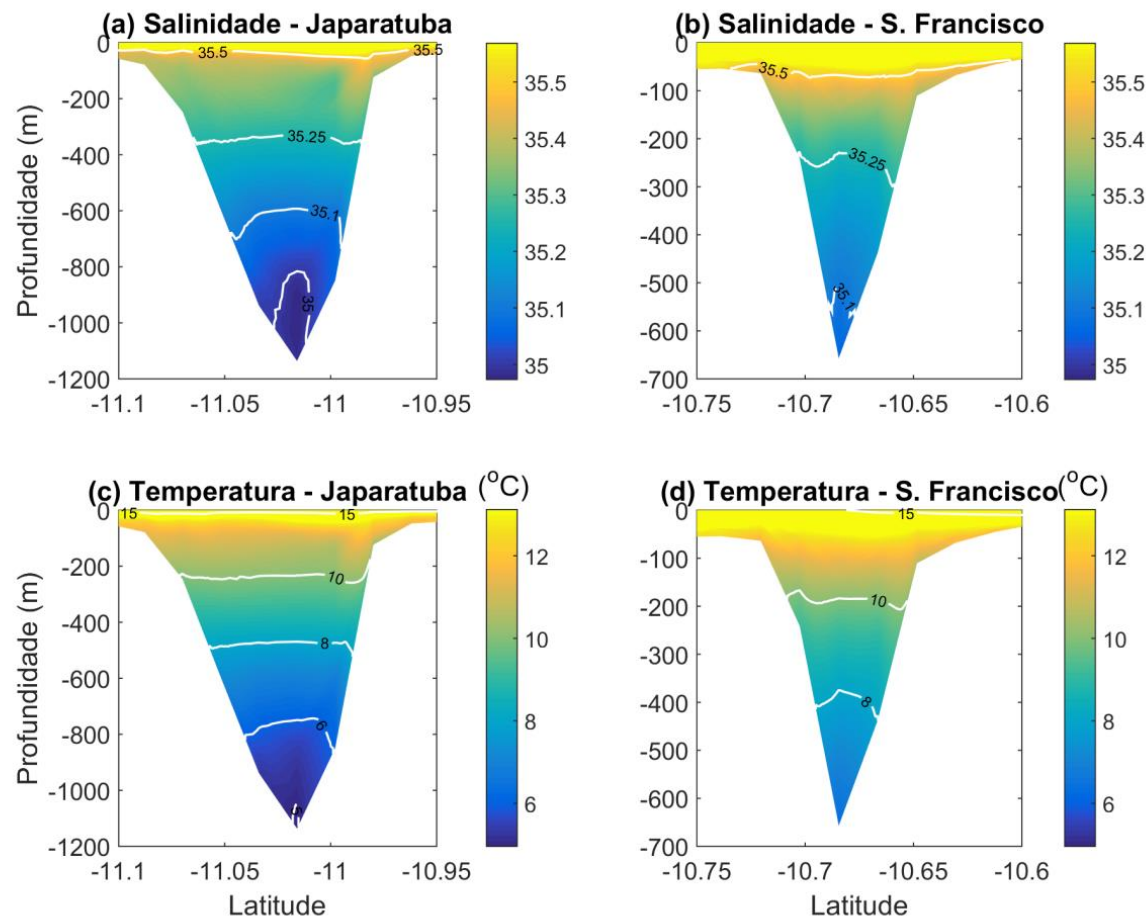

Figura 65 - Salinidade e temperatura nas seções dos cânions de Japaratuba e do São Francisco para o mês de março sem aporte fluvial e sem vento. 
Os comportamentos da energia cinética total em função do tempo, para o mês de março, nas condições com aporte fluvial e sem aporte fluvial (Figura 66), ambos sem a ação de vento, são praticamente idênticos. Ocorre um aumento rápido até aproximadamente 15 dias, seguido por uma redução, e depois os valores se mantém abaixo de um patamar de $4,8 \times 10^{4} \mathrm{~J} / \mathrm{kg}$.

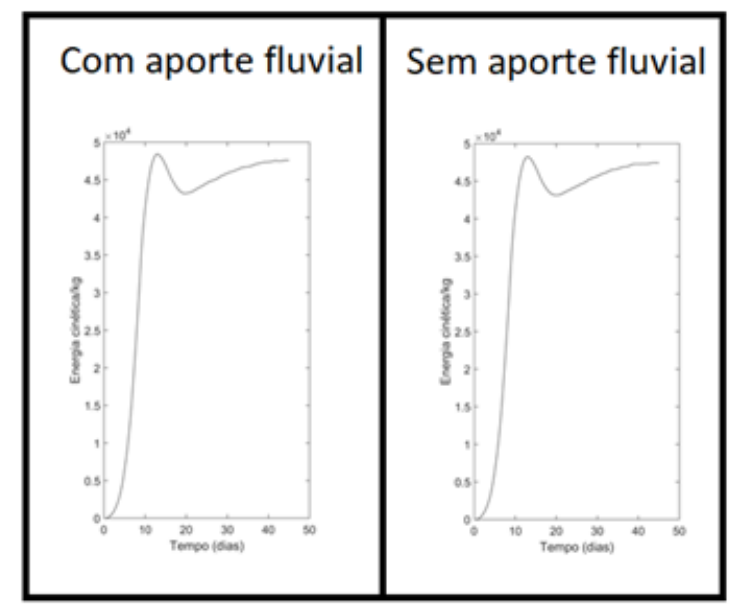

Figura 66 - Energia cinética em função do tempo para o mês de março, com e sem aporte fluvial e sem vento

Para as condições considerando o aporte fluvial e sem considerar o aporte fluvial (Figura 67), as correntes paralelas à costa são bastante similares, atingindo valores máximos chegando a $2 \mathrm{~m} . \mathrm{s}^{-1}$, com o núcleo da corrente ocorrendo na superfície.

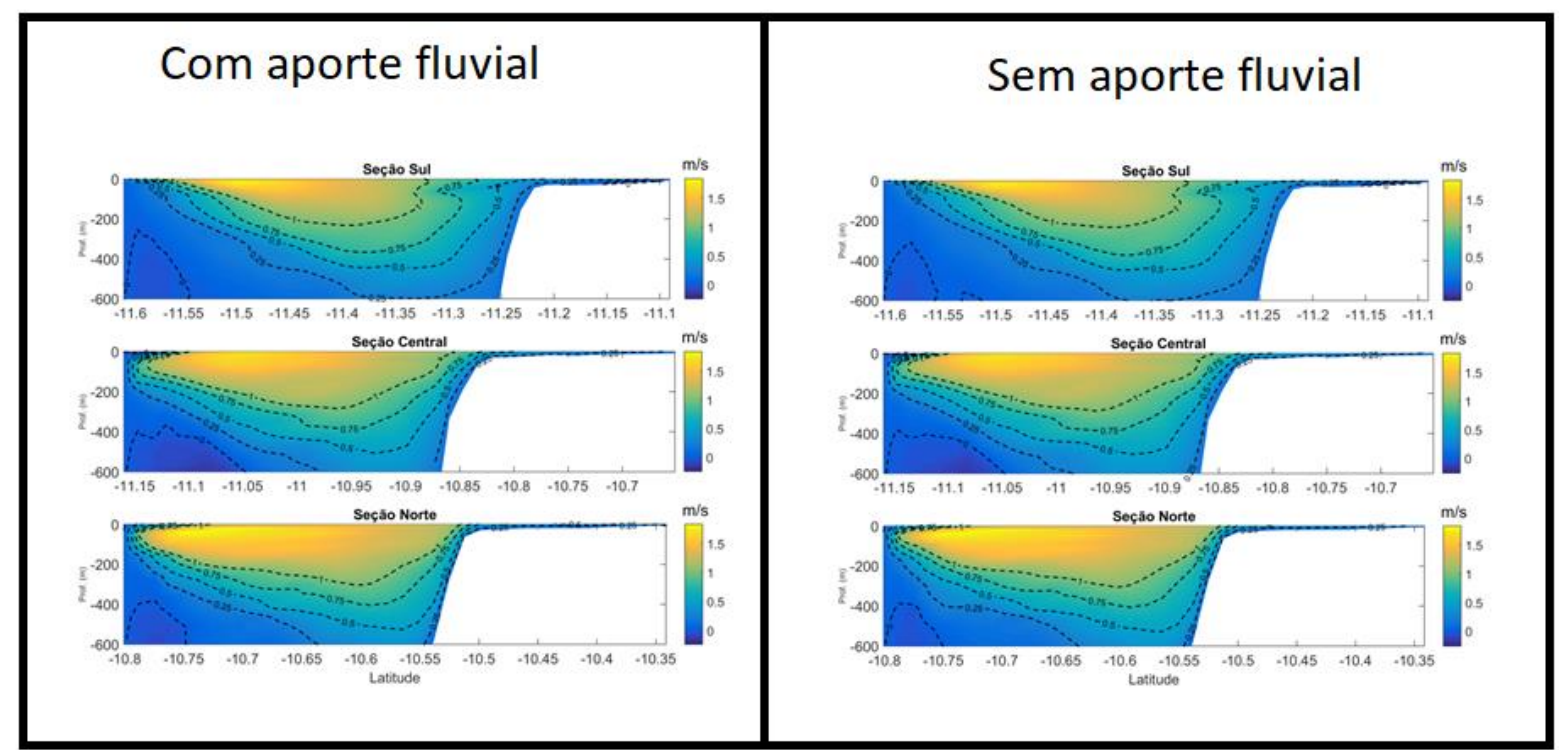

Figura 67 - Corrente no mês de março com e sem aporte fluvial e sem vento, nas seções Sul, Central e Norte. 
As correntes na seção do cânion de Japaratuba considerando aporte fluvial e sem considerar o aporte fluvial (Figura 68) são praticamente as mesmas, sendo as maiores diferenças entre 300 e $800 \mathrm{~m}$ de profundidade, próximo à borda Sul do cânion. As correntes são predominantemente positivas, sendo negativas entre $300 \mathrm{e}$ $900 \mathrm{~m}$, variando entre - 0,05 e 0,40 m.s $\mathrm{s}^{-1}$. Já no cânion do São Francisco, as correntes são praticamente as mesmas nas duas condições, sendo predominantemente positiva até $200 \mathrm{~m}$ de profundidade, e negativa abaixo, variando de $-0,05$ a 0,40 m.s.

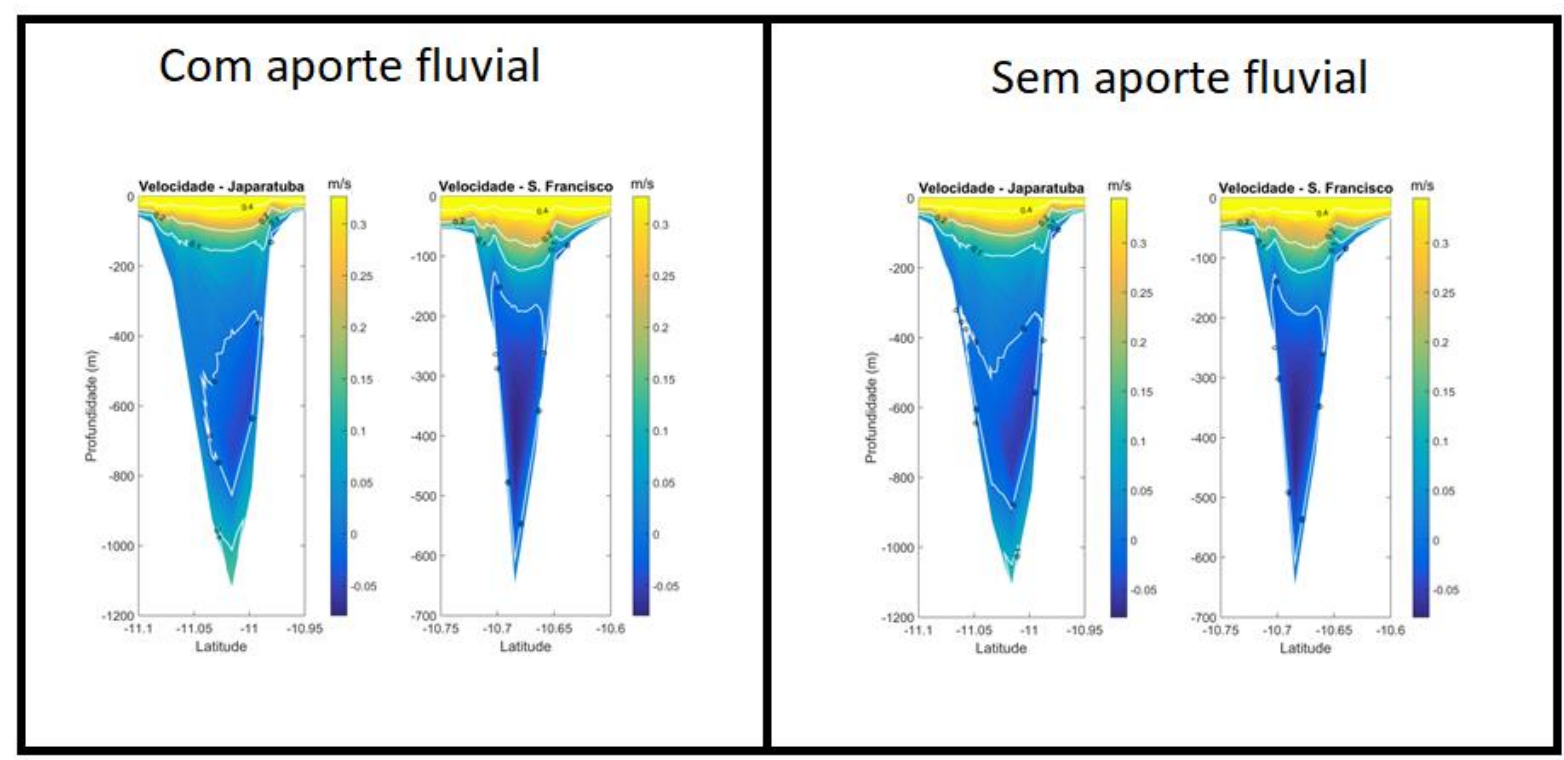

Figura 68 - Correntes nas seções dos cânions de Japaratuba e do São Francisco para o mês de março com e sem aporte fluvial e sem vento.

Para o cânion de Japaratuba (Figura 69 esq.), o transporte decresce com a profundidade até aproximadamente $600 \mathrm{~m}$, e cresce até $850 \mathrm{~m}$. O transporte, considerando a presença ou ausência de aporte fluvial é praticamente o mesmo. Até $350 \mathrm{~m}$, a condição sem aporte apresenta transporte ligeiramente maior que a condição com aporte, situação que se inverte para profundidades maiores que 350 m. $O$ transporte é positivo de 100 até $400 \mathrm{~m}$ de profundidade, e para profundidades maiores que $750 \mathrm{~m}$.

Já para o cânion do São Francisco (Figura 69 dir.), o transporte é negativo entre 150 e $550 \mathrm{~m}$ de profundidade, e positivo em profundidades menores que 150 $\mathrm{m}$ e maiores que $550 \mathrm{~m}$. Ocorre diminuição do transporte até a profundidade de 300 
$\mathrm{m}$, e aumento do transporte com a profundidade abaixo dos $300 \mathrm{~m}$. O transporte é praticamente o mesmo para todas as profundidades nos dois cenários.
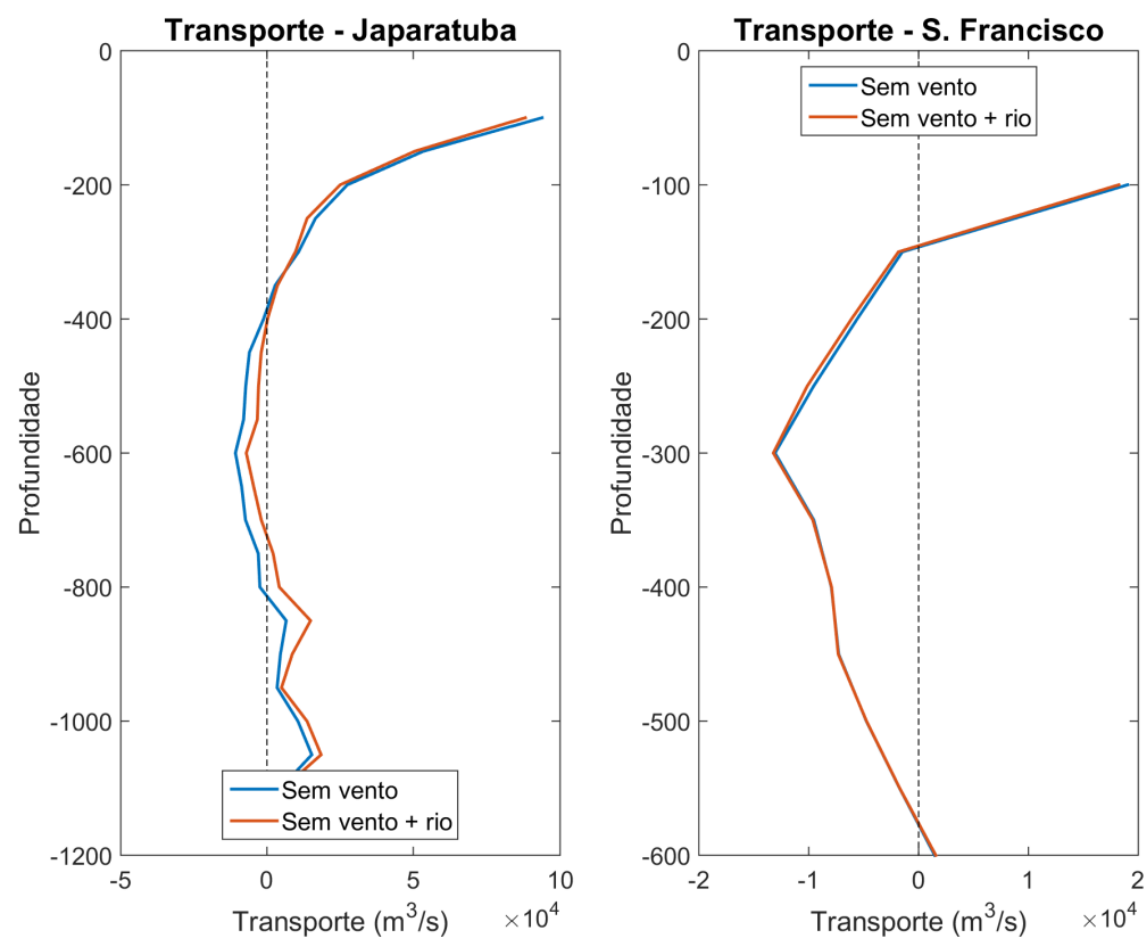

Figura 69 - Transporte em função da profundidade nas seções dos cânions de Japaratuba e São Francisco para o mês de março para as condições com e sem aporte fluvial.

\subsection{2 - Julho}

No cânion de Japaratuba (Figura 70), para a condição com aporte fluvial, a salinidade varia de 35 até 35,75 sendo mais salino em regiões mais rasas, enquanto a temperatura cai de $15^{\circ} \mathrm{C}$ em $100 \mathrm{~m}$ de profundidade até $5^{\circ} \mathrm{C}$ no fundo. Já no cânion de Sâo Francisco, a salinidade vai de 35,1 até 35,75 também mais salino em regiões mais rasas. Já a temperatura varia de $7^{\circ} \mathrm{C}$ até $15^{\circ} \mathrm{C}$. Os perfis de temperatura e salinidade para a condição sem aporte fluvial e sem vento (Figura 71) são praticamente idênticos aos perfis considerando aporte fluvial. 

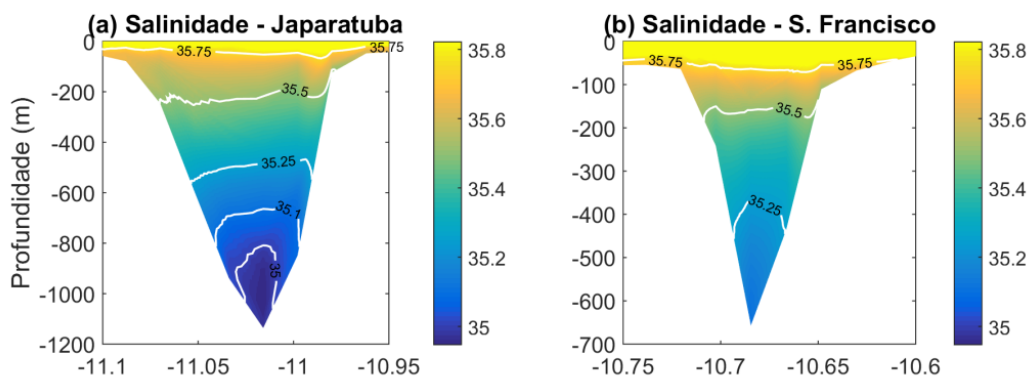

(c) Temperatura - Japaratuba $\left({ }^{\circ} \mathrm{C}\right)$
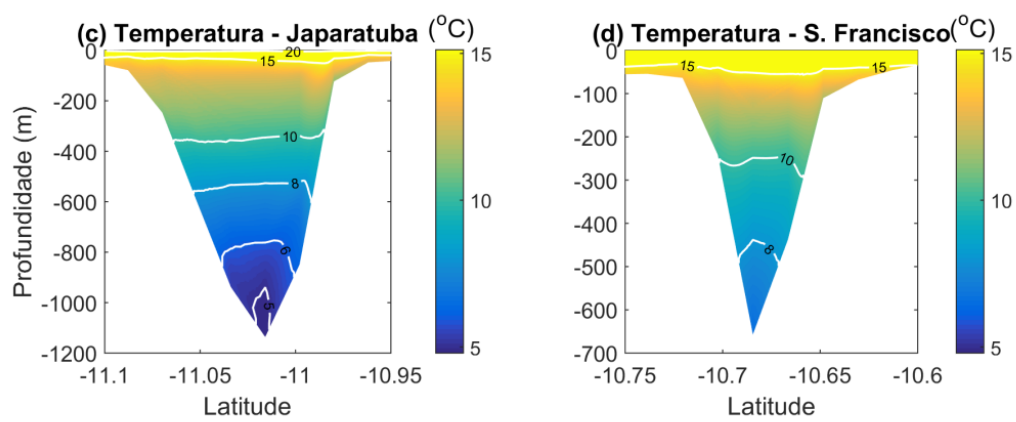

Figura 70 - Salinidade e temperatura nas seções dos cânions de Japaratuba e do São Francisco para o mês de julho com aporte fluvial e sem vento.
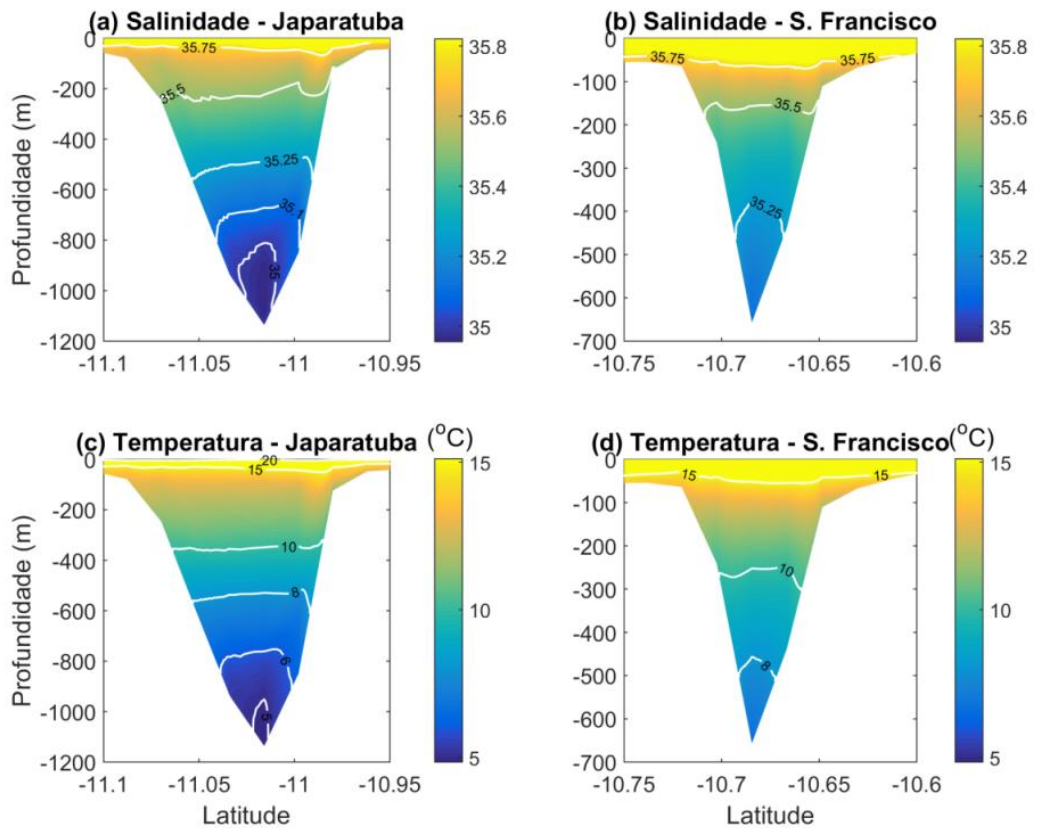

Figura 71 - Salinidade e temperatura nas seções dos cânions de Japaratuba e do São Francisco para o mês de julho sem aporte fluvial e sem vento. 
Para a condições considerando o aporte fluvial e sem considerar o aporte fluvial (Figura 72), as correntes paralelas à costa são bastante similares, atingindo valores máximos chegando a $2 \mathrm{~m} \cdot \mathrm{s}^{-1}$, com o núcleo da corrente ocorrendo na superfície. As correntes na simulação com aporte fluvial são maiores que a condição sem aporte.

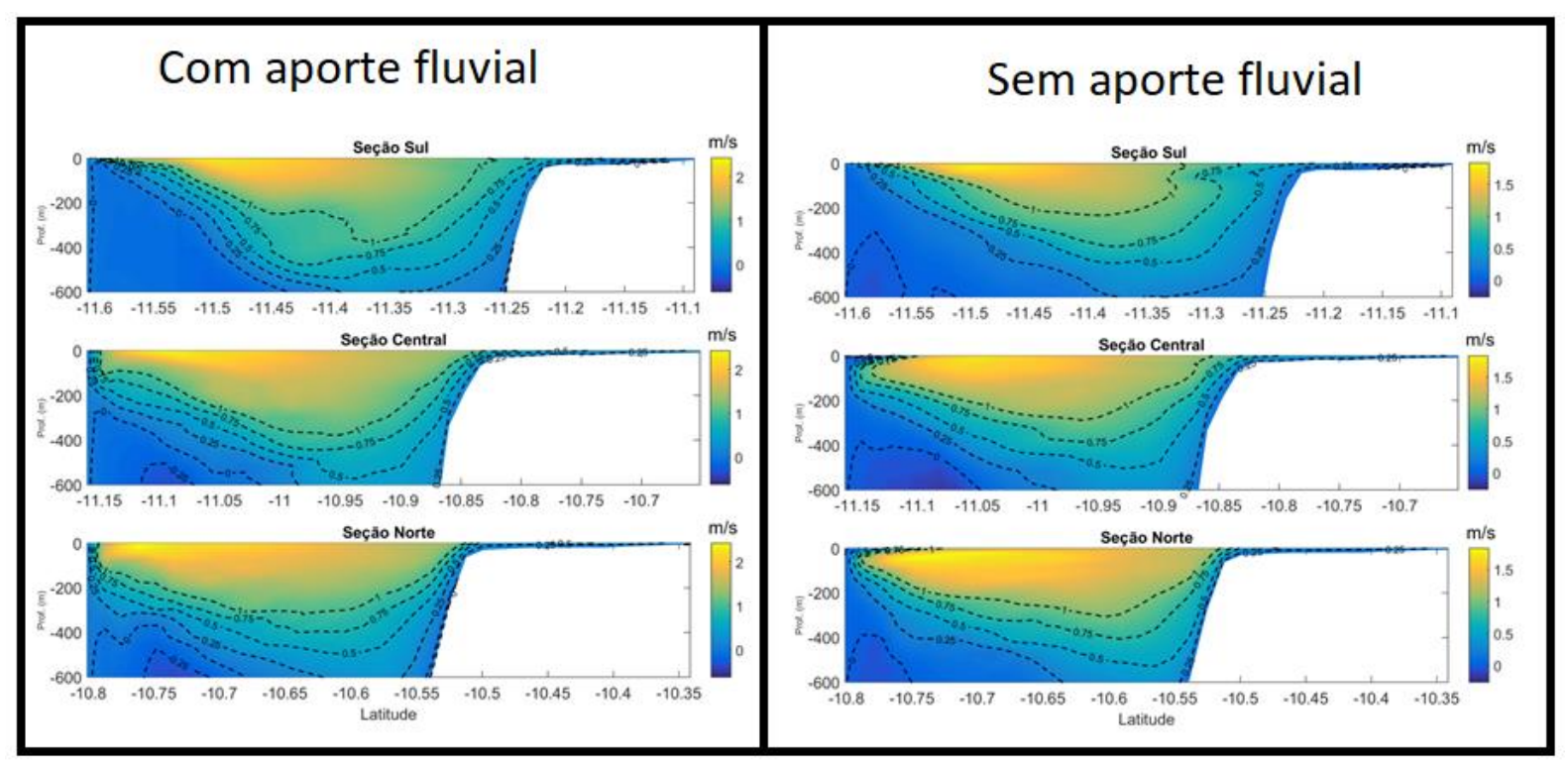

Figura 72 - Corrente no mês de Julho com e sem aporte fluvial e sem vento, nas seções Sul, Central e Norte.

As correntes na seção do cânion de Japaratuba considerando aporte fluvial e sem considerar o aporte fluvial (Figura 73) são praticamente as mesmas. As correntes são predominantemente positivas, sendo negativas entre 300 e $900 \mathrm{~m}$, variando entre - 0,05 e $0,40 \mathrm{~m} \cdot \mathrm{s}^{-1}$. No cânion do São Francisco as correntes também são praticamente as mesmas nas duas condições, sendo predominantemente positiva até $200 \mathrm{~m}$ de profundidade, e negativa abaixo, variando de - 0,05 a 0,40 $\mathrm{m} \cdot \mathrm{s}^{-1}$. 


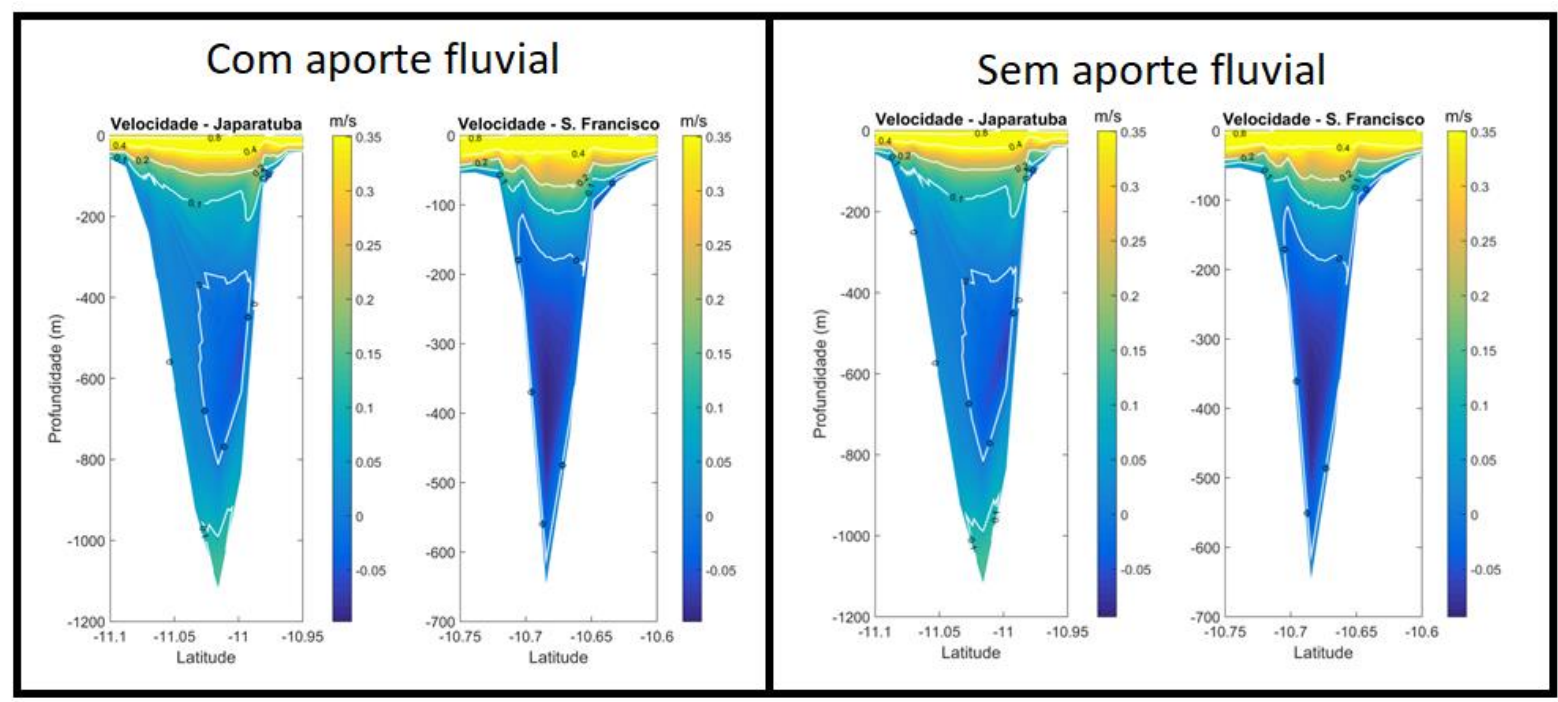

Figura 73 - Correntes nas seções dos cânions de Japaratuba e do São Francisco para o mês de julho com e sem aporte fluvial e sem vento.

Para o cânion de Japaratuba (Figura 74), o transporte decresce com a profundidade até aproximadamente $600 \mathrm{~m}$, e cresce até 850 . O transporte considerando a presença ou ausência de aporte fluvial é praticamente o mesmo. $\mathrm{O}$ transporte é positivo de 100 até $400 \mathrm{~m}$ de profundidade, e para profundidades maiores que $700 \mathrm{~m}$.

Já para o cânion do São Francisco, o transporte é negativo entre 150 e 550 m de profundidade, e positivo em profundidades menores que $150 \mathrm{~m}$ e maiores que $550 \mathrm{~m}$. Ocorre diminuição do transporte até a profundidade de $300 \mathrm{~m}$, e aumento do transporte com o aumento da profundidade abaixo dos $300 \mathrm{~m}$. O transporte é praticamente o mesmo para todas as profundidades nas duas condições, sendo maior na condição de ausência de aporte fluvial. 

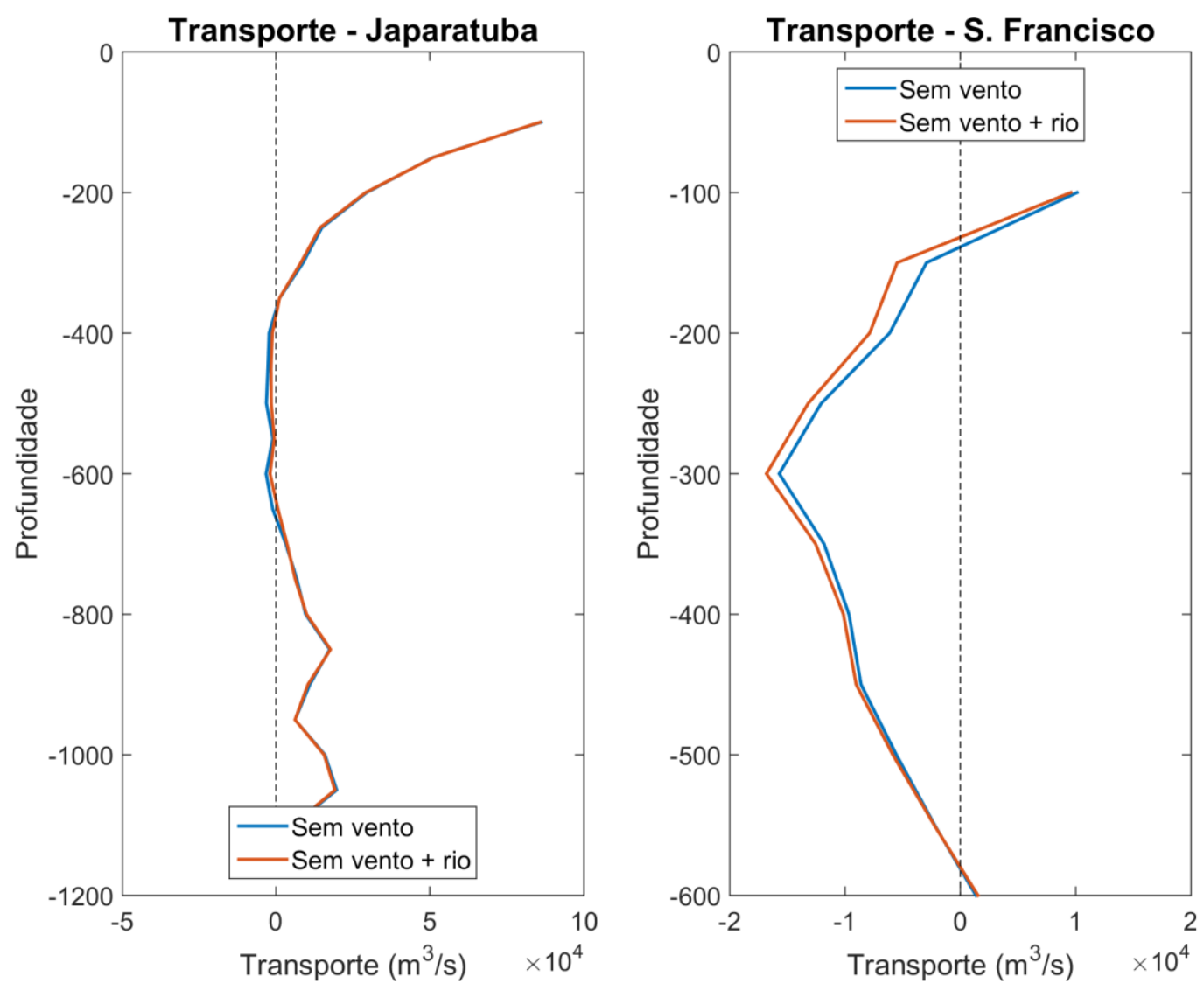

Figura 74 - Transporte em função da profundidade nas seções dos cânions de Japaratuba e São Francisco para o mês julho para as condições com e sem aporte fluvial.

\subsection{3 - Setembro}

Da mesma forma que nos meses anteriores, no mês de setembro, o perfil de temperatura e salinidade para as condições com (Figura 75) e sem (Figura 76) aporte fluvial, e também as correntes nas seções perpendiculares à costa (Figura 77), e as velocidades nas seções dos cânions (Figura 78) são praticamente os mesmos. 

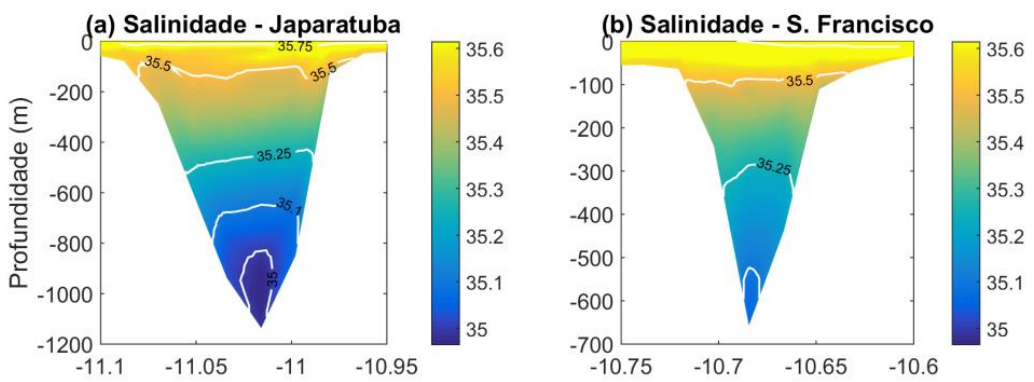

(c) Temperatura - Japaratuba $\left({ }^{\circ} \mathrm{C}\right)$

(d) Temperatura - S. Francisco $\left({ }^{\circ} \mathrm{C}\right)$
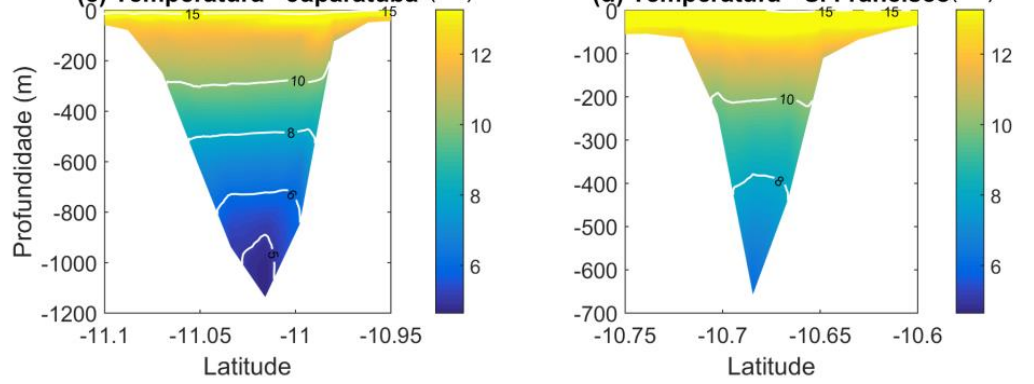

Figura 75 - Salinidade e temperatura nas seções dos cânions de Japaratuba e do São Francisco para o mês de setembro com aporte fluvial e sem vento.
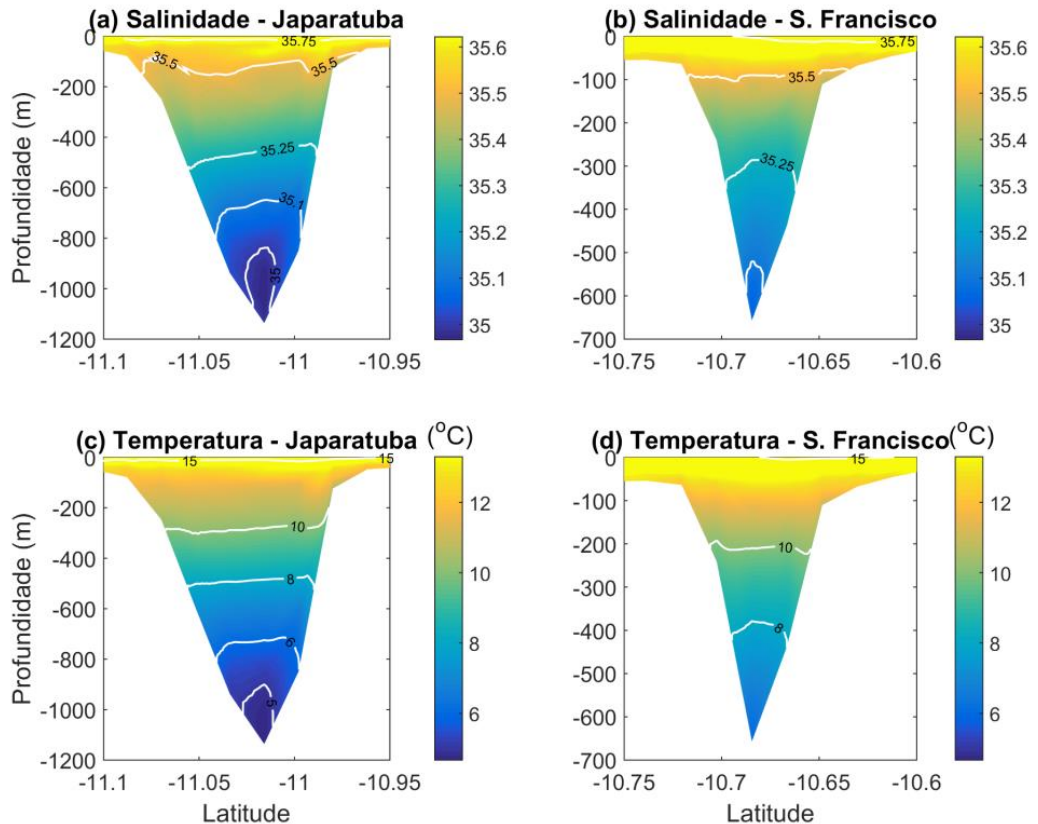

Figura 76 - Salinidade e temperatura nas seções dos cânions de Japaratuba e do São Francisco para o mês de setembro sem aporte fluvial e sem vento. 


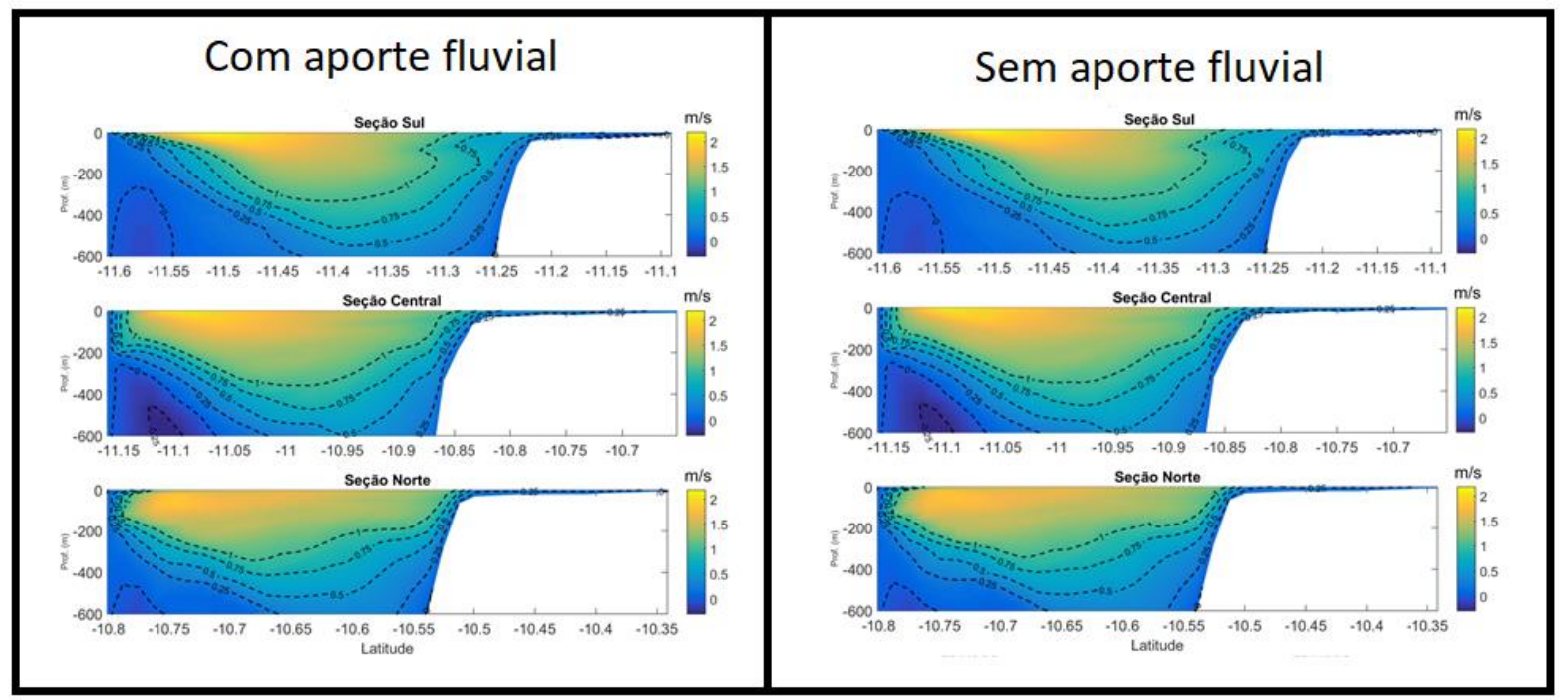

Figura 77 - Corrente no mês de setembro com e sem aporte fluvial e sem vento, nas seções Sul, Central e Norte.

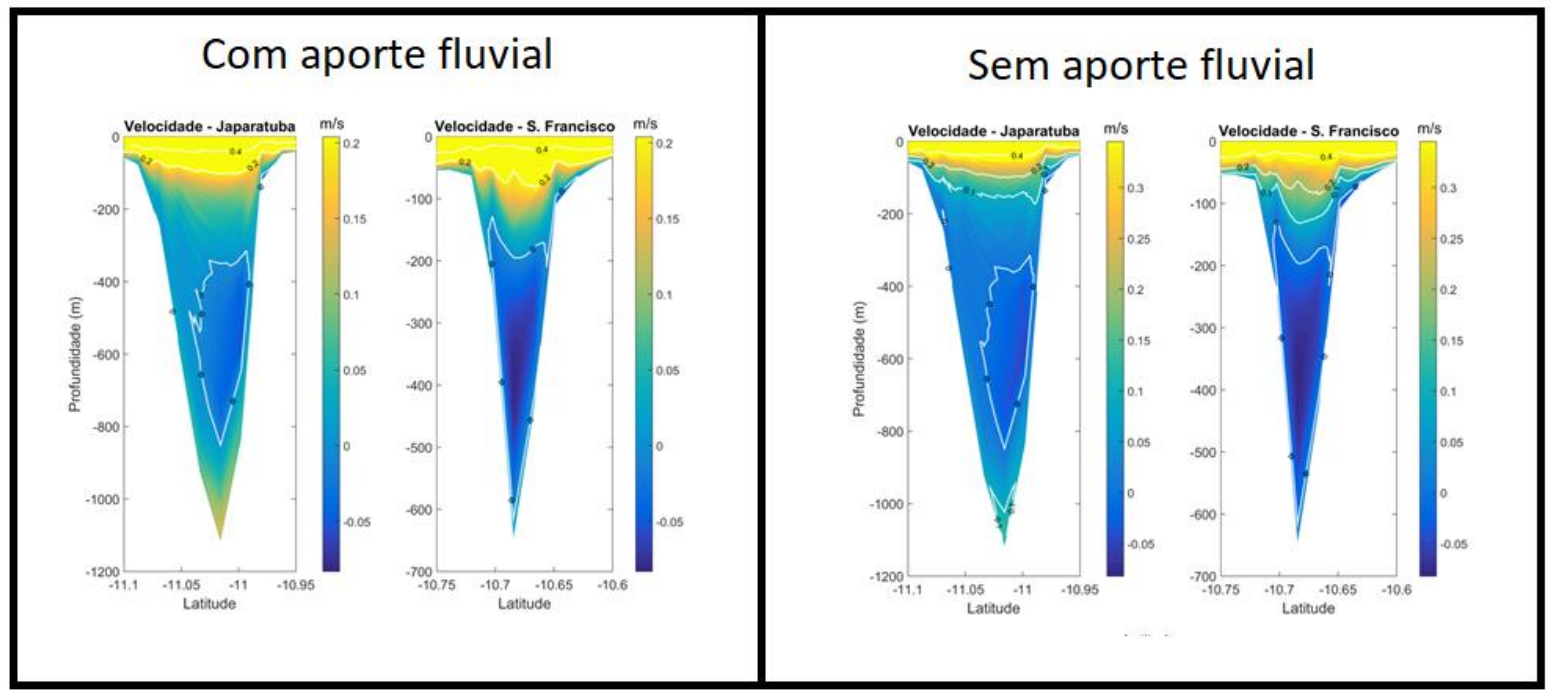

Figura 78 - Correntes nas seções dos cânions de Japaratuba e do São Francisco para o mês de setembro com e sem aporte fluvial e sem vento. 

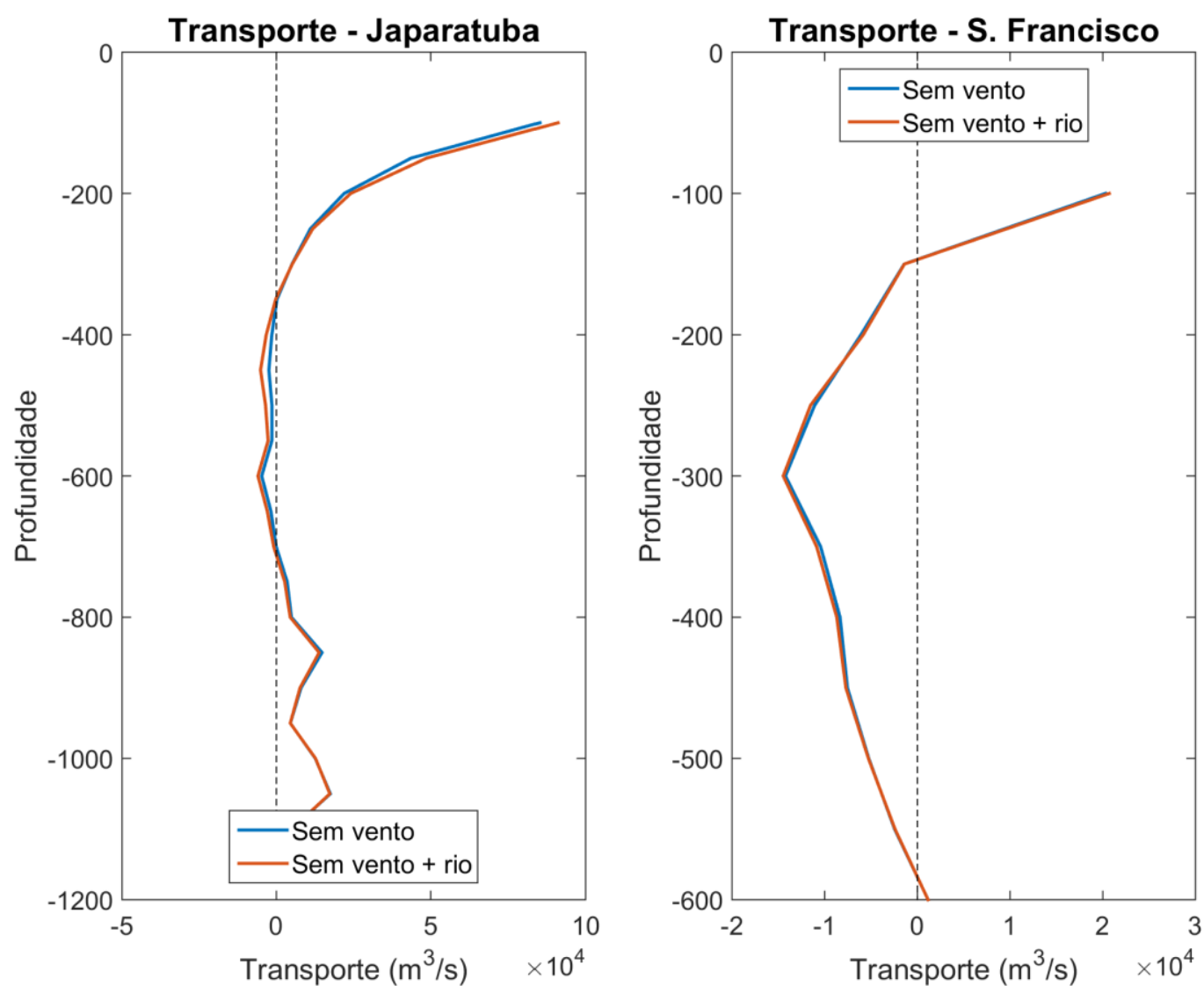

Figura 79 - Transporte em função da profundidade nas seções dos cânions de Japaratuba e São Francisco para o mês de setembro para as condições com e sem aporte fluvial.

Para o cânion de Japaratuba (Figura 79), o transporte perpendicular à costa decresce com a profundidade até aproximadamente $600 \mathrm{~m}$, e cresce até 850 . O transporte considerando a presença ou ausência de aporte fluvial é praticamente a mesma. Até $300 \mathrm{~m}$, a condição com aporte apresenta transporte ligeiramente maior que a condição sem aporte, situação que se inverte para profundidades maiores que $300 \mathrm{~m}$. O transporte é positivo de 100 até $400 \mathrm{~m}$ de profundidade, e para profundidades maiores que $700 \mathrm{~m}$.

Já para o cânion do São Francisco, o transporte perpendicular à costa é negativo entre 150 e $550 \mathrm{~m}$ de profundidade, e positivo em profundidades menores que $150 \mathrm{~m}$ e maiores que $550 \mathrm{~m}$. Ocorre diminuição do transporte até a profundidade de $300 \mathrm{~m}$, e aumento do transporte com o aumento da profundidade abaixo dos $300 \mathrm{~m}$. O transporte é praticamente o mesmo para todas as profundidades nas duas condições, na presença e ausência de aporte fluvial. 
$\mathrm{Na}$ Tabela 3 são apresentados os transportes referentes a diversos cenários simulados, com ausência e presença de ventos e aporte fluvial. Em todos os cenários considerando presença de ventos, não é considerado aporte fluvial junto, e os resultados (B) são comparados para a condição sem vento e sem aporte (A), para avaliar a influência da ação dos ventos. Também é feita uma comparação de um cenário com aporte fluvial e sem vento (C) com a condição sem aporte e sem vento (D), para avaliar a influência da ação do aporte fluvial. A comparação dos cenários com e sem ventos apresentam resultados diversos dependendo do mês simulado e a condição de vento. Para todas as simulações foram observados transportes positivos para o cânion de Japaratuba, e transportes negativos para o cânion do São Francisco, indicando fluxo de regiões mais rasas em direção a regiões mais profundas para o primeiro caso, e no sentido contrário no segundo.

Para o mês de março ( $\mathrm{A}$ e B), a condição que apresentou maior transporte no cânion de Japaratuba foi para ventos de Nordeste, seguido por ventos de Leste, sem vento, ventos de Sudeste, e ventos de Sul. Já para o cânion do São Francisco, também no mês de março, a condição de vento que apresentou o transporte mais negativo foi para ventos de Leste, seguido por ventos de Nordeste, sem vento, depois por ventos de Sudeste, com ventos de Sul apresentando o menor transporte.

Para o mês de julho ( $\mathrm{A}$ e B), no cânion de Japaratuba, a condição de vento que apresentou maior transporte foi para vento de Leste, seguido por ventos de Sudeste, sem vento, Nordeste, e Sul. No cânion do São Francisco a condição que apresentou transporte mais negativo foi para o cenário sem vento, seguido por ventos de Nordeste, Sul, Sudeste e Leste.

Por fim, no mês de setembro (A e B), no cânion de Japaratuba, o maior transporte foi apresentado para ventos de Nordeste, seguido por ventos de Leste, sem vento, de Sudeste e de Sul. No cânion do São Francisco, vento de Leste apresentou transporte mais negativo, seguido pelo cenário sem vento, ventos de Nordeste, Sul e Sudeste. 
Tabela 3 - Fluxo de volume $\left(\times 10^{6} \mathrm{~m}^{3} / \mathrm{s}\right)$ através da seção dos cânions em diferentes cenários de vento e aporte fluvial. Valores positivos indicam fluxo dos cânions em direção ao oceano aberto, e valores negativos indicam fluxo do oceano aberto em direção aos cânions. ID é a identificação de cada uma das simulações.

\begin{tabular}{|c|c|c|c|c|c|c|c|}
\hline \multirow{2}{*}{$\begin{array}{l}\text { Vento/ } \\
\text { Rios }\end{array}$} & \multicolumn{2}{|c|}{ Março } & \multicolumn{2}{|c|}{ Julho } & \multicolumn{2}{|c|}{ Setembro } & \multirow[t]{2}{*}{ ID } \\
\hline & Japaratuba & $\begin{array}{c}\text { S. } \\
\text { Francisco }\end{array}$ & Japaratuba & $\begin{array}{c}\text { S. } \\
\text { Francisco }\end{array}$ & Japaratuba & $\begin{array}{c}\text { S. } \\
\text { Francisco }\end{array}$ & \\
\hline $\begin{array}{c}\text { Sem } \\
\text { vento } \\
\text { Sem } \\
\text { aporte }\end{array}$ & 1,45 & $-0,86$ & 0,54 & $-0,58$ & 1,26 & $-0,75$ & $A$ \\
\hline $\begin{array}{c}\text { Nordeste } \\
\text { Sem } \\
\text { aporte }\end{array}$ & 1,69 & $-0,94$ & 0,38 & $-0,40$ & 1,60 & $-0,70$ & \\
\hline $\begin{array}{c}\text { Leste } \\
\text { Sem } \\
\text { aporte }\end{array}$ & 1,59 & $-1,00$ & 0,96 & $-0,01$ & 1,48 & $-0,80$ & \\
\hline $\begin{array}{c}\text { Sudeste } \\
\text { Sem } \\
\text { aporte }\end{array}$ & 0,84 & $-0,53$ & 0,89 & $-0,27$ & 1,15 & $-0,60$ & B \\
\hline $\begin{array}{c}\text { Sul } \\
\text { Sem } \\
\text { aporte }\end{array}$ & 0,66 & $-0,52$ & 0,37 & $-0,35$ & 1,02 & $-0,60$ & \\
\hline $\begin{array}{l}\text { Sem } \\
\text { vento } \\
\text { Com } \\
\text { aporte }\end{array}$ & 2,27 & $-0,46$ & 3,14 & $-0,75$ & 2,57 & $-0,50$ & C \\
\hline $\begin{array}{c}\text { Sem } \\
\text { vento } \\
\text { Sem } \\
\text { aporte }\end{array}$ & 2,27 & $-0,46$ & 3,13 & $-0,77$ & 2,57 & $-0,50$ & D \\
\hline
\end{tabular}


Já na comparação dos cenários sem vento (C e D), ao adicionar aporte fluvial como forçante $(C)$, houve variação de transporte bastante reduzida, entre - 0,3\% e + 0,3\% para o cânion de Japaratuba, e entre $-0,1 \%$ e $+4,0 \%$ para o cânion do São Francisco. Desta forma, a variação de transporte não ultrapassa $4,0 \%$ ao se adicionar aporte fluvial nas simulações.

Independente da condição de vento e de aporte fluvial (ausentes ou presentes), e de qual mês foi simulado, para o cânion de Japaratuba todos os transportes observados são positivos, enquanto que para o cânion do São Francisco são negativos. Considerando a ação dos ventos, para o cânion de Japaratuba, a condição que apresenta menores valores de transporte em todos os meses ocorreu para ventos de Sul, e maiores valores para ventos de Nordeste e de Leste. Para o cânion do São Francisco a condição que apresentou transporte mais negativo foi para ventos de Nordeste e Leste, e os menores valores para ventos de Sudeste e Sul. A condição sem vento ficou como intermediária nos meses de março e julho, e com transporte mais negativo em setembro. 


\section{3 - Simulação com dados de vento variáveis (E)}

Foram realizadas simulações com dados de vento variáveis (dados do NCEP) para os meses de março, julho e setembro sem considerar o aporte fluvial. Foram escolhidos esses meses para acompanhar possíveis diferenças dependendo do mês analisado. Para cada mês, foi realizada simulação de 45 dias, sendo que os primeiros 15 dias são de aquecimente e não estão apresentados, e os 30 dias posteriores de simulação, que foram analisados.

\subsection{1 - Março}

No mês de março, os ventos variam em ângulo de incidência entre $60^{\circ}$ e $120^{\circ}$ (Figura 80a). Entre os dias 22 e 30 há predomínio de ventos com ângulo de incidência menores que $90^{\circ}$, ou seja, entre ventos de Nordeste a ventos de Leste. Já entre os dias 1 e 21 há predomínio de ventos com ângulo de incidência entre 90 e $145^{\circ}$, ou seja, entre ventos de Leste a ventos de Sudeste. Os ventos paralelos à costa mais intensos ocorrem entre os dias 8 e 11, e entre os dias 22 e 30.

Para o cânion de Japaratuba, os transportes são sempre positivos, sendo que ocorrem duas diminuições e um aumento de transportes a serem observados. Nos dois períodos de queda do transporte, entre os dias 3 e 6 , e entre os dias 10 e 17, o ângulo de incidência dos ventos é maior que $90^{\circ}$. A primeira queda é mais intensa que a segunda, uma vez que a intensidade do vento paralelo à costa é maior na primeira queda. Já no período de aumento de transporte, entre os dias dias 6 e 10, o ângulo de incidência dos ventos é menor que $90^{\circ}$, e a intensidade do vento paralelo à costa é máxima no período analisado, chegando a $-13 \mathrm{~m} \cdot \mathrm{s}^{-1}$. Assim, o transporte no cânion de Japaratuba foi máximo para vento de Leste intenso.

Para o cânion do São Francisco, os transportes foram sempre negativos, sendo mais negativos entre os dias 17 e 30 . Neste período, o ângulo de incidência do vento é menor que $90^{\circ}$. Outro período com transporte mais intenso foi entre os dias 1 e 4, quando os ventos são entre Leste e Sudeste e pouco intensos. Entre os dias 6 e 16, ocorrem os transportes negativos menos intensos, atingindo o mínimo no dia 9 , quando a intensidade do vento paralelo a costa é o mais intenso, chegando a - $13 \mathrm{~m} \cdot \mathrm{s}^{-1}$, e o ângulo de incidência do vento é predominantemente de Leste. 


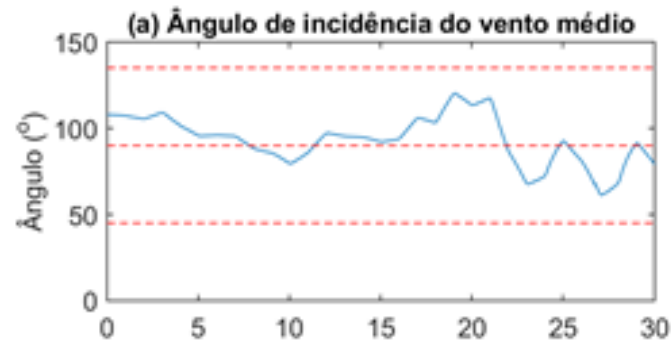

(c) Vento paralelo
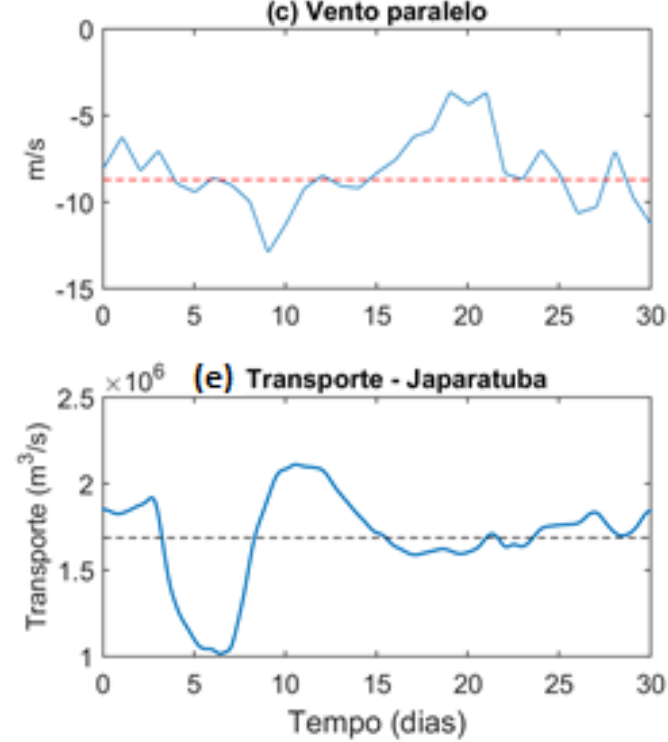

(b) Intensidade do vento médio

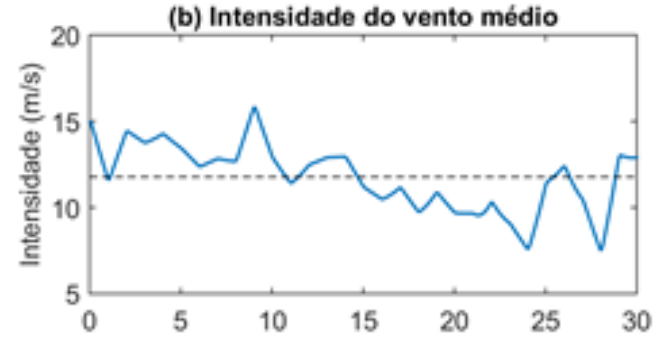

(d) Vento perpendicular
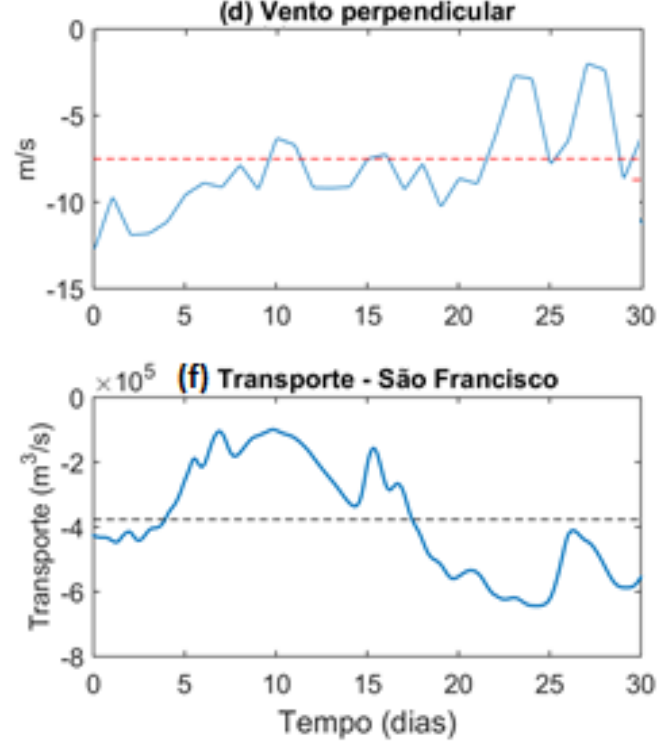

Figura 80 - Ângulo de incidência e intensidade do vento médio, e transporte na seção dos cânions de Japaratuba e São Francisco para o mês de março. As linhas pontilhadas indicam a média no período.

\subsection{2 - Julho}

No mês de julho, os ventos variam em ângulo de incidência entre $85^{\circ}$ e $150^{\circ}$ (Figura 81a). Entre os dias 10 e 25, há predomínio de ventos com ângulo de incidência entre 90 e 135을 ou seja, entre ventos de Leste e de Sudeste. Já nos outros períodos há predomínio de ventos com ângulo de incidência acima de 145으, ou seja, entre ventos de Sudeste e Sul. Os ventos paralelos à costa mais intensos ocorrem entre os dias 12 e 14, e entre os dias 21 e 23. 
(a) Ângulo de incidência do vento médio

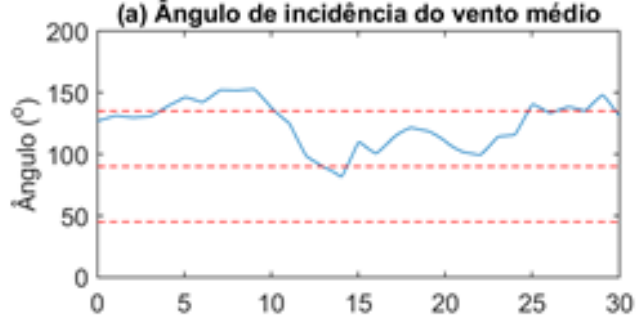

(c) Vento paralelo
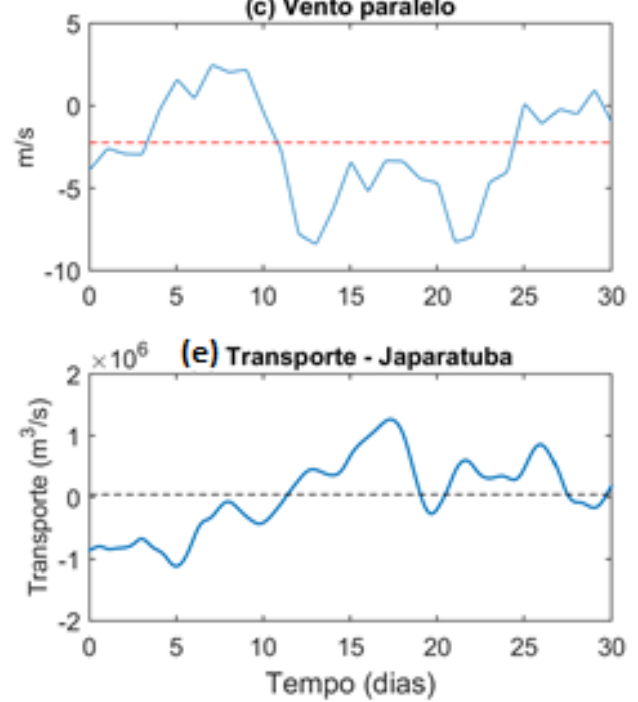

(b) Intensidade do vento médio

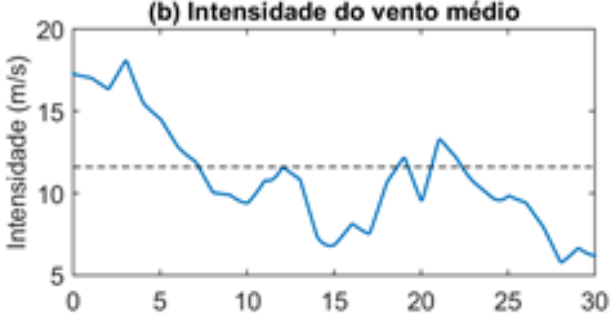

(d) Vento perpendicular
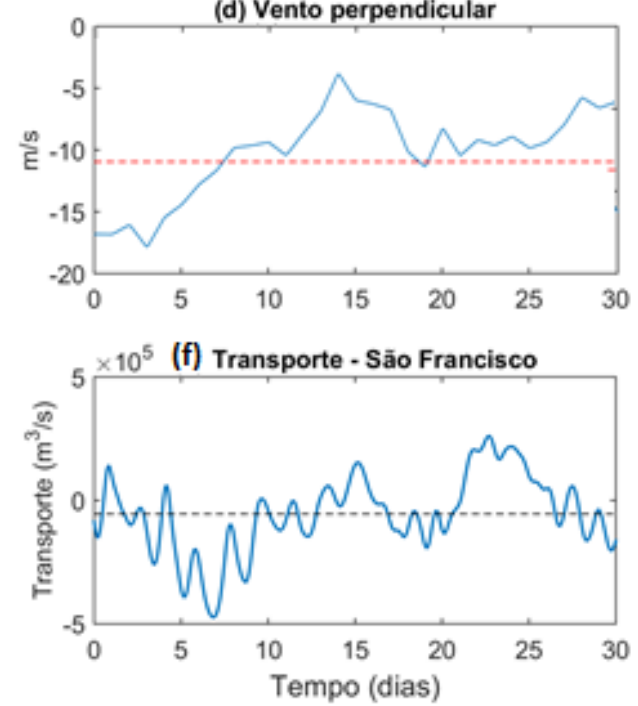

Figura 81 - Ângulo de incidência e intensidade do vento médio, e transporte na seção dos cânions de Japaratuba e São Francisco para o mês de julho. As linhas pontilhadas indicam a média no período.

Para o cânion de Japaratuba, o transporte alternou entre positivo e negativo, sendo predominantemente negativo entre os dias 1 e 12, e entre os dias 27 e 30, e predominantemente positivo nos outros períodos. Nos períodos de transporte negativo, o vento é predominantemente de entre Sudeste e Sul e o vento paralelo à costa é pouco intenso. O transporte mais positivo ocorre entre os dias 15 e 18, quando o vento paralelo é mais intenso e está entre Leste e Sudeste.

Para o cânion do São Francisco, o transporte também alternou entre positivo e negativo, sendo predominantemente negativo entre os dias 1 e 12 , e predominantemente positivo entre os dias 13 e 25 . No período em que o transporte é positivo, o ângulo de incidência do vento está entre $90^{\circ}$ e 145으, e a intensidade do vento paralelo à costa apresenta valores máximos, chegando a $8 \mathrm{~m} \cdot \mathrm{s}^{-1}$ nos dias $13 \mathrm{e}$ 22. $O$ transporte negativo ocorre para ventos de Sudeste, e a intensidade do vento paralelo à costa é mais baixa. 


\subsection{3 - Setembro}

No mês de setembro, os ventos variam em ângulo de incidência entre $80^{\circ} \mathrm{e}$ $150^{\circ}$ (Figura 82a), sendo que durante quase todo o período, varia de 90 a 135º , ou seja, entre ventos de Leste e de Sudeste. Os menores ângulos de incidência ocorrem entre os dias 8 e 22. Os ventos paralelos à costa mais intensos ocorrem entre os dias 1 e 23.

Para o cânion de Japaratuba, o transporte foi sempre positivo, sendo que há uma tendência de aumento do dia 1 ao dia 23, e posterior diminuição. O ângulo de incidência do vento diminui do dia 1 ao dia 18, e depois aumenta até o dia 28. Neste período ocorrem os ventos paralelos à costa mais intensos. Entre os dias 25 e 30 ocorre diminuição do transporte, sendo que o vento é predominantemente de Sudeste e com vento paralelo à costa fraco.

Para o cânion do São Francisco, o transporte alternou entre positivo e negativo, sendo predominantemente positivo entre os dias 7 e 19, e predominantemente negativo nos demais períodos. No período em que o transporte é positivo, os ventos são predominantemente de Leste, e a intensidade do vento paralelo é costa é máximo no período. Nos períodos com transporte negativo, os ventos são entre Leste e Sudeste e de baixa intensidade do vento paralelo à costa. 

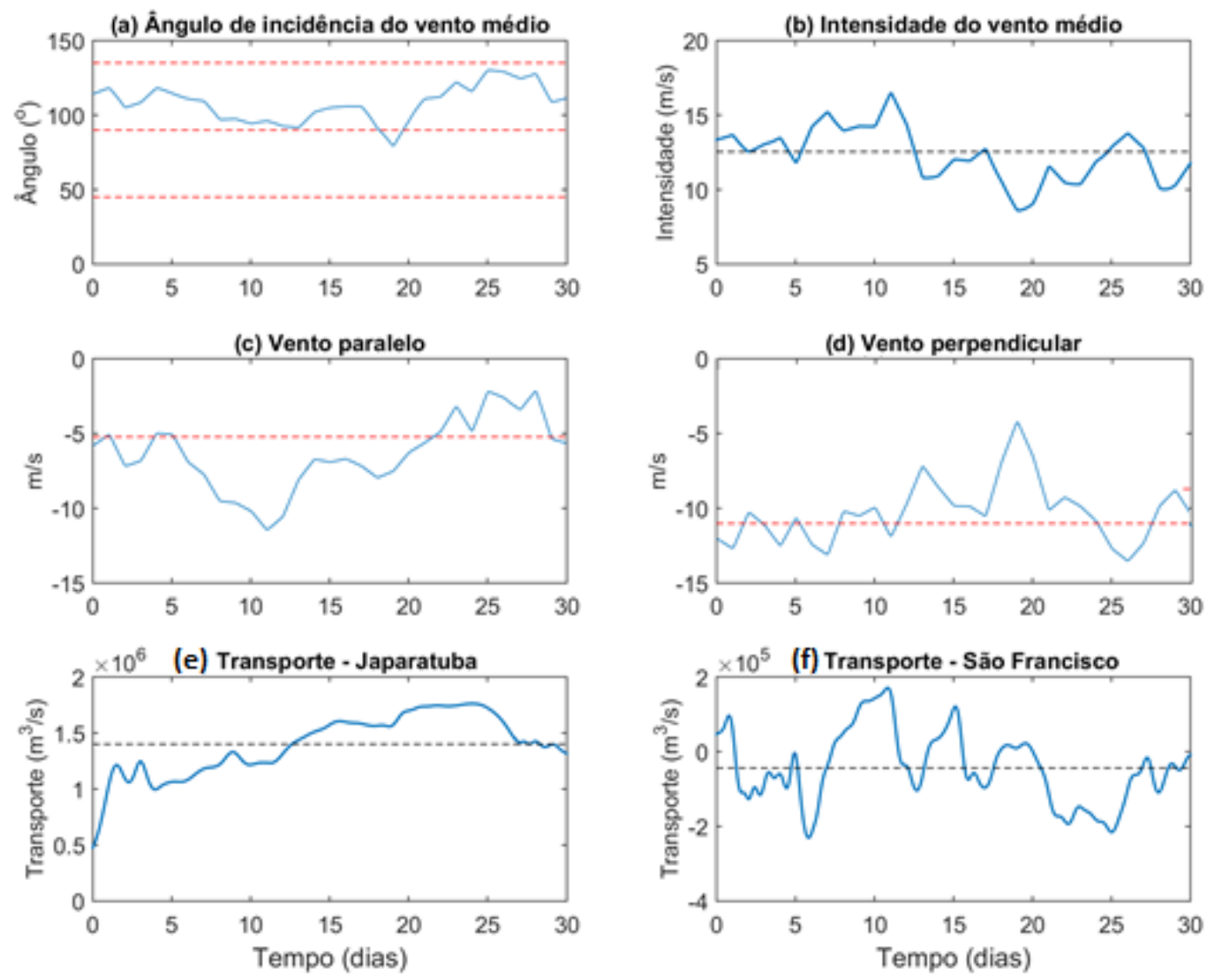

Figura 82 - Ângulo de incidência e intensidade do vento médio, e transporte na seção dos cânions de Japaratuba e São Francisco para o mês de setembro. As linhas pontilhadas indicam a média no período. 


\section{4 - Discussão}

Foram realizadas simulações utilizando dados de temperatura $(T)$ e salinidade (S) referentes aos meses de março, julho e setembro de 2014, sendo esses dados médios dos meses, com o objetivo de gerar a SNB e avaliar seus efeitos na circulação em conjunto com a ação de ventos e aporte fluvial. Tais dados de $T$ e $S$ inseridos no modelo estão apresentados em diagramas TS referentes a cada um dos meses na Figura 9, sendo que eles são coerentes com aqueles obtidos por Silveira et. al (1994) apresentados na Figura 10, com a presença das massas d'água AT, ACAS e AIA nos dados utilizados, além dos valores máximos e mínimos de $T$ e $S$ estarem próximos.

Com os dados dos campos de $T$ e $S$ de acordo com as características da região, foi possível realizar simulações em que se formou a SNB, sendo que seu núcleo variou entre 100 e $400 \mathrm{~m}$ de profundidade dependendo da condição simulada, e valores máximos entre 0,8 e $1,2 \mathrm{~m} \cdot \mathrm{s}^{-1}$. Silveira et. al (1994) obtiveram o núcleo da SNB entre 100 e $200 \mathrm{~m}$ de profundidade, e valores máximos de $0,5 \mathrm{~m} \cdot \mathrm{s}^{-1}$ (Figura 2). Desta forma, foi possível simular a SNB ocorrendo em subsuperfície, mas com intensidades maiores do que o observado. Não foi possível, entretanto, obter a SNB em subsuperfície nas simulações envolvendo a ação do aporte fluvial, quando foi utilizado o modo prognóstico, ou seja, $T$ e $S$ variando no tempo, quando o núcleo da SNB obtido estava na superfície e com intensidade maior que $1,5 \mathrm{~m} \cdot \mathrm{s}^{-1}$.

Antes de discutir a influência de cada direção de vento na circulação e transporte, é necessário discutir as diferenças entre cada um dos meses. Para isso, avaliamos as diferenças nas condições que o vento não é considerado (cenários $A$ ) em cada um dos 3 meses. Os meses de julho e setembro apresentam campos de $T$ e $S$ praticamente idênticos, enquanto o mês de março apresenta algumas diferenças em relação a esses meses (Figura 9). O mês de março apresentou águas mais frias e mais salinas nas regiões mais rasas onde há ocorrência da AT, enquanto que em regiões mais profundas, onde há ocorrência da ACAS e da AIA, apresentou maior salinidade do que nos outros meses. Essas diferenças de $T$ e $S$ causam diferentes densidades na coluna d'água entre os meses, alterando o gradiente de pressão baroclínico, e consequentemente alterando a circulação. 
A circulação em 100, 200, 300 e $400 \mathrm{~m}$ de profundidade mostra que as correntes no mês de setembro (Figura 13) são as mais intensas, seguido pelo mês de março (Figura 11), e as menos intensas ocorrendo em julho (Figura 12). Na Figura 14 pode ser observado que o mês de setembro apresenta correntes mais intensas nas 3 seções perpendiculares à costa. Já o mês de julho apresenta as correntes menos intensas na seção Norte, enquanto que março apresenta as correntes menos intensas nas outras duas seções.

Apesar do mês de setembro apresentar as correntes mais intensas na condição sem vento, é o mês de março que apresenta os maiores transportes nos dois cânions (Tabela 3), sendo o mais positivo no caso do cânion de Japaratuba, e o mais negativo no cânion do São Francisco. Já o mês de julho apresenta os menores transportes dentre os 3 meses simulados.

Pela Figura 17 é possível verificar que entre 100 e $350 \mathrm{~m}$ de profundidade o mês de março apresenta transporte maior que os outros meses para o cânion de Japaratuba, o que pode ser visto também na Figura 15, onde a área de correntes positivas é maior que nos outros meses. Também é possível observar que na borda Sul, o mês de março é o único que não apresenta transporte negativo, sendo positivo abaixo de $250 \mathrm{~m}$. O mês de julho apresenta transporte negativo entre $100 \mathrm{e}$ $250 \mathrm{~m}$, o que explica ser o mês com menor transporte. Os 3 meses apresentam perfis bastante distintos entre a superfície e $100 \mathrm{~m}$ de profundidade.

Já para o cânion do São Francisco, verificamos pela Figura 17 que o mês de Março apresenta o transporte mais negativo entre 50 e $400 \mathrm{~m}$ de profundidade, o que pode ser observado na Figura 16, onde é notável que o transporte é mais negativo entre a superfície e $50 \mathrm{~m}$ de profundidade para os meses de julho e setembro, sendo mais abaixo para o mês de março esse mínimo.

Foi mostrado que ao adicionarmos vento nas simulações (cenários B) ocorrem mudanças na circulação na região de estudo. Mais precisamente nas proximidades dos cânions, foi observado através de seções perpendiculares à costa que as correntes mudam quando o vento é adicionado, se tornando mais ou menos intensas, dependendo do mês e da condição de vento. Também pudemos observar através das seções nos cânions que o transporte dentro deles é alterado a cada condição de vento, variando em intensidade e direção do fluxo. Para todas as condições de ventos constantes simulados, o cânion de Japaratuba apresentou 
transporte integrado ao longo da coluna d'água positivo, enquanto que o cânion do São Francisco apresentou transporte negativo.

Com relação ao cânion de Japaratuba, a condição de vento de Nordeste apresentou o maior transporte nos meses de março e setembro, enquanto que a condição de vento de Leste apresentou o maior transporte em julho, e o segundo maior transporte nos outros meses (Tabela 3). Já os menores transportes ocorreram para ventos de Sudeste e de Sul, com a única excessão sendo ventos de Nordeste em Julho, que apresentou transporte entre os mais baixos. A condição sem vento se apresentou como uma condição intermediária, com transporte menor que ventos de Nordeste e de Leste, e apresentando transporte maior que ventos de Sudeste e de Sul, em quase todos os casos, exceto ventos de Nordeste em julho.

Avaliando o transporte a cada mês, em função da profundidade, é possível verificar em quais profundidades ocorrem as diferenças mais significativas do transporte, fazendo com que ele aumente ou diminua dependendo da condição de vento.

Para o mês de março (Figura 33), os maiores transportes no cânion de Japaratuba ocorrem para ventos de Nordeste e Leste, tanto o transporte total quanto em qualquer profundidade analisada. Já os ventos de Sudeste e Sul apresentam menores transportes pois em profundidades menores que 100 e 200 m, respectivamente, seus transportes são negativos, e continuam sendo menores que as outras condições de ventos mesmo quando o transporte passa a ser positivo em maiores profundidades. Já para o mês de julho (Figura 48), os maiores transportes no cânion de Japaratuba ocorrem para ventos de Leste e Sudeste, onde ambos os casos o transporte é negativo em profundidades menores que $200 \mathrm{~m}$, e passam a ser positivos em regiões mais profundas. Ventos de Nordeste também são negativos em regiões mais rasas, mas passam a apresentar transporte positivo abaixo de 300 $\mathrm{m}$, permanecendo com transporte menor que as condições de vento de Leste e Sudeste em maiores profundidades. Em setembro (Figura 63), os maiores transportes ocorrem para ventos de Nordeste e Leste, sendo praticamente os mesmos, seguidos por ventos de Sudeste, que apresenta transporte menor que as outras duas condições de ventos para profundidades maiores que $150 \mathrm{~m}$.

O cânion do São Francisco apresenta transporte negativo, ou seja, o fluxo vindo de região mais profundas em direção ao cânion é maior que o fluxo no sentido 
oposto. No mês de março (Figura 33), os transportes mais negativos ocorrem para ventos de Nordeste e Leste, enquanto no mês de julho (Figura 48), os transportes mais negativos são para ventos de Nordeste, devido a sua diferença maior em relação às outras condições de vento entre 50 e $300 \mathrm{~m}$ de profundidade. Abaixo de $300 \mathrm{~m}$ é possível observar que o transporte chega a ser positivo em todas as condições de vento. Por fim, no mês de setembro (Figura 63), os transportes mais negativos também são para ventos de Nordeste e Leste, com as maiores diferenças entre 50 e $150 \mathrm{~m}$ de profundidade.

Nas simulações considerando o aporte fluvial e sem vento, não foram observadas diferenças significativas entre o cenário com aporte fluvial $(C)$ e 0 cenário sem o aporte (D). Isto foi observado nas figuras ilustrando a temperatura e a salinidade nos dois cânions, na energia cinética, nas velocidades paralelas à costa passando pelas seções perpendiculares à costa, nas velocidades passando pela seção de cada um dos cânions, e no transporte ao longo da coluna d'água em cada cânion. A maior diferença ocorreu para o cânion do São Francisco no mês de julho, quando a adição de aporte fluvial aumentou a intensidade do fluxo em menos de $3 \%$ que na condição sem aporte fluvial. Desta forma, de acordo com as simulações a adição de aporte fluvial não alterou o fluxo nos cânions.

Tendo avaliado essas pequenas diferenças ao adicionar aporte fluvial, também pode-se considerar que não foi possível reproduzir de forma realista a SNB para a região, uma vez que o núcleo apareceu próximo à superfície, e não em subsuperfície, e mais intenso do que o esperado.

Nas simulações considerando ventos variáveis com o tempo, pudemos observar que o mês de março foi o único mês que apresentou períodos em que o ângulo de incidência dos ventos varia entre $45^{\circ}$ e $90^{\circ}$ (entre ventos de Nordeste e de Leste). Durante quase todos os períodos analisados, os ventos estão entre $90^{\circ} \mathrm{e}$ $135^{\circ}$ (entre ventos de Leste e de Sudeste).

No período de ventos entre Nordeste e Leste, em março, o transporte no cânion do São Francisco é o mais negativo no mês, ou seja, o fluxo de água vindo de direções mais profundas em direção ao cânion é maior que o fluxo na direção oposta. Já para situações de ventos entre Leste e Sudeste, há uma variabilidade dependendo do ângulo de incidência e a intensidade do vento paralelo à costa. 
Nos três meses analisados, o transporte mais intenso no cânion de Japaratuba ocorre na situação em que o vento está entre Leste e Sudeste e com alta intensidade na componente paralela à costa. Apenas no mês de julho ocorrem períodos em que o transporte no cânion de Japaratuba é negativo, ou seja, fluxo vindo de regiões mais profundas em direção ao cânion. Essa inversão no sentido preferencial ocorreu para ventos de Sudeste de baixa intensidade na componente paralela à costa.

Com relação ao cânion do Sâo Francisco, o transporte mais negativo ocorre para ventos de Sudeste em julho, e para ventos entre Leste e Sudeste para os meses de março e setembro, em todas as condições com a componente paralela à costa de baixa intensidade. O transporte no cânion do São Francisco passa a ser positivo em dois períodos, em julho e setembro, em condição de vento de Leste e com alta intensidade da componente paralela a costa.

Uma vez que apenas em um período em março ocorrem ventos de Nordeste, vamos analisar com maior profundidade os resultados para ventos variando entre Leste e Sudeste, e avaliar possíveis causas dos cânion de Japaratuba e do São Francisco apresentarem dinâmica tão diferente entre si.

Considerando apenas ventos entre Leste e Sudeste, o cânion de Japaratuba tem os maiores transportes em sua seção para ventos de Leste intensos, que diminuem conforme aumenta o ângulo de incidência do vento, podendo inverter o sentido do fluxo, passando a apresentar transporte integrado ao longo da coluna d'água negativo para ventos de Sudeste. Já para o cânion do São Francisco, que apresenta predominantemente transporte negativo, o transporte mais intenso ocorre para ventos entre Leste e Sudeste com baixa intensidade da componente paralela à costa, e apresenta fluxos menores, chegando a inverter o sentido e ficando positivo para vento de Leste forte.

Assim, os maiores transportes nos cânions ocorrem para ventos entre Leste e Sudeste, sendo positivo para o cânion de Japaratuba e negativo para o do São Francisco. A atenuação do transporte, chegando a inverter o sentido do fluxo, ocorre para vento de Sudeste para o cânion de Japaratuba, e para vento de Leste para o cânion do São Francisco. Assim, quanto menor o ângulo de incidência do vento, maior será o transporte positivo no cânion de Japaratuba, enquanto que, para o cânion do São Francisco, quanto maior o ângulo de incidência do vento, maior será 
o transporte negativo na seção do cânion. A Figura 83 ilustra cada condição de vento, e os respectivos transportes máximos e mínimos nos cânions.

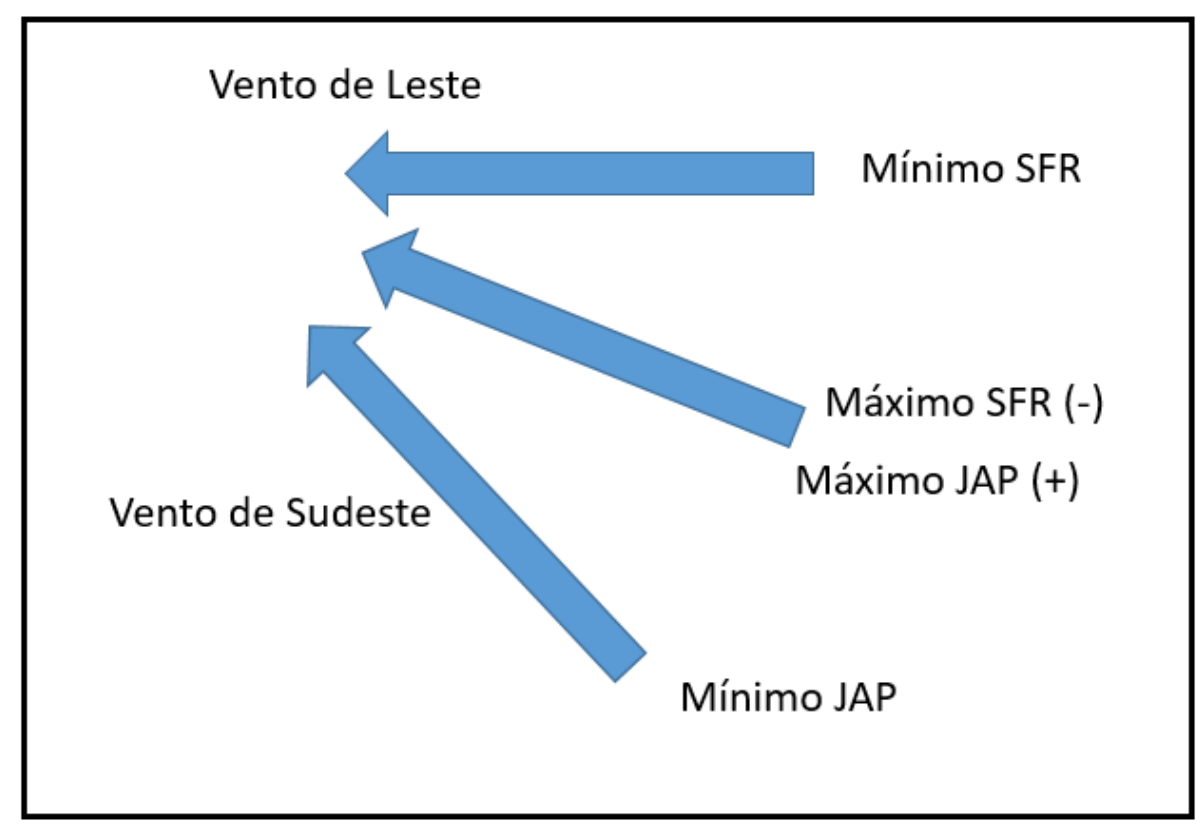

Figura 83 - Condições de vento entre Leste e Sudeste, relacionados com transportes máximo e mínimos para os cânions de Japaratuba (JAP) e do São Francisco (SFR), sendo positivo (+) para o cânion de Japaratuba, e negativo (-) para o cânion do São Francisco.

Uma vez que os cânions apresentam comportamentos praticamente opostos, as forçantes que são mais importantes em cada um deles devem ser diferentes e opostas.

Segundo a convenção de Allen \& Madron (2009), fluxos ao longo do talude que sejam na mesma direção de propagação das ondas de Kelvin, são chamados de fluxos "along-slope" positivos (Figura 4 sup. dir. e Figura 4 inf. dir.), e privilegiam subsidência, ou seja, transporte perpendicular à costa positivo, enquanto que fluxos na direção oposta são chamadas de fluxos "along-slope" negativos (Figura 4 sup. esq. e Figura 4 inf. esq.), e privilegiam ressurgência, ou seja, transporte perpendicular à costa negativo nos cânions. Para o Hemisfério Sul, as ondas de Kelvin propagam com a costa à esquerda do fluxo, que é o caso da SNB, que flui para Nordeste, com a costa à sua esquerda, ou seja, ela é um caso de fluxo "alongslope" positivo, e deve privilegiar transporte positivo.

Uma vez que o transporte no cânion de Japaratuba é predominantemente positivo, e a SNB privilegia o fluxo nesse mesmo sentido, podemos dizer que a SNB 
é uma forçante importante para a circulação em torno do cânion. Já o cânion do São Francisco apresenta comportamento contrário, com transporte predominantemente negativo, ou seja, a forçante mais importante não deve ser a SNB, e sim, alguma que haja no sentido oposto. Uma possível candidata a ser essa forçante são as correntes que ocorrem na PC e ao longo do talude, que fluem para Sudeste, ou seja, ao contrário do sentido da propagação das Ondas de Kelvin, e portanto, fluxo "alongslope" negativo.

Vamos avaliar 3 possíveis cenários com relação a influência da SNB e das correntes na PC, representados na Figura 84. Por ser fluxo "along-slope" positivo, a SNB gera transporte positivo nos cânions, enquanto que as correntes na PC são fluxo "along-slope" negativo e, portanto, geram transporte negativo nos cânions (Figura 84A). Ao somar o efeito das duas forçantes nesse primeiro cenário, a resultante será o somatório do balanço de forças ao longo da profundidade dos cânions. Se a SNB causar um efeito maior no cânion de Japaratuba, e as correntes na PC causarem efeito maior no cânion do Sâo Francisco, o transporte será positivo para o cânion de Japaratuba, e negativo para o cânion do São Francisco (Figura 84A).

Um segundo cenário, em que a SNB é atenuada e as correntes na PC são intensificadas e apresentadas na Figura 84C. Nesse caso, irá diminuir o transporte positivo causado pela SNB e aumentará o transporte negativo causado pelas correntes na PC. O resultado será a ateunação do transporte positivo no cânion de Japaratuba, ou até inverter o sentido do fluxo, tornando-se negativo (Figura 84D), e a intensificação do transporte negativo no cânion do São Francisco.

Por fim, um terceiro cenário (Figura 84E), em que a SNB é intensificada e as correntes da PC são atenuadas. Como efeito, irá aumentar o transporte positivo nos cânions devido ao efeito causado pela SNB, e diminuir o transporte negativo causado pelas correntes na PC. Somando as duas resultantes (Figura 84F), o transporte positivo no cânion de Japaratuba será intensificado, enquanto que o transporte negativo no cânion do São Francisco será atenuado, ou terá seu sentido invertido. 


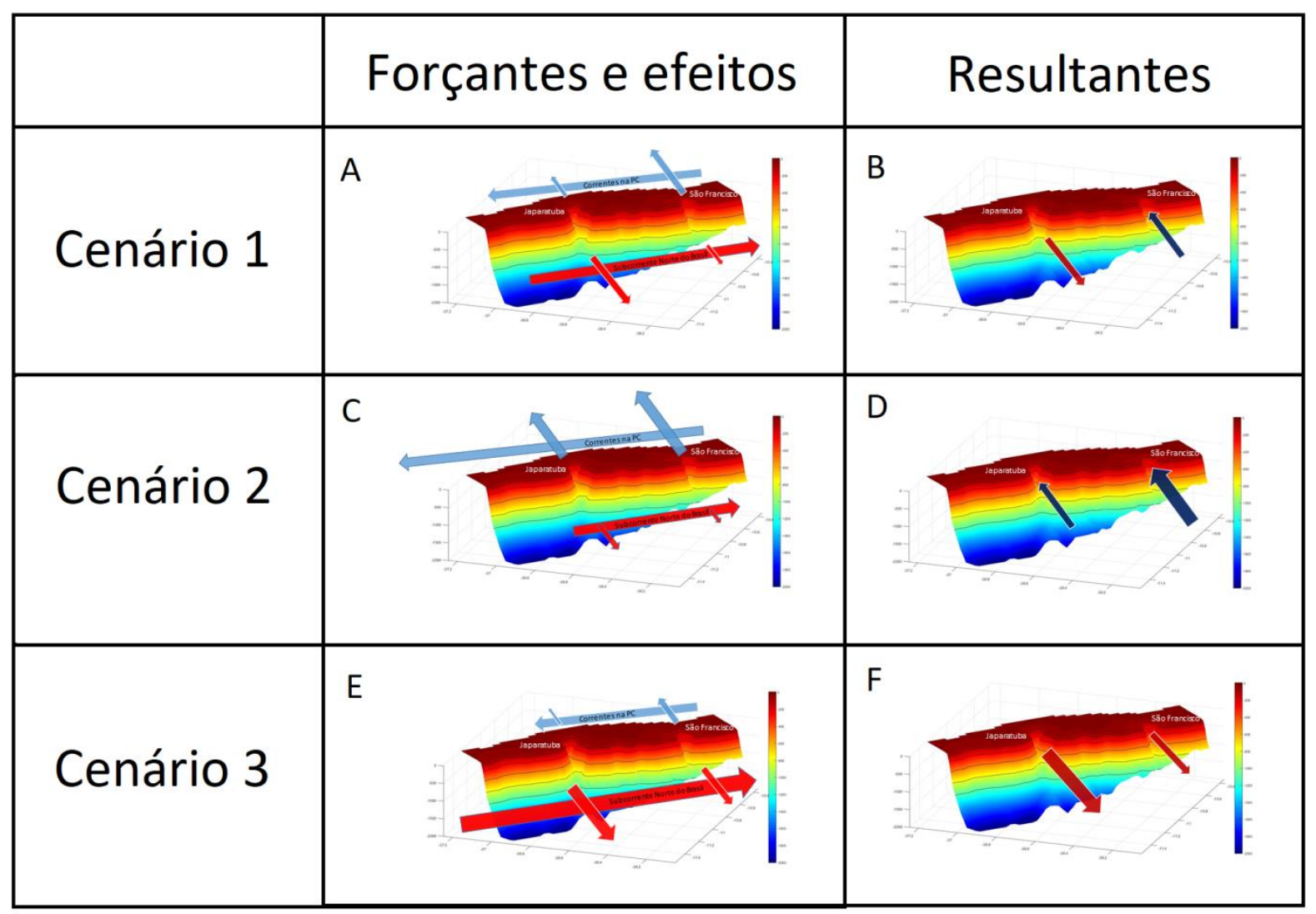

Figura 84 - Diferentes cenários para a SNB e correntes na PC e seus respectivos efeitos nos cânions de Japaratuba e do São Francisco

Dessa forma, é possível explicar como os dois cânions apresentam comportamento na circulação praticamente opostos nas mesmas condições de vento. Para isso, a SNB deve apresentar maior influência no cânion de Japaratuba, e as correntes na PC devem causar maior influência no cânion do São Francisco.

Uma possível explicação para essa diferença de influências da SNB e das correntes na PC nos cânions é o sentido da circulação, em que cada fluxo aproxima primeiro de um dos cânions, para depois chegar ao outro. As correntes na PC fluem para Sudoeste, e, portanto, chegam primeiro no cânion do São Francisco, e posteriormente chega ao cânion de Japaratuba. Ao se aproximar do cânion do São Francisco, parte do fluxo é desviado devido à presença do cânion, com a mudança da profundidade local alterando a vorticidade. Uma vez que parte do fluxo é desviado na direção perpendicular à costa, ao longo do eixo do cânion, o fluxo que seguirá para o cânion de Japaratuba será menor, e assim, sua influência será menor que no cânion do São Francisco. Já para a SNB, que apresenta fluxo para Nordeste, atinge inicialmente o cânion de Japaratuba, parte do fluxo é desviado pela mudança 
de profundidade ao aproximar do cânion, e um fluxo menor segue para o cânion do São Francisco. Assim, a influência da SNB será menor no cânion do São Francisco do que no cânion de Japaratuba.

Assim, a hipótese científica do trabalho, de que a presença dos cânions de Japaratuba e do São Francisco afeta a circulação e o fluxo de volume entre oceano aberto e a plataforma continental é válida, uma vez que cada cânion apresentou circulação e transporte diferentes, e a presença dos cânions permite o fluxo mais intenso perpendicularmente à costa, o que normalmente não acorre, sendo predominantemente paralelos à costa, seguindo isóbatas. Os objetivos também foram atingidos, ao se obter o fluxo de volume nos cânions nas diferentes condições de ventos, para os 3 meses simulados, com ventos constantes no tempo, ventos variáveis, presença e ausência de aporte fluvial, e na ausência de vento. Também foram determinados quais configurações favorecem ressurgência ou subsidência, ou seja, quais apresentam transporte negativo ou positivo, respectivamente, tanto para ventos constantes quanto para ventos variáveis. 


\section{5 - Conclusão}

Através das diversas simulações foi possível gerar a SNB nos casos A, B e E, em que os campos de $T$ e $S$ são mantidos constantes ao longo do tempo, com núcleo ocorrendo em subsuperfície, entre 100 e $400 \mathrm{~m}$ de profundidade, afastado da costa, e com intensidade máxima variando de 0,8 a 1,2 $\mathrm{m} \cdot \mathrm{s}^{-1}$. Os meses de junho e setembro apresentaram campos de $T$ e $S$ semelhantes, e assim como no mês de março, foi possível verificar a presença das massas d'água características da região, sendo elas a AT, ACAS e AIA.

A ação dos ventos altera consideravelmente a circulação, em especial na região dos cânion de Japaratuba e do São Francisco. Dependendo da condição de vento, ocorre aumento ou diminuição da intensidade do transporte perpendicular à costa na seção dos cânions. O cânion de Japaratuba apresentou predomínio de transporte perpendicular à costa positivo, ou seja, o fluxo de água do cânion indo para regiões mais profundas é maior que o fluxo na direção oposta, enquanto que o cânion do São Francisco apresentou predomínio de fluxos negativos.

Ao adicionar a ação dos ventos constantes como forçante (simulações do tipo B), foi observado que ventos de Nordeste e de Leste intensificaram o fluxo na seção de cada cânion, ficando mais positivo no cânion de Japaratuba, e mais negativo no cânion do São Francisco. Já ventos de Sudeste e Sul atenuaram os fluxos, ficando menor ou até negativo no cânion de Japaratuba, e ficando menos negativo ou até positivo no cânion do São Francisco. Ventos de Nordeste e Leste aumentaram o fluxo negativo em regiões mais próximas à superfície (até $300 \mathrm{~m}$ ) no cânion de Japaratuba, porém, ao integrar na coluna d'água, o transporte total aumentou, pois em regiões mais profundas o transporte se tornou mais positivo.

Nas simulações com ventos variáveis (simulações do tipo $E$ ), foi verificado que o transporte mais intenso no cânion de Japaratuba se deu para ventos entre Leste e Sudeste intensos, enquanto que ventos de Sudeste atenuam, ou até invertem o sentido predominante do fluxo.

Nos meses de julho e setembro não houve a presença de ventos de Nordeste, e portanto, não foi possível avaliar a ação dessa condição de vento nesses dois meses. Apenas em março, quando o transporte negativo no cânion do Sâo Francisco se mostrou mais intenso no período que foi possível avaliar. Fora o 
período em que houve ventos de Nordeste, o transporte mais intenso para o cânion do São Francisco se deu para vento entre Leste e Sudeste, enquanto que o transporte mais ameno se deu para vento de Leste, chegando até a inverter o sentido do fluxo e ficando positivo.

Uma possível explicação para os cânions apresentarem transportes opostos para as mesmas condições de vento é que o cânion de Japaratuba sofre maior influência da SNB, enquanto que o cânion do Sâo Francisco sofre maior influência das correntes na PC, que apresentam fluxo na direção oposta à SNB. Como a SNB flui para Nordeste, com a costa à sua esquerda, ele apresenta fluxo "along-slope" positivo, e gera transporte positivo nos cânions, uma vez que flui na mesma direção das ondas de Kelvin. Já as correntes na PC fluem para Sudoeste, e portanto, apresentam fluxo "along-slope" negativo, gerando transporte negativo nos cânions. A somatória do efeito dessas duas forçantes é responsável pelo comportamento diferenciado entre os cânions, que pode ser explicado pela direção de circulação das correntes em PC e da SNB.

Nas simulações com aporte fluvial (experimentos $C$ e D) não foi possível gerar a SNB, mas sim uma Corrente de Contorno Oeste com núcleo próximo à superfície, e máximo de $1,5 \mathrm{~m} \cdot \mathrm{s}^{-1}$. Os experimentos $C$ e $D$ apresentaram resultados quase idênticos, com menos de $3 \%$ de diferenças nos transportes. 


\section{6 - Referências}

Ahumada-Sempoal, MA, Flexas, MM, Bernardello, R, Bahamon, N, Cruzado, A, ReyesHernández, C. Shelf-slope exchanges and particle dispersion in Blanes submarine canyon (NW Mediterranean Sea): A numerical study. Continental Shelf Research. 2015 Oct;109:3545.

Ardhuin, F, Pinot, JM, Tintoré, J. Numerical study of the circulation in a steep canyon off the Catalan coast (western mediterranean). Journal of Geophysical Research 1999 May; 104: 11115-35.

Allen, SE. Topographically generated, subinertial flows within a finite length canyon. Journal of Physical Oceanography. 1996 Feb;26:1608-32.

Allen, SE, Vindeirinho, C., Thomson, RE, Foreman, MGG, Mackas, DL. Physical and biological processes over a submarine canyon during an upwelling event. Canadian. Journal of Fisheries and Aquatic Sciences. 2007;58:671-84.

Allen, SE, Madron, XD. A review of the role of submarine canyons in deep-ocean exchange with the shelf. Ocean Science. 2009 Dec;5:607-20.

Blumberg, AF, Khan, LA, John, JPS. Three-dimensional hydrodynamic model of new york harbor region. Journal of Hydraulic Engineering. American Society of Civil Engineers. 1999 Aug; 125(8):799-815.

Blumberg, AF, Mellor, GL. A description of a three-dimensional coastal ocean circulation model. Three-dimensional coastal ocean models. Wiley Online Library. 1987;1-16.

Bosley, KL, Lavelle, JW, Brodeur, RD, Wakefield, WW, Emmett, RL, Baker, ET, Rehmke, KM. Biological and physical processes in and around Astoria submarine Canyon, Oregon, USA. Journal of Marine Systems. 2004 Jul;50:21-37.

Coutinho, PN. Geologia marinha da plataforma continental Alagoas-Sergipe [tese de livredocência]. Recife: Universidade Federal de Pernambuco; 1976. 119p.

Emery, WJ. Water types and water masses. Ocean circulation. 2003;1556-67. 
Freeland, HJ, Denman, KL. A topographically controlled upwelling center off southern Vancouver Island. Journal of Marine Research. 1982;40:1069-92.

Goes, M, Molinari, R, da Silveira, ICA, Wainer, I. Retroflections of the north brazil current during february 2002. Deep Sea Research Part I: Oceanographic Research Papers. 2005 Apr;2(4):647-67.

Granata, TC, Vidondo, B, Duarte, CM, Satta, MP, Garcia, M. Hydrodynamics and particle transport associated with a submarine canyon off Blanes (Spain), NW Mediterranean Sea. Continental Shelf Research. 1999;19:1249-63.

Hamilton, P, Speer, K, Snyder, R, Wienders, N, Leben, RR. Shelf break exchange events near the De Soto canyon. Continental Shelf Research. 2015 Nov;110:25-38.

Hickey, B, Baker, E, Kachel, N. Suspended particle movement in and around Quinault submarine canyon. Marine Geology. 1986;71:35-83.

Hickey, BM. The response of a steep-sided, narrow canyon to time-variable wind forcing. Journal of Physical Oceanography . 1997 May; 27:697-726.

Jordi, A, Orfila, A, Basterretxea, J. Shelf-slope exchanges by frontal variability in a steep submarine canyon. Progress in Oceanography. 2005 May;66:120-41

Klinck, JM. The Influence of a Narrow Transverse Canyon on Initially Geostrophic Flow. Journal of Geophysical Research. 1988 Jan;93(C1):509-15.

Klinck, JM. Circulation near submarine canyons: a modelling study. Journal of Geophysical Research. 1996 Jan;101(C1):1211-33.

Lellouche JM, Legalloudec O, Regnier C, Levier B, Greinier E, Drevillon M. For Global Sea Physical Analysis and Forecasting Product. Product User Manual. 2016. GLOBAL_ANALYSIS_FORECAST_PHYS_001_024.

http://resources.marine.copernicus.eu/documents/QUID/CMEMS-GLO-QUID-001-024.pdf Acessado em 14 de Abril de 2019. 
Madron, XD. Hydrography and nepheloid structures in the Grand- Rhone canyon. Continental Shelf Research. 1994;14(5):457-77.

Manual do usuário Stevens ECOM. 2010 Oct. 193 p. Apêndice II.

Molinari, RL. Observations of eastward currents in the tropical South Atlantic Ocean: 19781980. Journal of Geophysical Research. 1982 Nov;87(C12): 9.707-14.

National Centers for Environmental Prediction/National Weather Service/NOAAUU.S. Department of Commerce. 1994, updated monthly. NCEP/NCAR Global Reanalysis Products, 1948-continuing. Research Data Archive at the National Center for Atmospheric Research, Computational and Information Systems Laboratory. http://rda.ucar.edu/datasets/ds090.0/. Acessado em 14 de Abril de 2019.

Peterson, RG, Stramma, L. Upper-level circulation in the South Atlantic Ocean. Progress in oceanography. 1991;26(1):1-73.

Palanques, A, García-Ladona, E., Gomis, D., et al. General patterns of circulation, sediment fluxes and ecology of the Palamós (La Fonera) submarine canyon, northwestern Mediterranean. Progress in Oceanography. 2005 Jun;66:89-119.

Parente, F.T.F., 2016. Hidrodinamica da Plataforma Continental da bacia Sergipe-Alagoas (Dissertação de Mestrado, Universidade de Sao Paulo).

Rennie, SJ, Pattiaratchi, CB, McCauley, RD. Numerical simulation of the circulation within the Perth Submarine Canyon, Western Australia. Continental Shelf Research. 2009;29:2020-36

She, J, Klinck, JM. Flow near submarine canyons driven by constant winds. Journal of Geophysical Research. 2000;105(C12):28671-94.

Silva, C, Clarke, RT. Análise estatística de chuvas intensas na bacia do rio São Francisco. Revista Brasileira de Meteorologia. 2004 Apr;19(3):265-72.

Silveira, ICA., Miranda, LB, Brown, WS. On the origins of the north brazil current. Journal of Geophysical Research. 1994 Nov;99(C11):22.501-12. 
Skliris, N, Hecq, JH, Djenidi, S. Water fluxes at an ocean margin in the presence of a submarine canyon. Journal of Marine Systems. 2002 Apr;32(1-3):239-51.

Skliris, N, Lacroix, G, Djenidi, S. Effects of extreme meteorological conditions on coastal dynamics near a submarine canyon. Continental Shelf Research. 2004 Feb; 24: 1033-45.

Sobarzo, M, Figueroa, M, Djurfeldt, L. Upwelling of subsurface water into the rim of the Biobío submarine canyon as a response to surface winds. Continental Shelf Research. 2001;21:279-99.

Song, YT, Chao, Y. A theoretical study of topographic effects on coastal upwelling and crossshore exchange. Ocean Modelling. 2004;6:151-76.

Soutelino, RG. Caracterização da estrutura baroclínica do sistema de correntes de contorno Oeste ao largo da costa leste brasileira [monografia]. Rio de Janeiro: Universidade Estadual do Rio de Janeiro; 2005. 50p.

Stramma, L. Geostrophic transport of the south equatorial current in the Atlantic. Journal of Marine Research. 1991 May; 49(2):281-94.

Stramma, L, Fischer, J., Reppin, J. The north brazil undercurrent. Deep-Sea Research Part I - Oceanographic Research Papers. 1995 May;42(5):773-95.

Summerhayes, CP, Fainstein, R, Ellis, JP. Continental margin off Sergipe and Alagoas, northeastern Brazil: a reconnaissance geophysical study of morphology and structure. Marine Geology. 1976 Apr;20(4):345-61. 